FACULDADE DE FILOSOFIA, LETRAS E CIÊNCIAS HUMANAS

\title{
DEPARTAMENTO DE GEOGRAFIA
}

\section{PROGRAMA DE PÓS-GRADUACẼO EM GEOGRAFIA HUMANA}

Téenicas de Geoprocessamento aplicadas na. Análise do

Qbo da Perra no Manicipio de OPilar do Pul - OSOP

Eduardo Reis Rosa

Dissertação apresentada ao Programa de PósGraduação em Geografia Humana, do Departamento de Geografia da Faculdade de Filosofia, Letras e Ciências Humanas da Universidade de São Paulo, para obtenção do título de Mestre em Geografia Humana.

ORIENTADOR: Prof. Dr. Mário de Biasi

Julho / 2006 


\section{AGRADECIMENTOS}

Ao Prof. Dr. Mário de Biasi, pela confiança ao aceitar-me como mais um de seus orientandos, pela orientação e apoio incondicional em todos os momentos e pela amizade demonstrada.

A meu pai, Prof. Dr. Flavio Sammarco Rosa, pela orientação de todas as horas, pelas sugestões e recomendações no projeto de pesquisa.

Ao Prof. Dr. Jurandyr Luciano Sanches Ross e Prof. Dr. Ailton Luchiari, membros da banca de exame de qualificação, pelas críticas e recomendações que contribuíram para o aprimoramento deste trabalho.

A minha mãe, irmãos, namorada, amigos e parceiros de trabalho pelo apoio, compreensão e companheirismo.

Pelas informações fornecidas, a Prefeitura de Pilar do Sul, a quem cabe o desafio de implementar as propostas aqui apresentadas.

A muitos que deixei de citar e que ,de alguma forma, ajudaram na elaboração deste trabalho, fornecendo-me material de pesquisa ou dando sugestões valiosas.

Pelo apoio recebido, meu agradecimento sincero. 


\section{RESUMO}

O trabalho tem como principal objetivo a elaboração de uma proposta de Zoneamento Agroecológico do Município de Pilar do Sul, São Paulo.

O Zoneamento é definido a partir do cruzamento de informações do meio físico do uso e ocupação da terra e de legislação, com a utilização dos recursos de Sistemas de Informações Geográficas.

A delimitação de unidades ambientais visa dar apoio ao planejamento e à adoção de práticas de manejo e de conservação do solo de acordo com a aptidão agrícola e com as limitações naturais.

Finalmente, ressalta a importância do ordenamento territorial como meio de proteção dos recursos hídricos, de manutenção das áreas de preservação permanente e das Matas e como garantia de aumento do potencial produtivo das áreas agrícolas, resultando em melhoria do ambiente e em melhor qualidade de vida dos habitantes do Município.

Palavras-chave: Zoneamento Agroecológico; Pilar do Sul; Geoprocessamento; Uso da Terra, Planejamento Ambiental. 


\section{ABSTRACT}

The main purpose of the work is to elaborate an Agroecologic Zoning proposition for Pilar do Sul, a municipal district in the state of São Paulo.

The Zoning is defined by the crossing of information about the physical environment, the usage and occupancy of land and legislation, making use of Geographic Information System resources.

The environmental units delimitation aims to give support for the planning and the adoption of handling and soil conservation practices, according to agricultural aptness and natural limitations.

Finally, it emphasizes the importance of territorial arrangement as a way of preserving water resources, maintaining permanent preservation areas and forests, and as a guarantee for the increasing of the productive potencial in agricultural regions. Once established, these items are responsible for the environmental improvement and better quality of life for the inhabitants of the district.

Keywords: Agroecologic Zonning, Pilar do Sul, Geoprocessing, Land Use, Environmental planning. 
ÍNDICE

1. Introdução. .9

2. Objetivos e Desafios. 17

3. Procedimentos Metodológicos 20

4. Caracterização da Área de Estudo.

4.1. Aspectos Físico-Naturais. .44

4.2. Caracterização Sócio-econômica. 68

5. Potencial de Degradação Ambiental. .87

6. Capacidade de Uso da Terra. .94

6.1. Fatores Limitantes .104

7. Zoneamento Agroecológico. 106

8. Considerações Finais.

9. Referências Bibliográficas. 


\section{ÍNDICE DE FOTOS}

pg

1. Foto 1 - Cidade de Pilar do Sul.........................................................................

2. Foto 2 - Relevo do Planalto Atlântico...................................................................44

3. Foto 3 - Relevo da Depressão Periférica...........................................................50

4. Foto 4 - Silvicultura e Remanescentes de Mata Atlântica....................................66

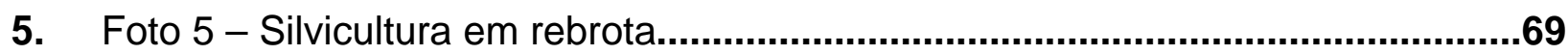

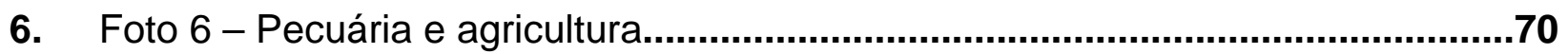

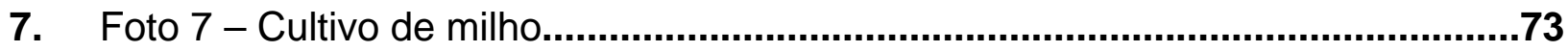

8. Foto 8 - Agricultura anual com Pivô - Central........................................................74

9. Foto 9 - Cultivo de uva Itália em parreiras........................................................75

10. Foto 10 - Cultivo de Laranja...................................................................................

11. Foto 11 - Cultivo de Maracujá...............................................................................76

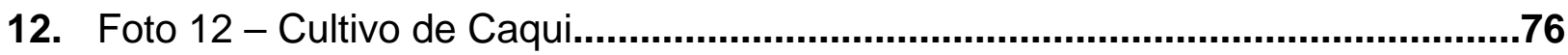

13. Foto 13 - Práticas de Cultivo em Estufa.............................................................77

14. Foto 14 - Práticas de Cultivo com Sombrite........................................................77

15. Foto 15 - Práticas de Cultivo em Estufa...............................................................77

16. Foto 16 - Horticultura com prática de irrigação por aspersão..................................79

17. Foto 17 - Área de Pastagem em bom estado de conservação..............................81

18. Foto 18 - Área de Pastagem com curva de nível...................................................82

19. Foto 19 - Área de Pastagem degradada................................................................82

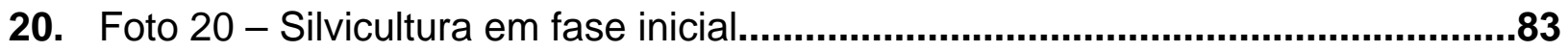

21. Foto 21 - Silvicultura em fase avançada............................................................84

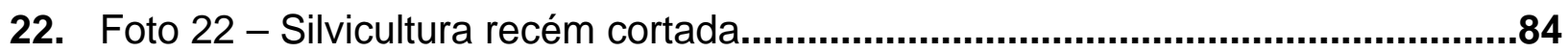




\section{ÍNDICE DE FIGURAS}

1. Figura 1 - Mapa de Localização.......................................................................15

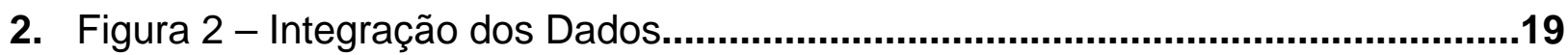

3. Figura 3 - Mapa Pedológico do Estado de São Paulo..............................................26

4. Figura 4 - Mapa Geomorfológico do Estado de São Paulo.....................................28

5. Figura 5 - Carta de Utilização da Terra do Estado de São Paulo.............................29

6. Figura 6 - Visualização tridimensional de fotografia aérea......................................30

7. Figura 7 - Visualização tridimensional da classificação de Uso da Terra.................31

8. Figura 8 - Mapa de Capacidade de Uso das Terras do Estado de São Paulo.........37

9. Figura 9 - Metodologia de Trabalho....................................................................

10. Figura 10 - Mapa Topográfico................................................................................46

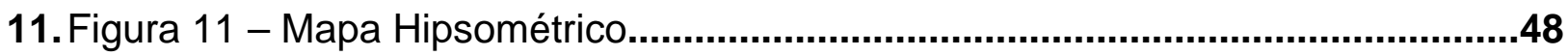

12. Figura 12 - Visualização tridimensional do terreno com fotografia aérea.................51

13. Figura 13 - Classes Clinográficas sobrepostas à fotografia aérea............................52

14. Figura 14 - Mapa Clinográfico................................................................................53

15. Figura 15 - Medidas Topográficas na Depressão Periférica.....................................55

16. Figura 16 - Visualização Tridimensional da Depressão Periférica...........................55

17. Figura 17 - Medidas Topográficas no Planalto Atlântico...........................................56

18. Figura 18 - Visualização Tridimensional do Planalto Atlântico...................................56

19. Figura 19 - Mapa Geomorfológico...........................................................................59

20. Figura 20 - Pluviosidade Média Mensal: Período 1973 - 1997...............................63

21. Figura 21 - Pluviosidade Padrão: Ano de 1977....................................................63

22. Figura 22 - Visualização Tridimensional de Áreas de Mata Ciliar............................65 
23. Figura 23 - Área ocupada com Culturas Anuais..................................................72

24. Figura 24 - Volume de Produção das Culturas Anuais............................................72

25. Figura 25 - Área Cultivada com Fruticultura.......................................................78

26. Figura 26 - Volume de Produção da Fruticultura......................................................78

27. Figura 27 - Área Cultivada com Horticultura.........................................................80

28. Figura 28 - Volume de Produção de Horticultura....................................................80

29. Figura 29 - Imagem de satélite e fotografia aérea mostrando o uso da terra..........85

30. Figura 30 - Mapa de Uso e Cobertura da Terra.................................................86

31. Figura 31 - Área de solo exposto.................................................................91

32. Figura 32 - Mapa de Potencial de Degradação Ambiental.....................................93

33. Figura 33 - Mapa de Classes de Capacidade de Uso da Terra............................105

34. Figura 34 - Vizualização tridimensional do mapa de Zoneamento..........................108

35. Figura 35 - Mapa de Zoneamento Agroecológico............................................110 
Técnicas de Geoprocessamento aplicadas na análise do Uso da Terra no Município de Pilar do Sul - SP

\section{Introdução}

O Município de Pilar do Sul, situado na região de Sorocaba, foi escolhido como área de pesquisa por ter condições ambientais e de uso da terra bem diversificados. A atividade agropecuária se faz muito presente, apesar do município possuir sérias limitações proporcionadas pelo relevo acidentado, característico dos contrafortes da Serra de Paranapiacaba. Este cenário é favorável à aplicação de uma metodologia que permite testar as possibilidades de identificação de áreas potencialmente favoráveis ao uso agrícola e áreas onde a natureza é determinante no tipo de uso, levando à necessidade de se preverem e de se estabelecerem limitações de uso e de se identificarem áreas de preservação e proteção ambiental.

O estudo caracteriza o Município, indicando diretrizes para se planejar o desenvolvimento regional e minimizar impactos ambientais nos diversificados tipos de usos da terra. Devido às diferenças ambientais, as áreas possuem recomendações de uso que consideram os aspectos naturais, culturais e sociais.

Pierre George afirma que "Objetivamente falando, o meio ambiente constitui um sistema de relações extremamente complexas, muito sensível às variações de qualquer de seus fatores e desencadeando reações em cadeia. É geralmente definido como sendo um equilíbrio entre um número muito grande de grupos de forças que se compensam umas às outras. Trata-se de uma imagem já excessivamente simplificada, pois os equilíbrios que se estabelecem na natureza e, com ainda maior razão, numa natureza mais ou menos obliterada pelas múltiplas intervenções dos homens, constituem equilíbrios muito frágeis e instáveis" (GEORGE - 1973). 
No caso do Município de Pilar do Sul, o estudo possibilita vislumbrar intervenções na realidade, recomendando e prevendo usos e medidas específicas para determinadas áreas, contribuindo, assim, para garantir à população o uso dos recursos naturais de forma equilibrada e com menor prejuízo ao meio ambiente.

A cartografia digital, os sistemas de informações geográficas e os sistemas de posicionamento global, integrados com as informações que caracterizam geograficamente aspectos naturais e sociais, vêm auxiliar e facilitar as análises dos diferentes geofatores que atuam e compõem 0 ambiente. $O$ uso do geoprocessamento para análise ambiental deve conter uma metodologia de integração de dados que estabeleça a contribuição de cada variável geográfica. A geração de múltiplos mapeamentos temáticos, uns com características analíticas e outros, de síntese, é a base para a integração de dados.

As técnicas cartográficas auxiliadas pelo geoprocessamento oferecem os recursos necessários para o levantamento dos dados e a sistematização das informações, analisadas espacialmente, integradas e correlacionadas, resultando no produto final, a síntese das informações levantadas.

Os Sistemas de Informações Geográficas (SIG) possibilitam diagnosticar e caracterizar a área de estudo através de cruzamentos e manipulação dos dados do meio físico e sócio-econômico. O Mapa de Zoneamento Agroecológico é a síntese de todas as informações e dados levantados no desenvolvimento do projeto de pesquisa.

O planejamento do uso da terra tem utilizado classificações técnicas interpretativas como "Capacidade de Uso das Terras" (LEPSCH - 1983), que adota práticas de conservação do uso do solo; a "Aptidão Agrícola" (RAMALHO et al 1978), que regionaliza diferentes tipos de utilização agrícola; e os Zoneamentos Ecológicos e Ambientais, que reordenam a implantação de culturas e estabelecem tipos de uso e cobertura da terra que melhor se adaptam às condições locais.

$\mathrm{Na}$ tentativa de se adequar às variações ambientais regionais encontradas em Pilar do Sul, o sistema de classificação das terras, aqui proposto, pondera variáveis ou classes que contribuem para a caracterização da área de estudo, propondo 
práticas de uso e manejo agrícola, visando ao desenvolvimento social e à conservação ambiental.

Os princípios utilizados e analisados neste projeto de pesquisa foram selecionados e extraídos dos propostos e citados em bibliografias que, em decorrência da vida acadêmica, puderam ser estudadas.

O manejo conservacionista do solo agrícola visa à preservação de áreas com capacidade de uso restrito. O emprego de técnicas agrícolas adequadas contribui para a conservação dos solos e para a manutenção das condições ambientais, seja no desenvolvimento da atividade agrícola ou na manutenção de áreas de preservação.

Historicamente, tem-se estabelecido uma dicotomia entre o homem e a natureza. O conhecimento e as ciências têm-se organizado a partir da divisão de ciências naturais e ciências humanas. A própria Geografia apresenta-se dividida nas duas grandes disciplinas: Geografia Física e Geografia Humana. No entanto, o entendimento do espaço geográfico leva, necessariamente, à análise integrada da natureza e da sociedade, bem como da relação que se estabelece entre elas (GONÇALVES - 1989).

A natureza e o próprio solo agrícola como meio de produção têm limites originados das suas condições naturais, definindo características de estrutura física, de fertilidade e de necessidade de mão-de-obra para sua utilização num determinado contexto tecnológico. É comum a legislação criada pelo próprio homem limitar a utilização dos recursos naturais, mas ao lado da fiscalização e do controle, é preciso conscientização, orientação e presença técnica para que, de fato, produtores rurais melhor utilizem sua terra.

Embora a ciência e a técnica ofereçam os subsídios para se explorarem os recursos naturais, chegando a modelar o espaço geográfico, é necessário tomar consciência de que ele oferece limites e seus recursos são esgotáveis, não sendo possível usá-los de forma indevida ou irresponsável.

O uso da terra de forma incorreta, seja na zona urbana ou na zona rural, é devido, em grande parte, à falta de informação. A conservação e preservação dos 
recursos naturais são fundamentais para a manutenção de espécies de fauna e flora que ainda restam. A orientação quanto à diminuição de qualquer tipo de processo poluente e degradante é de fundamental importância para que se consiga uma evolução social e cultural de forma a garantir, no futuro, melhores condições de vida que as atuais.

A relação homem-solo é, acima de tudo, uma questão ambiental e a Geografia fornece o apoio necessário para se analisar e entender essa relação. Segundo as palavras de Pierre George, o objeto da Geografia “... é exatamente o estudo de todas as formas de relações recíprocas existentes entre as coletividades humanas e seu envoltório espacial concreto" (GEORGE - 1973).

A degradação ambiental gera processos erosivos que se manifestam de vários modos, tornando os solos menos produtivos e, o ambiente, desequilibrado. $O$ controle da erosão é de fundamental importância no estabelecimento de qualquer tipo de uso da terra, seja ele rural ou urbano.

As condições naturais, associadas ao manejo inadequado, podem acelerar o processo de degradação. Encostas desprotegidas de vegetação, descontinuidades litológicas e pedológicas, encostas íngremes, são condições naturais de risco que devem ser levadas em consideração para o planejamento da ocupação e uso humano e no manejo do solo para diferentes fins. Nos ambientes agrícolas, é necessária a adoção de uma política agrícola que contemple a manutenção ou o aumento do potencial produtivo das terras.

Os potenciais naturais do ambiente devem ser respeitados e explorados. $O$ desmatamento indiscriminado de áreas frágeis para fins agrícolas acaba por degradar o ambiente. O cultivo sem o emprego de adequadas práticas de manejo leva à ocorrência de impactos físico-naturais e sociais: ao mesmo tempo em que se degrada a vegetação, o solo e os recursos hídricos, ocorre um prejuízo social, comprometendo-se a qualidade de vida, por conseqüência de um produto agrícola de baixa qualidade, juntamente com baixas produtividades.

A Agronomia fornece o apoio de técnicas e práticas de conservação e manejo do solo, tanto para a implantação de culturas como para recomposição da 
vegetação ou ainda para recuperação de áreas degradadas, minimizando fontes poluidoras e degradantes do ambiente.

A interdisciplinaridade entre a Agronomia e a Geografia oferece subsídios para analisar e interpretar as relações relevantes no espaço geográfico, especialmente no âmbito agrário. As atividades agrícolas provocam grandes mudanças no aspecto natural do ambiente por conseqüência da intervenção humana, criando amplos espaços antropizados.

Vale citar a colocação de AB'SABER (1969), ao comentar as possibilidades de conflito e sobreposições entre as diversas ciências: "Mais importante do que os conflitos, porém, é a ratificação da idéia fértil, de que os geógrafos têm a responsabilidade de investigar a posição dos agrupamentos humanos num espaço de organização dupla: uma organização natural, herdada dos processos fisiográficos e ecológicos, e, uma organização imposta pela história das construções humanas no espaço geográfico, que é o próprio somatório das inúmeras implantações realizadas pelos agrupamentos humanos que se sucederam no tempo, construindo coisas e organizando espaços em uma determinada parcela do território."

A pesquisa acadêmica auxilia na elaboração de metodologias que ajudam a compreender as relações que a sociedade estabelece com o ambiente. A definição de áreas onde as atividades agrícolas são favorecidas e de áreas que devem ser protegidas, associada aos conhecimentos agronômicos de técnicas de conservação do solo, minimiza os impactos ambientais, propicia maior produtividade nos campos de cultura e conservação dos recursos naturais. Devido à complexidade de fatores envolvidos nos estudos ambientais, a utilização de geotecnologias é de fundamental importância na integração de dados e na possibilidade de atualização de fatores dinâmicos.

No caso de Pilar do Sul, ocorre um exemplo de determinismo geográfico, onde a forte influência da estrutura geológica e uma marcante morfologia do relevo orientam as atividades socioeconômicas, que, conseqüentemente, condicionam as formas de utilização da terra. O Projeto de Pesquisa pretende apresentar uma 
síntese das relações entre o meio físico e a ocupação humana, agrupando áreas através de uma análise das diferentes condições dos fatores e variáveis do meio natural e da sócio-economia. Localizada a $150 \mathrm{Km}$ da capital, São Paulo, Pilar do Sul possui um sistema viário bastante significativo, com fácil acesso às cidades de Sarapuí, São Miguel Arcanjo, Itapetininga, Piedade, Tapiraí, Salto de Pirapora e Sorocaba. A população é de 23.948 habitantes, sendo 12.342 homens e 11.606 mulheres. A Figura 1 apresenta o Município de Pilar do Sul e os demais municípios de seu entorno: 


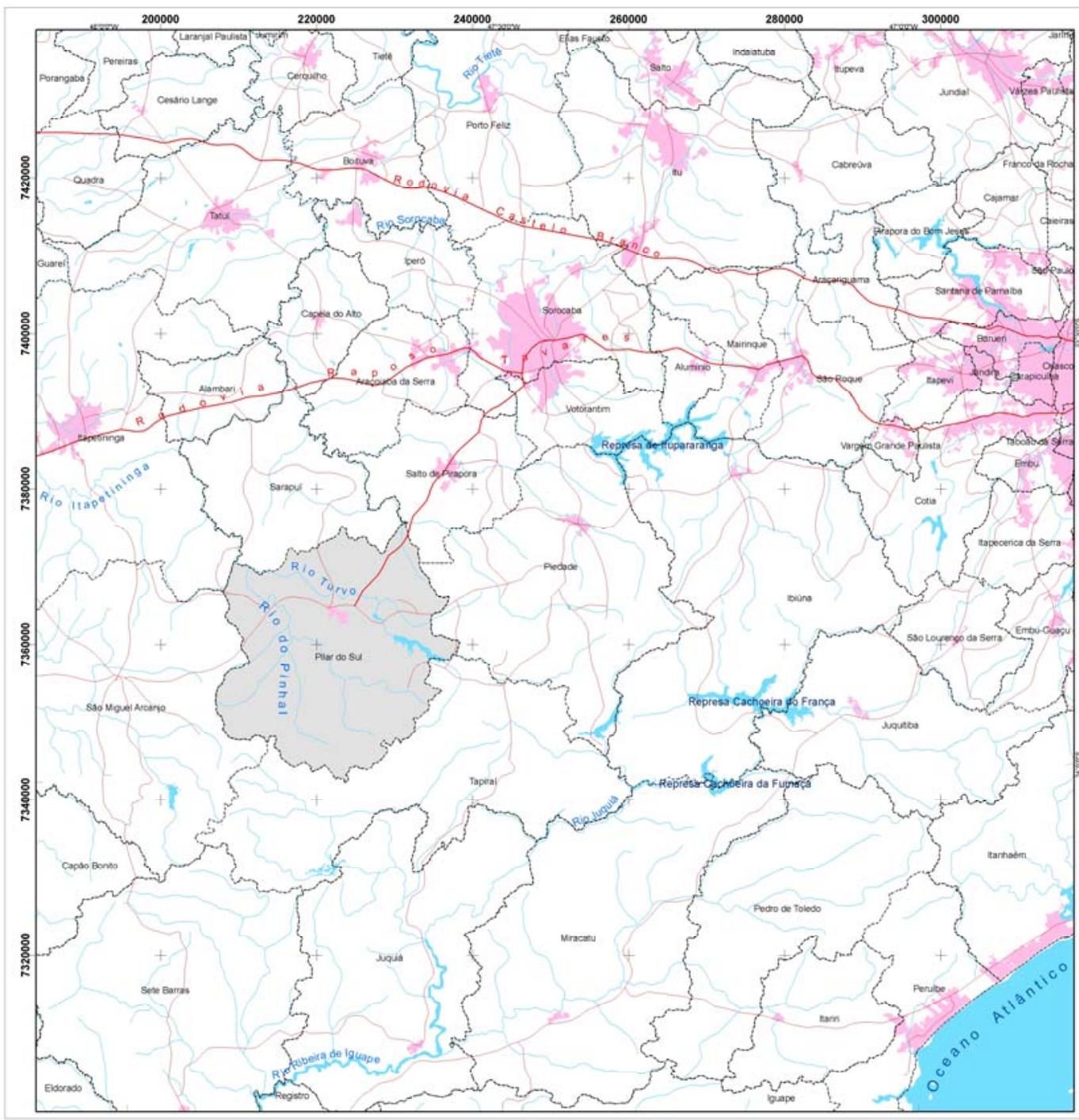

Figura 1

Mapa de Localização do Município de Pilar do Sul

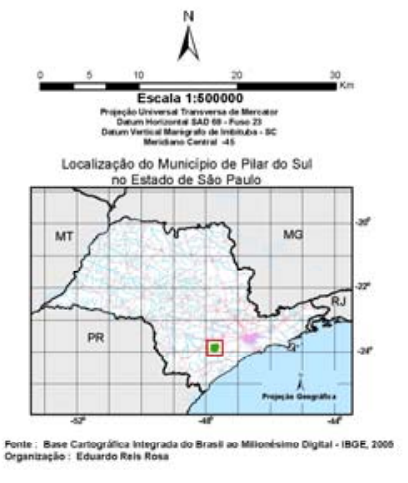


A síntese das diversas informações levantadas no projeto é representada pelo Mapa de Potencial de Degradação Ambiental e pelo Mapa de Classes de Capacidade de Uso da Terra adaptado da metodologia de LEPCSH. O produto final do estudo é o Mapa de Zoneamento Agroecológico, que visa dar apoio ao planejamento de práticas de conservação dos solos de acordo com a aptidão agrícola e as limitações ambientais no meio rural. O Zoneamento delimita unidades ambientais que auxiliam no ordenamento do meio físico, resultando numa exploração racional dos recursos ambientais em Pilar do Sul.

AB'SÁBER, em transcrição de uma conferência publicada na "Revista de História", em 1969, aponta a necessidade de melhores indicações agro-técnicas para a utilização econômica racional e sistemática dos solos depauperados por 150 anos de atividades predatórias. A retaguarda Atlântica do país, está "...à espera de planos de recuperação dos solos e de um conjunto de atividades produtivas mais adequadas, capazes de re-valorizar enormes espaços de pequeno rendimento econômico."

As classes de cada mapeamento temático são a base do sistema de classificação. As classes permitem diferenciar as formas de organização do espaço e são adquiridas em função da análise do ambiente. A reorganização de cada variável ou classe define mapas derivados de cada fator de análise. A combinação ponderada dos mapeamentos derivados gera mapas síntese, que, combinados, resultam no Mapa de Zoneamento Agroecológico. 


\section{Objetivos e Desafios}

A pesquisa tem como objetivo elaborar o Mapa de Zoneamento Agroecológico para o Município de Pilar do Sul, com a integração de dados utilizando-se recursos de geoprocessamento.

O Projeto de Pesquisa desenvolve metodologias e técnicas de levantamento de dados, abordados durante o processo de estudos acadêmicos realizados no Campus da Universidade de São Paulo e também no Campus da Universidade Federal de Lavras. Os fatores de análise teórico-metodológico, abordados no projeto, auxiliam na elaboração de planos diretores de municípios, nos planejamentos ambientais, na conservação dos recursos naturais, na recuperação de áreas degradadas e em estudos que envolvem a identificação, caracterização e o levantamento de dados relativos aos diversos elementos que compõem o meio ambiente.

Qualquer intervenção no ambiente pode resultar em alteração das condições naturais. A identificação de áreas agricultáveis viabiliza o direcionamento racional do desenvolvimento agrícola, prevenindo que o manejo agrícola não resulte em degradação das condições naturais. O estudo identifica as formas de se otimizar a utilização do solo, recomendando o uso mais adequado de acordo com as limitações e potencialidades de cada área.

O Código Florestal, as resoluções do CONAMA, as Legislações Federal e Estadual, estabelecem áreas destinadas à preservação e à conservação de recursos naturais, os quais devem ser respeitadas. Os impactos gerados pela exploração são conseqüências de usos ou ações incorretas, evitadas se melhor pensadas, melhor analisadas e melhor planejadas com bases em informações teóricas e práticas. Os projetos de estudos ambientais e regionais orientam o uso adequado da terra.

O desafio é que a pesquisa seja aplicada de forma a ajudar na preservação dos mananciais, conservando áreas que devem ser preservadas pelo simples fato de ainda existirem ou, ainda, pelo fato de serem consideradas instáveis ou 
potencialmente sujeitas à ocorrência de processos que degradam o ambiente. $O$ projeto de pesquisa recomenda práticas que, adotadas, minimizam impactos ambientais causados com a exploração do ambiente.

Com base nesse pensamento, os fatores e parâmetros que determinam as classes do Zoneamento Agroecológico são analisados e inter-relacionados no desenvolvimento dos diversos mapeamentos do Município. A Figura 2 - Integração dos Dados, apresenta a seqüência para se determinar o Mapa de Zoneamento Agroecológico para o Município de Pilar do Sul. 
Figura 2 - Integração dos Dados

\section{Levantamento}

de

Dados

Sistematização

dos

Dados em SIG

Análise Integrada

dos Temas

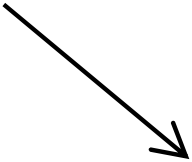

Zoneamento

Agroecológico 


\section{Procedimentos Metodológicos}

A Cartografia e o Geoprocessamento são trilhas a serem percorridas, orientadas pelo raciocínio metodológico de ANDRÉ LIBAULT, seguindo as etapas dos "Quatro Níveis da Pesquisa Geográfica" (LIBAULT - 1971).

O nível Compilatório abrange os trabalhos iniciais de campo para reconhecimento e caracterização da área de estudo, levantando informações gerais, bibliografias específicas, cartas temáticas, cartas topográficas, base cartográfica (digital e analógica), imagens de satélite, imagem de radar, fotografias aéreas; estudo e seleção de informações que caracterizam a área quanto à geologia, pedologia, hipsometria, clinografia, geomorfologia, climatologia, hidrologia, uso e cobertura da terra e sócio-economia. Nesta etapa, organizam-se as informações e os conhecimentos a serem integrados e interpretados nas etapas subseqüentes.

No segundo nível da pesquisa, o Correlatório, aplicam-se correlações técnicocientíficas às informações, apresentando uma síntese parcial da análise integrada dos temas. Os mapeamentos intermediários de Potencial de Degradação Ambiental e de Capacidade de Uso da Terra são gerados e analisados.

No nível Semântico, aborda-se uma interpretação geral e final da análise integrada dos conhecimentos, gerando-se o Mapa de Zoneamento Agroecológico.

O projeto de pesquisa propõe normas e recomendações de uso para as diferentes regiões do município com o objetivo de auxiliar o planejamento territorial, com foco na utilização racional da terra e na conservação dos recursos naturais. $A$ Prefeitura de Pilar do Sul desenvolve projetos que visam à melhoria da qualidade de vida da população e a aplicação das informações levantadas no presente estudo é a proposta do nível Normativo.

A exploração agrícola de forma indisciplinada e sem planejamento desequilibra o ambiente, gera impactos e provoca danos, às vezes, irreversíveis. O uso de técnicas de Geoprocessamento como suporte para a análise do meio ambiente foi 
fundamental no desenvolvimento do projeto, que se iniciou com a coleta de dados estatísticos e bibliográficos em entidades ligadas ao Município de Pilar do Sul (Prefeitura Municipal, Secretaria de Obras, Secretaria do Desenvolvimento e Meio Ambiente, Biblioteca Municipal e Casa da Agricultura), no Departamento de Águas e Energia Elétrica do Estado de São Paulo - DAEE, no Instituto Agronômico de Campinas - IAC, na Coordenadoria de Assistência Técnica Integral - CATI, no Instituto Geográfico Cartográfico - IGC, no Instituto Nacional de Pesquisas Espaciais - INPE, na Empresa Brasileira de Pesquisa Agropecuária - EMBRAPA, na Universidade de São Paulo - USP, na Universidade Federal de Lavras - UFLA e na Escola Superior de Agricultura "Luiz de Queiroz" - ESALQ / USP.

O levantamento bibliográfico e as informações que caracterizam a área de estudo possibilitaram a sistematização dos dados e a geração de mapeamentos temáticos de acordo com parâmetros que melhor se adaptaram à área de estudo. As informações sobre a realidade local foram fundamentais para se avaliarem os problemas de degradação ambiental existentes e para se determinarem práticas a serem adotadas na manutenção dos recursos naturais para as gerações futuras.

O geoprocessamento ofereceu o suporte tecnológico para o processamento dos dados espaciais, integrando conceitos de geodésia, cartografia digital, aerofotogrametria, sensoriamento remoto, modelagem digital de terrenos e sistemas de informações geográficas com o objetivo de produzir mapas associados a uma base de dados.

Os Sistemas de Informações Geográficas (SIG) permitem a entrada, o armazenamento, o tratamento e a análise de dados geo-referenciados. A produção de base topográfica e de mapeamentos temáticos em meio digital facilita o processo de análise geográfica, necessário para a geração do mapa de Zoneamento Agroecológico.

Os SIG's "são sistemas constituídos por uma série de programas e processos de análise, cuja característica principal é focalizar o relacionamento de determinado fenômeno da realidade com sua localização espacial" (Teixeira A.L.A., Moretti E., Christofoletti A. - 1992). 
Uma das principais funções do SIG é a integração, em única base de dados, de informações espaciais e alfanuméricas, provenientes de dados cartográficos, dados cadastrais, imagens de satélite, redes e modelos numéricos de terreno. Uma vez armazenadas as informações, o software oferece mecanismos e algoritmos de manipulação e análise, possibilitando a consulta, a recuperação, a geração de novas informações, a atualização, visualizações e a impressão do conteúdo da base de dados.

O requisito de armazenar a geometria dos objetos geográficos e seus atributos representa uma dualidade básica no SIG. Para cada objeto geográfico, o SIG armazena seus atributos e as várias representações associadas. Com estrutura de um Banco de Dados, o SIG relaciona estes dados com os diferentes objetos ou fenômenos representados em formas de mapas, podendo ser criados em diferentes projeções e escalas.

Para auxiliar na manipulação dos dados, os softwares Spring, ArcView, ArcGis, Arclnfo e Imagine 8, foram contemplados em situações específicas. Os SIG's possibilitam a elaboração de mapas que utilizam as convenções cartográficas como forma de comunicação e integram os diferentes mapeamentos temáticos.

As informações referentes aos aspectos físicos, bióticos e sócio-econômicos relacionam-se espacialmente, através de entidades mapeadas. O processamento das informações no sistema gera produtos, base para análises e tomada de decisões. O desenvolvimento de um banco de dados geográfico, que caracterize uma determinada área de estudo em SIG, possibilita não só acesso para consultas e pesquisas, mas também a atualização e complementação dos dados.

A entrada e a integração de dados possibilitam gerar diferentes tipos de informações no SIG. A representação dos dados e informações através de mapas deve seguir determinadas normas cartográficas. O conceito de Cartografia passou a considerar a possibilidade de elaboração de mapas e outros documentos cartográficos com o auxílio do computador, modificando para isso, a forma de registro e de armazenamento dos dados em diferentes tipos de mídias (Rosa, F. S. - 1996). Os princípios básicos da Cartografia, no entanto, permanecem válidos e 
persistindo a sua divisão em dois grandes grupos: a Sistemática e a Temática. A Cartografia Sistemática é a "ciência responsável pela representação genérica da superfície tridimensional da Terra no plano, através de convenções e em escalas padrão". A Cartografia Temática aborda a cartografia como "linguagem, pela qual os fenômenos e objetos da Geografia, as relações entre dados, forças e elementos do espaço geográfico são representados." (Rosa, F. S. - 1989).

A metodologia adotada para o desenvolvimento da pesquisa baseia-se na integração de dados obtidos de mapas pré-existentes, tanto topográficos como temáticos, na interpretação de fotografias aéreas, de imagens de satélite, de imagem de radar e informações levantadas e checadas com os trabalhos de campo. A utilização do SIG é fundamental no processo de compilação de dados, generalização cartográfica, mudança e adaptação de escalas e sistemas de projeção, integração e análise dos dados, e na definição de legendas e simbologias para a apresentação dos mapas.

A tecnologia do geoprocessamento fornece apoio analítico à pesquisa. As operações nos sistemas de informações seguem metodologias e técnicas de trabalho especializadas e especificas a cada software. As análises espaciais e as interações entre os diferentes níveis temáticos auxiliam os estudos territoriais com o objetivo de auxiliar a tomada de decisão sobre questões que envolvem o espaço geográfico, seja no âmbito urbano como no rural.

Na sistematização da base topográfica digital, foram utilizadas informações dos arquivos digitais do DAEE correspondentes às folhas topográficas $1: 50$ 000, do IBGE:

- Folha de Pilar do Sul - SF-23-Y-C - IV-4

- Folha de São Miguel Arcanjo - SF - 23 - Y - C - IV - 3

- Folha de Salto de Pirapora - SF - 23-Y - C - IV - 2

- Folha de Sarapuí - SF-23-Y-C - IV - 1 
De posse desses arquivos, efetuou-se a conversão e o processamento dos dados em formato adequado para uso em SIG. Na preparação do mapa topográfico digital em ambiente SIG, foi necessária a junção de Folhas Topográficas para construção de uma base topográfica contínua e a atribuição de cotas nas curvas de nível. O uso de fotografias aéreas permitiu a atualização da base topográfica dos elementos de sistema viário, hidrografia e edificações/localidades (uso e cobertura da terra).

A configuração da rede de transportes no Estado de São Paulo está associada ao processo de ocupação do território e historicamente ligada às características da topografia e da rede hidrográfica (Marques M. - 1975). As fotografias aéreas foram eficientes no processo de atualização do sistema viário, no qual se constatou uma expansão da malha urbana e um adensamento das estradas rurais.

Com a base topográfica em SIG, utilizaram-se os dados da base altimétrica e da hidrografia, na geração do modelo digital de terreno, o que permitiu a elaboração dos Mapas Hipsométrico e Clinográfico, de acordo com parâmetros que melhor representam a variação do relevo no Município.

O Mapa Hipsométrico representa a variação altimétrica no Município em 8 classes:

$<600$ metros

600- 650 metros

650-700 metros

700- 750 metros

750 - 800 metros

800-900 metros

900-1000 metros

$>1000$ metros 
As classes de declividades representativas do relevo do Município foram definidas com base nos estudos de De Biasi (1970, 1992), Chiarini \& Donzeli (1973), Lepsch et allii (1983) e Bertoni \& Lombardi Neto (1990), optou-se por representar a variação das declividades para caracterizar o relevo com as seguintes classes: <2\% em Planície Aluvial, <2\% em topos aplainados, 2\% a 12\%, 12\% a 20\%, 20\% a 47\% e > 47\%. No entanto, para atender à finalidade de auxiliar as correlações e detalhamento dos mapeamentos geomorfológico, potencial de degradação do ambiente e de capacidade de uso da terra adotou-se uma classificação mais detalhada:

<2\% em Planície Aluvial - Áreas de ocorrência de solos hidromórficos na Depressão Periférica. Parâmetro utilizado para detalhamento das informações pedológicas no mapa geomorfologico.

$<8 \%$ - Parâmetro utilizado para detalhamento e associação das classes pedológicas no mapa geomorfológico, determinando áreas com a predominância de Latossolos no Planalto Atlântico.

>12 \% - Parâmetro utilizado no Mapa de Classes de Capacidade de Uso da Terra para diferenciar áreas de Classe IV de áreas de Classe III na Depressão Periférica do Município.

>20 \% - Parâmetro utilizado para detalhamento e associação das classes pedológicas definidas no mapa geomorfológico, determinando áreas com a predominância de Argissolos na Depressão Periférica.

>30 \% - Parâmetro utilizado na determinação de áreas onde a incidência de processos erosivos passa a ser mais severa e determinante no estabelecimento de alto potencial de degradação ambiental.

> 47 \% - Parâmetro utilizado na determinação de áreas onde é favorável a ocorrência de Cambissolos e Neossolos Litólicos no Planalto Atlântico. 
As informações pedológicas foram compiladas de mapas pré-existentes e detalhadas com o auxilio das fotografias aéreas e da integração das informações dos Mapas Hipsométrico e Clinográfico, resultando no Mapa Geomorfológico.

O Mapa Pedológico do Estado de São Paulo (Embrapa / IAC - 1999), apresentado na Figura 3 apresenta a seguinte subdivisão do Município:

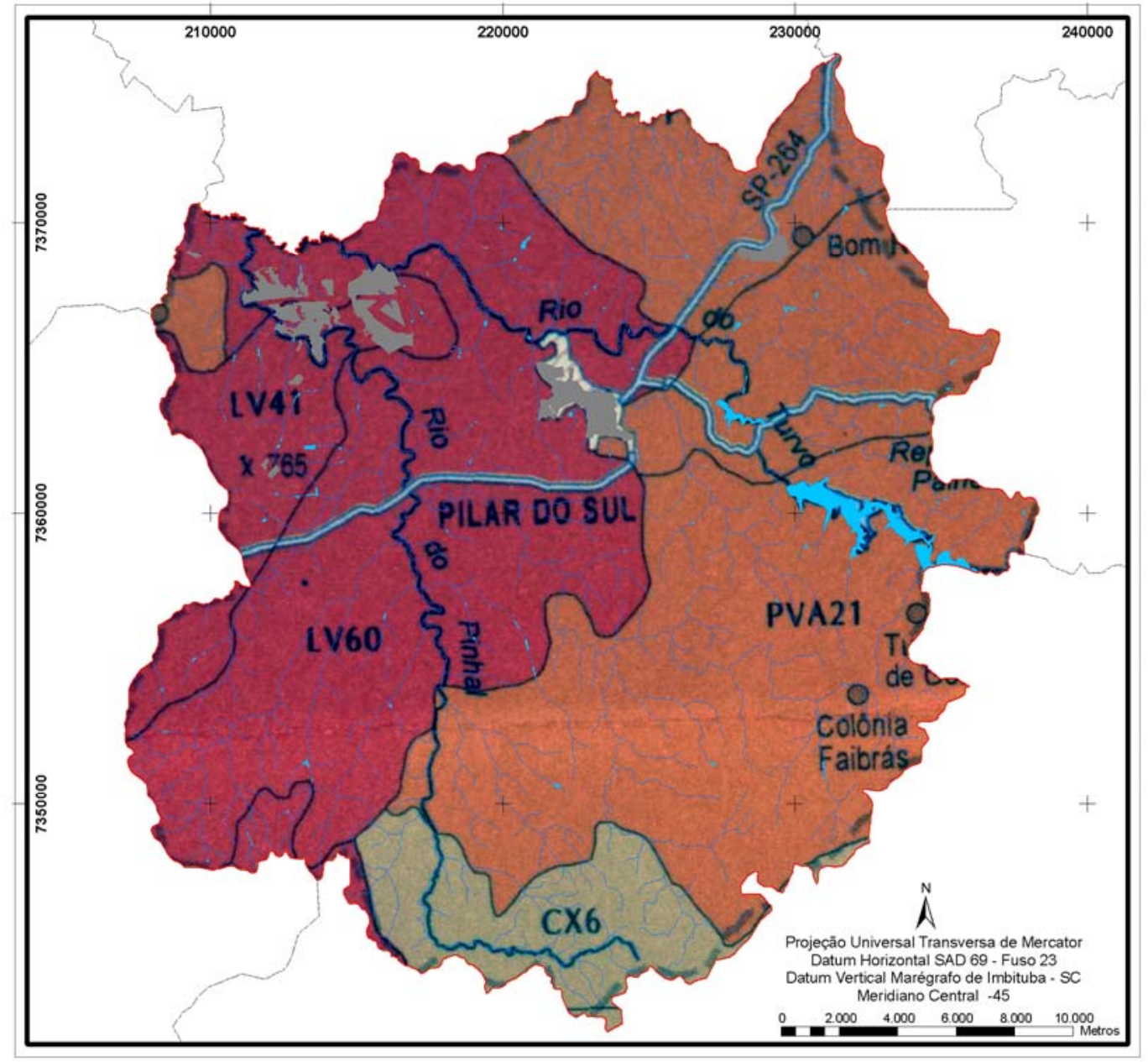

Figura 3 - Mapa Pedológico do Estado de São Paulo (Embrapa / IAC - 1999)

- os solos da classe LV60 e LV41 ( ) são Latossolos Vermelho, Vermelho Escuro e Vermelho - Amarelo, todos distróficos (saturação por bases inferior a $50 \%$ ) com horizonte A moderado de textura argilosa (mais que $35 \%$ de argila) e em áreas de relevo suave ondulado $(3-8 \%)$ a ondulado $(8-20 \%)$. 
- as classes PVA21 e PVA55 ( ) representam Argissolos Vermelho Amarelo, distróficos, com horizonte A moderado de textura argilosa em áreas de relevo forte ondulado (20 a 45\%) e ondulado. A classe PVA55 apresenta textura média argilosa, associados à Latossolos Vermelho - Amarelo e corresponde a área à nordeste do município.

- a classe CX6 ( ) representa os Cambissolos Háplicos de horizonte A moderado com argila de baixa atividade, textura argilosa e argilosa com cascalhos, e localizados em relevo montanhoso (45\% a $75 \%)$.

O uso de imagens de satélite, imagem de radar e fotografias aéreas auxilia na caracterização e detalhamento dos levantamentos de classes de solos, permitindo análises, interpretações e correlações a respeito de certas propriedades dos solos, do relevo, da drenagem, da cobertura vegetal e de padrões de uso da terra (Novo E. M.L.M. - 1988).

O Mapeamento Geomorfológico do Estado de São Paulo (Ross J. L. S., Moroz I. C. - 1997) (Figura 4) na escala de 1:250000, foi o ponto de partida na adaptação das diferenças geomorfológicas no Município e na integração das informações que caracterizam propriedades específicas de pedologia e morfologia de vertentes. 


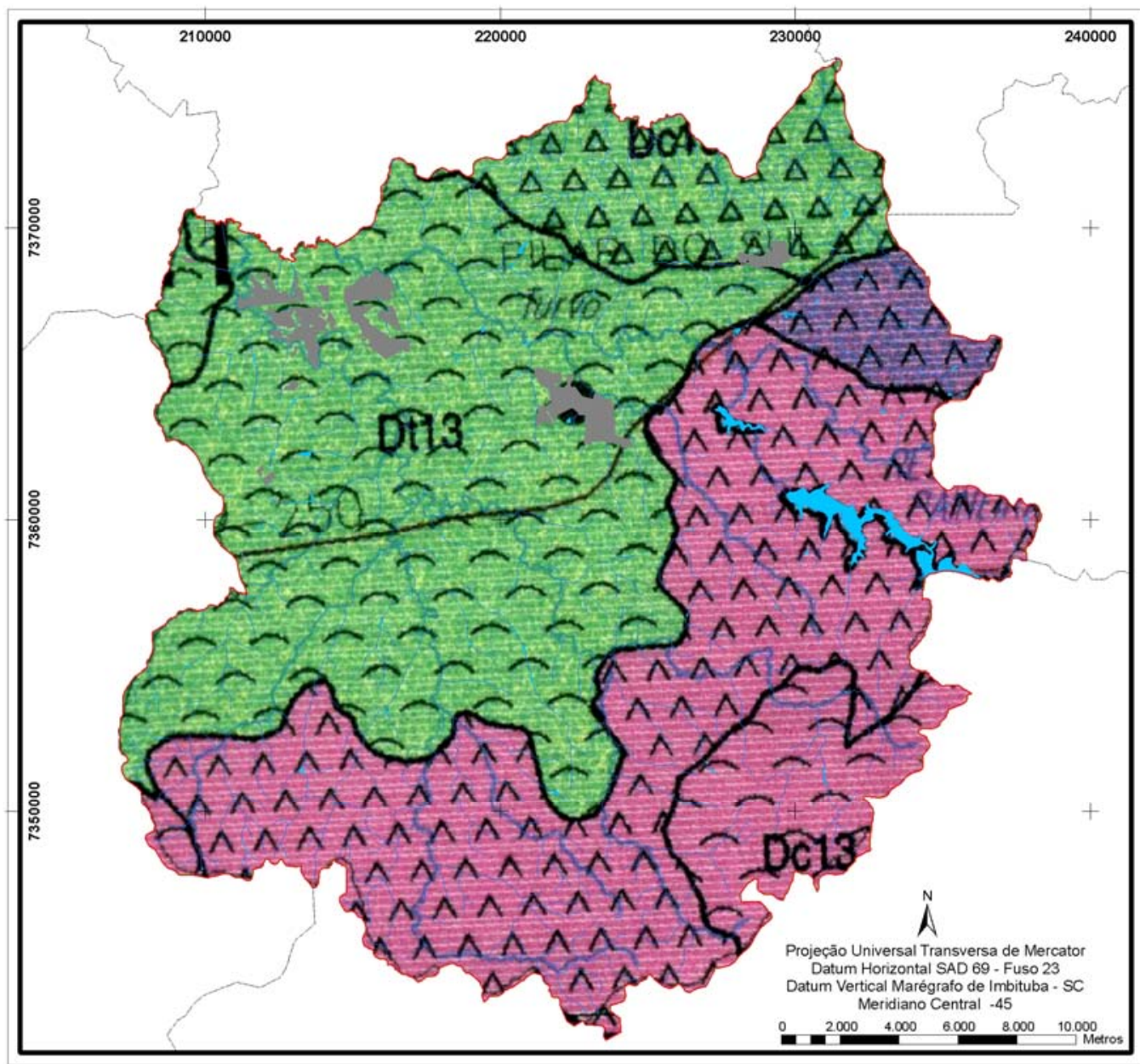

Figura 4 - Mapeamento Geomorfológico do Estado de São Paulo (Ross J. L. S., Moroz I. C. - 1997)

No Mapa, o município de Pilar do Sul está localizado na transição da unidade morfológica denominada Planalto de Ibiúna / São Roque ( $\hat{\wedge} \mathcal{L}$. ) e da unidade morfológica denominada Depressão Periférica Paulista / Depressão Periférica Paranapanema ( função das formas de relevo, caracterizando os tipos de modelado, índice de dissecação, altimetrias, declividades e solos dominantes em cada classe.

A Geomorfologia é instrumento de análise e síntese do meio físico e suporte para os estudos ambientais, que devem ser integrados ao contexto sócioeconômico regional. 
Para essa caracterização, foi elaborado o Mapa de Uso e Cobertura da Terra, por meio da interpretação de fotografias aéreas do recobrimento aerofotogramétrico na escala 1: 30000 , de 2000, auxiliado por imagem de satélite LANDSAT do ano de 2000, com resolução espacial de 15 metros e com imagem LANDSAT de 1995.

A Carta de Utilização da Terra do Estado de São Paulo (Figura 5), interpretada com base nas fotografias aéreas de 1978 na escala 1:35000, destaca, no Município de Pilar do Sul, a atividade de silvicultura em vermelho, áreas de culturas anuais em bege, áreas de fruticultura em roxo, áreas de pastagem em amarelo e, ao sul, a grande área de Mata Atlantica.

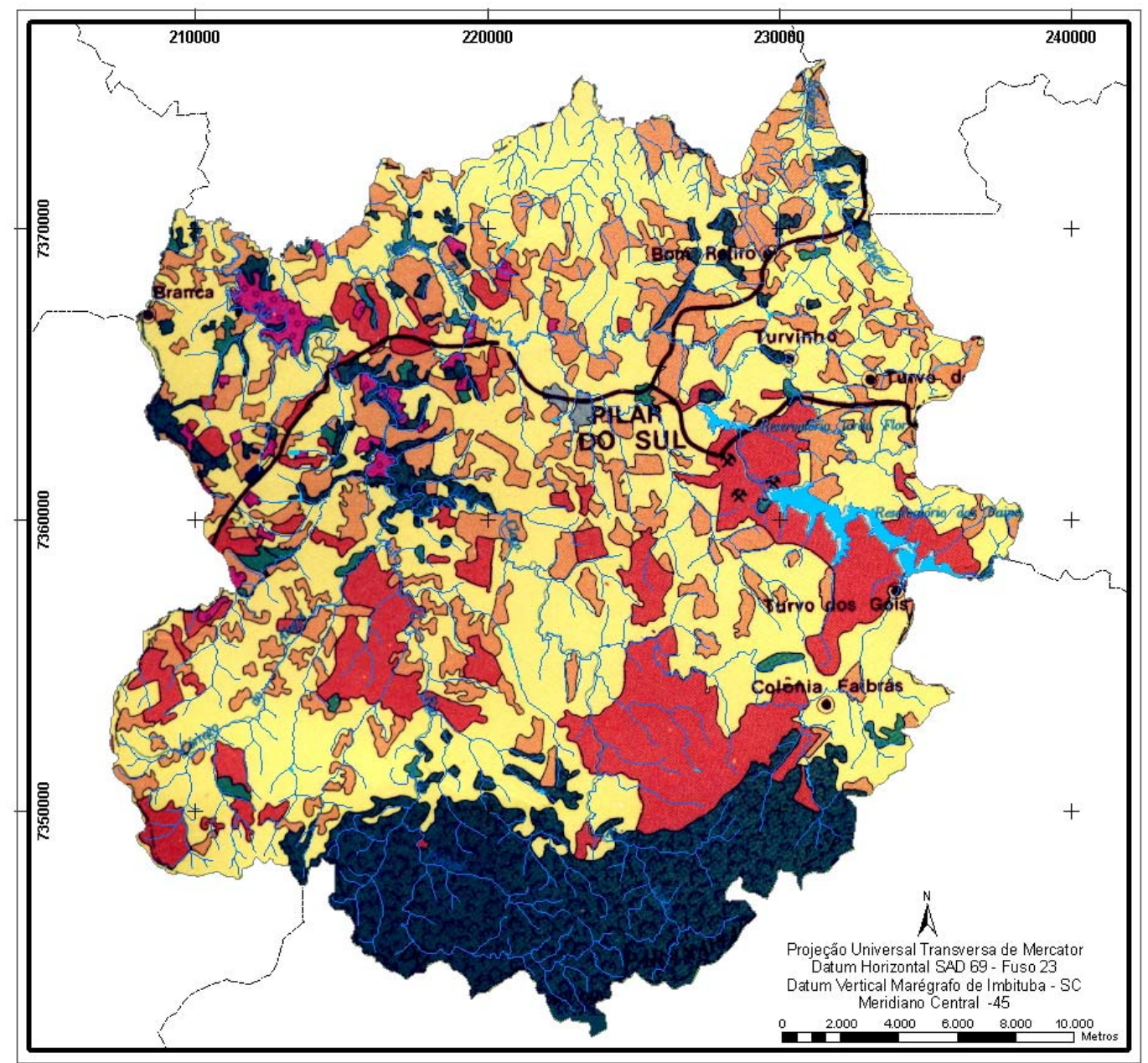

Figura 5 - Carta de Utilização da Terra do Estado de São Paulo - 1981 
Este mapa serve de base para análise da evolução do uso e ocupação da terra no Município, avaliando o desenvolvimento da atividade agrícola.

O mapeamento de Uso e Cobertura da Terra realizado no projeto de pesquisa foi complementado com os reconhecimentos de campo e entrevistas com proprietários de terras e trabalhadores rurais, a fim de se identificarem as práticas de manejo empregadas no Município. A definição das classes de uso foi adaptada ao contexto da área a partir da proposta de Keller, 1968. As figuras 6 e 7 exemplificam o mapeamento de uso e cobertura da terra, onde, em roxo, são áreas de silvicultura; em laranja, áreas de agricultura anual; em marrom, áreas de agricultura perene; em vermelho, áreas de solo exposto; em verde claro, áreas de pastagem; e, em verde, áreas de Mata Atlântica.

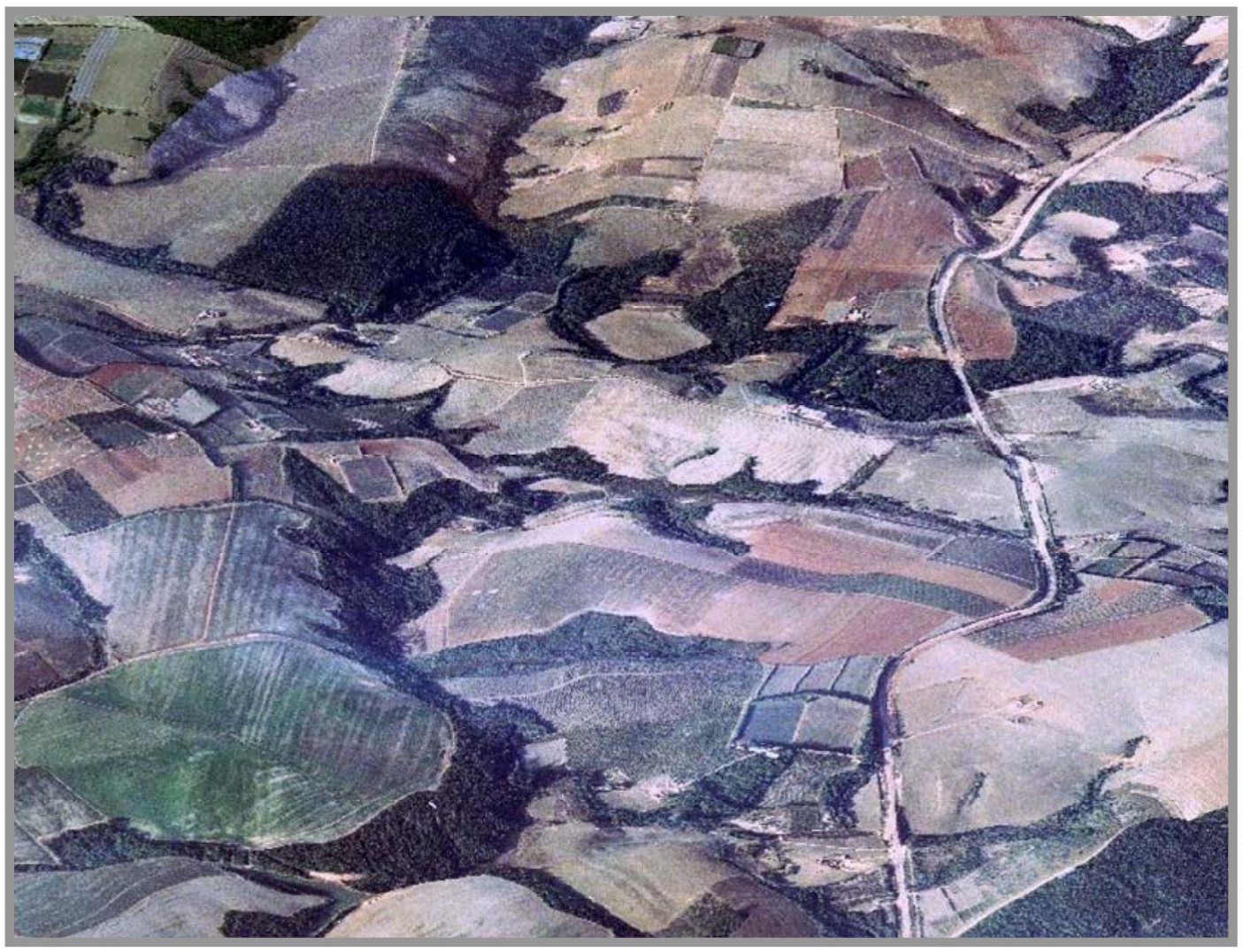

Figura 6 : Visualização tridimensional de fotografia aérea 


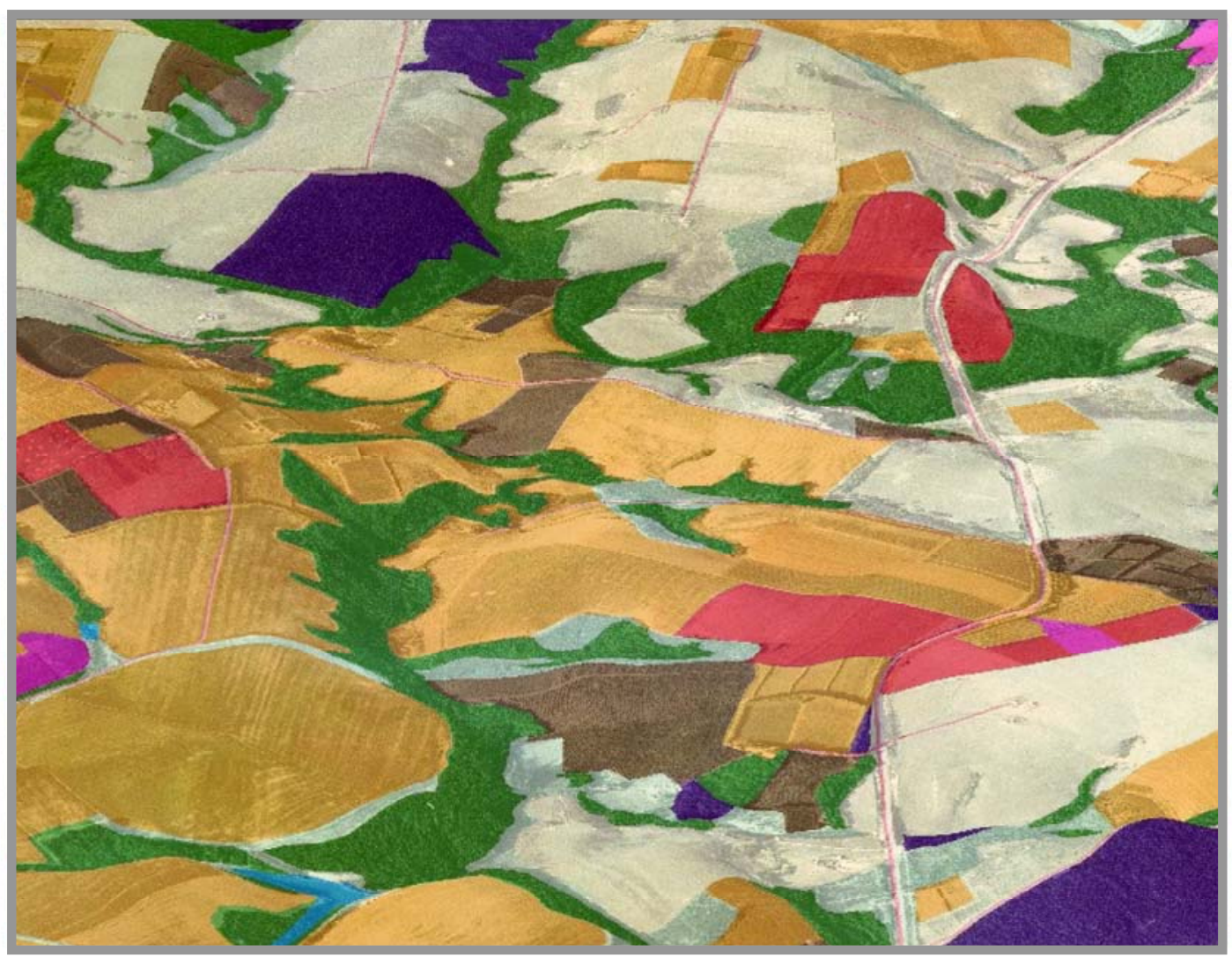

Figura 7: Visualização tridimensional da classificação do Uso da Terra.

A questão ambiental é, antes de tudo, social. São necessárias reformas que orientem os sistemas de produção agrícola de forma racional e objetiva. A falta de conhecimento de aspectos do relevo, assim como sua estrutura, litologia e solos resulta na degradação do ambiente e na sub-utilização dos recursos naturais. Diante desta constatação, partiu-se para uma correlação entre os aspectos físiconaturais e os aspectos antrópicos, visando definir o nível de degradação das diferentes áreas do Município.

A cartografação dos ambientes naturais e antropizados possibilitou um refinamento do diagnóstico, oferecendo melhores elementos para o planejamento sócio-econômico e ambiental. A possibilidade de espacialização dos diferentes geofatores e a representação deles através de mapas integrados, permitiu a análise do espaço geográfico em sua essência, definindo potenciais de uso diferenciados de acordo com as possibilidades identificadas. Áreas potencialmente mais 
favoráveis ao uso agrícola e áreas mais suscetíveis à erosão são definidas pela análise de diferentes fatores que merecem algumas considerações.

Os processos erosivos que existentes em ambientes de cobertura vegetal natural e sem influências antrópicas é denominada de erosão natural ou geológica, e se manifesta de forma muito lenta, sendo perceptível somente com o decorrer de longos períodos de atividade (Bertoni \& Lombardi Neto - 1990; Marque - 1995).

O processo erosivo tem início com o impacto das chuvas no solo desprotegido, gerando o escoamento superficial das águas que transporta sedimentos encosta abaixo. A erosão pode ser do tipo laminar, que resulta na remoção progressiva dos horizontes superficiais do solo; em sulcos, quando aparecem incisões na superfície do terreno podendo evoluir por aprofundamento em ravinas; e voçoroca, quando os fluxos de águas subsuperficiais, incluindo o lençol freático, também influenciam na remoção de partículas da superfície e do interior do solo (Bertoni \& Lombardi Neto 1993).

A relação entre a quantidade e intensidade de chuvas, a presença e tipo de cobertura vegetal, a topografia e o tipo de solo é que vão determinar a evolução dos processos erosivos, assim como as perdas de solo. A ocorrência da erosão em áreas de pastagem está relacionada ao caminhamento do gado e à falta ou dimensionamento incorreto dos terraços, fatores que intensificam e concentram a ação das águas.

A primeira equação conhecida para se estimar a perda de solos foi publicada por Zingg, R. W. (1940), que relacionava a perda do solo com a declividade e o comprimento de rampa. Posteriormente, adicionou a influência da cobertura do solo, de práticas conservacionistas e do fator chuva. Com a proposta de Meyer \& Wischmeier -1969 (Bigarella, J. J. - 1985), a equação passou a ser denominada EUPS (Equação Universal de Perdas de Solo) ou USLE (Universal Soil Loss Equation) e vem sendo utilizada e adaptada em diferentes ambientes para identificar o risco de erosão.

A EUPS estima as perdas anuais de solo ocasionadas por erosão sendo representada pela equação: 

$A=R K L S C P$ onde:
$A=$ perda de solo
$\mathbf{R}=$ fator erosividade da chuva
$\mathbf{K}=$ fator erodibilidade do solo
$\mathbf{L}=$ fator comprimento de rampa
$\mathbf{S}=$ fator grau de declive
$\mathbf{C}=$ fator uso e manejo
$\mathbf{P}=$ fator prática conservacionista

O que se propõe é uma adaptação da Equação Universal de Perdas do Solo, para as condições do Município, adequando-a ao uso da tecnologia de geoprocessamento, com a finalidade de estabelecer o Potencial de Degradação

\section{Ambiental.}

Na identificação do Potencial de Degradação Ambiental, os fatores considerados são aqueles que representam o meio físico e os fatores de uso, o manejo e a presença ou não de práticas de conservação do solo.

O fator erosividade da chuva reflete na perda de solo, de forma diretamente proporcional a sua intensidade e energia cinética (Bertoni \& Lombardi Neto - 1990). Os problemas de perda de solo se agravam em solos sem cobertura vegetal e em épocas do ano onde é maior a intensidade de chuvas. Dessa forma, é necessário o conhecimento das condições climáticas, para se preverem as melhores épocas para introdução de práticas conservacionistas e para qualquer tipo de manejo que envolva a alteração na cobertura vegetal dos solos.

O Mapa Geomorfologico é a base para análise e avaliação dos fatores de comprimento de rampa e erodibilidade do solo. A complementação da geomorfologia com informações pedológicas integradas ao estudo de caracterização das vertentes, utilizando informações do Mapa Hipsométrico e Mapa 
Clinográfico, permite identificar áreas potencialmente sujeitas à ocorrência de diferentes intensidades de processos erosivos.

A determinação de faces de Orientação de Vertentes orientou o processo de análise das vertentes, estabelecendo referencial para as medições dos comprimentos de rampa e das respectivas variações altimétricas.

A Orientação de Vertentes identifica vertentes que recebem maior luminosidade (incidência de raios solares) e vertentes sujeitas à incidência de ventos frios, mais sujeitas às condições de maior umidade e temperaturas mais baixas. Tais fatores podem influenciar na escolha da cultura a ser implantada e do local onde a cultura se adapte melhor. Simielli (1981) analisou a "Variação Espacial de Capacidade de Uso da Terra" no Município de Jundiaí, efetuando a análise de variáveis topoclimáticas, geopedológicas e geoecológicas visando à elaboração da Carta de Capacidade de Uso da Terra, correlacionando-a, a seguir, com a Carta de Orientação de Vertentes, concluindo ser esta variável de grande importância, principalmente em áreas de relevo mais acidentado. Em Pilar do Sul, no entanto, nas regiões de relevo mais acidentado, a silvicultura não é afetada por essas variações e, nas áreas de relevo menos acidentado, as práticas de cultivo protegido, a utilização de sombrite e plasticultura eliminam a interferência negativa das possíveis variações microclimáticas.

Dentre os fatores topográficos, a declividade da área é, possivelmente, o mais importante no condicionamento da gênese e evolução do processo erosivo. $\mathrm{Na}$ adaptação da Equação Universal de Perdas de Solo, o fator grau de declive é representado pelo Mapa Clinográfico, onde as maiores declividades representam um maior potencial à ocorrência de processos erosivos.

O fator uso, manejo e a presença de práticas conservacionistas é representado e identificado no Mapa de Uso e Cobertura da Terra.

O Mapa de Potencial de Degradação Ambiental, representa a adaptação dos fatores da Equação Universal de perdas do solo, dividindo o município em 5 classes, sendo que a classe 1 de potencial "nulo" de degradação do ambiente, é definida para ambientes relativamente estáveis, como áreas de Mata Atlântica 
primária ou em estágio avançado de regeneração e áreas de planícies aluviais vegetadas. Tais áreas sofrem pressão do próprio homem, no entanto a legislação impõe regras que, se obedecidas, contribuem para a manutenção desses ambientes. Os processos erosivos encontrados nesses ambientes não são degradantes. As classes 2, 3, 4 e 5 são determinadas em função da hierarquização dos diferentes aspectos do meio físico e sócio-econômico. A definição da classe 5 , de "muito alto" potencial de degradação do ambiente é estabelecido para áreas de vertentes muito íngremes e áreas que se encontram desprotegidas de vegetação ou, ainda, onde se identifica a ocorrência de processos erosivos, identificadas no mapeamento pelas classes de solo exposto e de áreas com erosão em ravinas.

Várias pesquisas e estudos têm sido realizados no País nos últimos 40 anos, aplicando as metodologias que levam à elaboração do Mapa de Classes de Capacidade de Uso da Terra. Apesar das diferenças de fatores levados em consideração, todos os trabalhos realizam o cruzamento dos dados relativos aos fatores julgados mais importantes para evidenciar o potencial e as restrições de uso da Terra.

Originalmente desenvolvido nos Estados Unidos da América por Klingebiel \& Montgomery (1961), o sistema de Capacidade de Uso das Terras vem sendo aplicado por vários autores em diferentes regiões do País, com sucessivas adaptações.

A IV Aproximação do Manual para Levantamento Utilitário do Meio Físico e Classificação das Terras no Sistema de Capacidade de Uso (Lepsch - 1983) preconiza a classificação da capacidade de uso das terras, através da interpretação de levantamentos das características diagnósticas que condicionam as potencialidades de uso das terras, bem como elementos adicionais necessários ao planejamento do uso da terra.

O sistema visa identificar as limitações permanentes e possibilidades de uso das terras, através da sistematização das informações de uma determinada área para definir a máxima capacidade de uso, sem que esta corra o risco de degradação do solo, especialmente do que diz respeito à erosão acelerada (Lepsch - 1991). 
Audi (1970) abordou o tema apresentando aspectos metodológicos para a Classificação de Solos em "Classes de Capacidade de Uso", com emprego de fotografias aéreas verticais, destacando a "importância desse sistema de agrupamento de solos nos trabalhos de planejamento agrícola, bem como o valor das fotografias aéreas na execução desses trabalhos".

Chiarini \& Donzeli (1973) realizaram o "Levantamento, por Fotointerpretação, das Classes de Capacidade de Uso das Terras do Estado de São Paulo", aplicando metodologia baseada no Manual Brasileiro para Levantamento da Capacidade de Uso da Terra com algumas modificações, apoiando-se nas características do solo, grau de erosão e classes de declividade. Nesse levantamento, o Município de Pilar do Sul (Figura 8) não apresenta terras próprias para utilização contínua com culturas anuais, em decorrência dos tipos de solos e do relevo com predominância de altas declividades. 


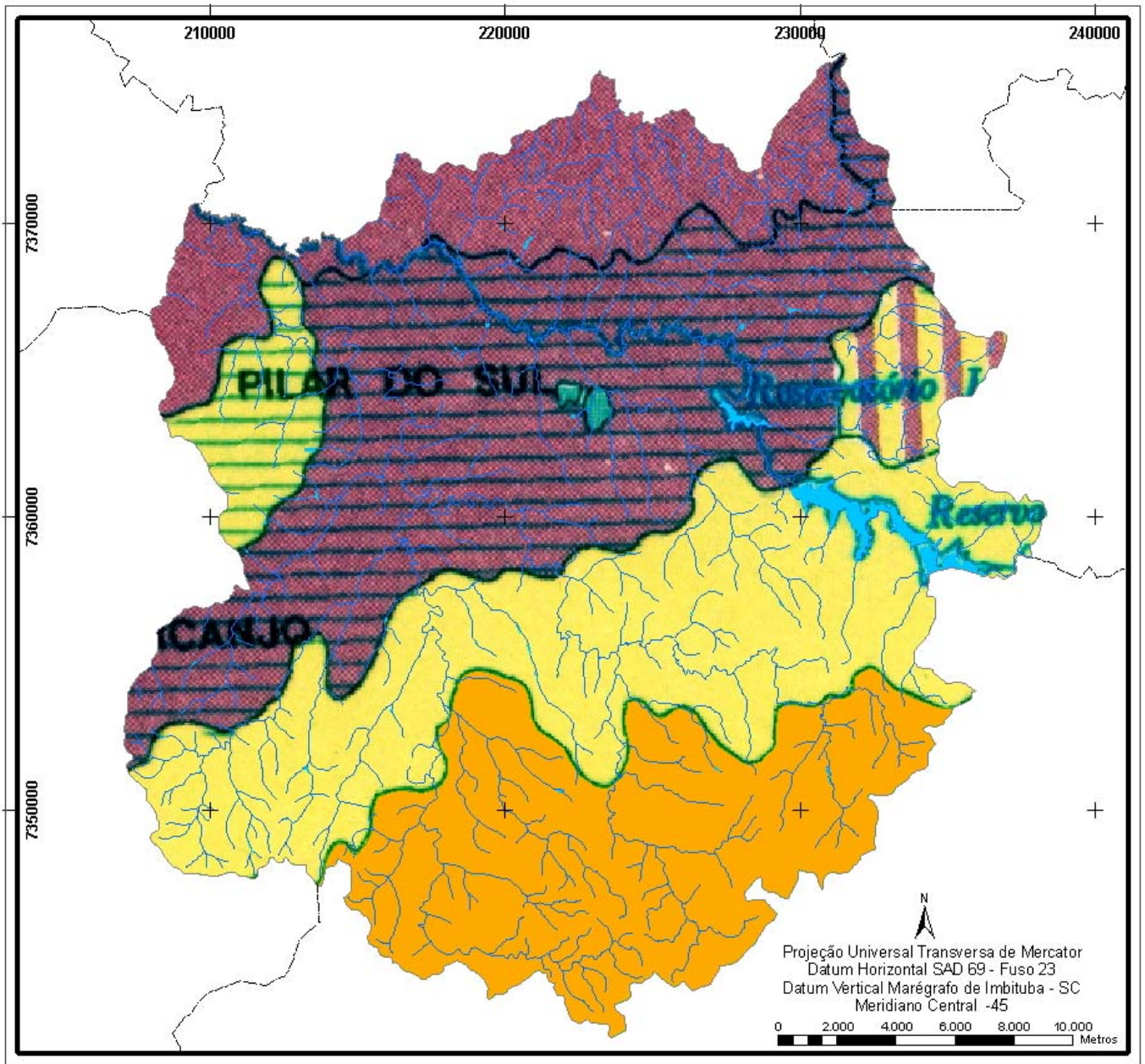

Figura 8 - Mapa de Classes de Capacidade de Uso da Terra (Org. CHIARINI J.V. \& DONZELI P.L.)

Classe IV - terras com declividades acentuadas (de 12 a 20\%) que não devem ser utilizadas de forma contínua com culturas anuais, sendo recomendadas para pastagens com eventual rotação com culturas anuais. São indicadas para culturas permanentes que proporcionam proteção ao solo, requerendo intensivas práticas de conservação - abrange as terras ao norte e noroeste do Município, correspondentes à Depressão Periférica. A subclasse IVf ( $)$ apresenta problemas de fertilidade e declividades de até $12 \%$, mais apropriadas à pastagem, prestando-se também à silvicultura. Sua utilização com culturas anuais e perenes requer técnicas adequadas. 
Classe $\mathbf{V I}$ - terras com altas declividades (20 a 40\%), que não se prestam a culturas anuais, sendo indicadas para pecuária e silvicultura, com práticas moderadas de conservação do solo - abrange as terras da região centro sul do Município, correspondente à área de transição da Depressão Periférica para o Planalto Atlântico. A subclasse VIf ( fertilidade com declividades de até $12 \%$, indicadas para silvicultura e pastagem;

Classe VII - terras com relevo muito acidentado com declividades predominantes superiores a $40 \%$, aptas somente a pastagens e silvicultura com limitações, sujeitas à erosão severa - abrange as áreas do extremo sul do Município, correspondendo à Serra de Paranapiacaba.

A Secretaria Nacional de Planejamento Agrícola - Suplam, pertencente ao Ministério de Agricultura, publicou, em 1979, o Mapa de Aptidão das Terras do Estado de São Paulo - Escala 1:1.000.000 - classificando as terras em 6 categorias adaptadas aos níveis de manejo A (baixo nível tecnológico), B (médio nível tecnológico) e $C$ (alto nível tecnológico). As terras da porção norte do Município foram classificadas como boas e regulares para níveis de manejo A, B ou C. Toda a região sul, correspondente às áreas do Planalto Atlântico, foi considerada do Grupo 6 - sem aptidão agrícola, a não ser em casos especiais, indicadas para preservação da flora e fauna ou para recreação.

Werlang (1997) elaborou a Carta de Capacidade de Uso da Terra na Bacia Hidrográfica do Rio Arareau - Rondonópolis - MT, demonstrando a possibilidade de diagnosticar as condições de uso da terra e elaborar os mapeamentos temáticos relativos ao meio físico, que subsidiaram a construção da carta final, a partir de técnicas cartográficas, que se constituem "num instrumento de grande valia para esse tipo de análise e registro de informações".

Brito (2001) elaborou um Mapa de Capacidade de Uso das Terras da Bacia do Ribeirão Bom Jardim, localizado no Triângulo Mineiro, visando identificar a 
adequação das potencialidades do uso da terra, utilizando-se das técnicas de geoprocessamento para a elaboração dos mapeamentos temáticos que caracterizam a área de estudo, bem como para o cruzamento dos dados e elaboração do mapa síntese, demonstrando a eficiência do software SPRING no desempenho das funções de manipulação, análise e geração das cartas.

As análises e correlações dos dados espaciais em ambiente de SIG permitem reclassificar cada mapa, combinando seus valores de acordo com parâmetros préestabelecidos, gerando classes e mapas derivados. As classes e mapas derivados foram ponderados segundo a análise individual dos fatores que levaram ao objetivo final do projeto de pesquisa, que é o Mapa de Zoneamento Agroecológico.

O Zoneamento para Pilar do Sul integra informações em uma base geográfica do município que auxilia na otimização do uso do espaço, levando em consideração as potencialidades e vulnerabilidades físicas e as regulamentações políticas de uso do território.

Adaptado da metodologia proposta por Becker - 1997, para execução do Zoneamento Ecológico-Econômico, o Zoneamento Agroecológico aqui proposto estabelece, para o município:

- áreas de preservação permanente;

- áreas urbanizadas;

- áreas aptas à atividade agropecuárias sem restrições de uso;

- áreas aptas à atividade agropecuária com restrições a culturas anuais;

- áreas cultiváveis apenas em casos especiais de algumas culturas permanentes e adaptadas, sendo próprias para pastagem e silvicultura;

- áreas a serem recuperadas.

A Figura 9 apresenta o fluxograma da Metodologia de Trabalho. 
Figura 9 - Metodologia de Trabalho

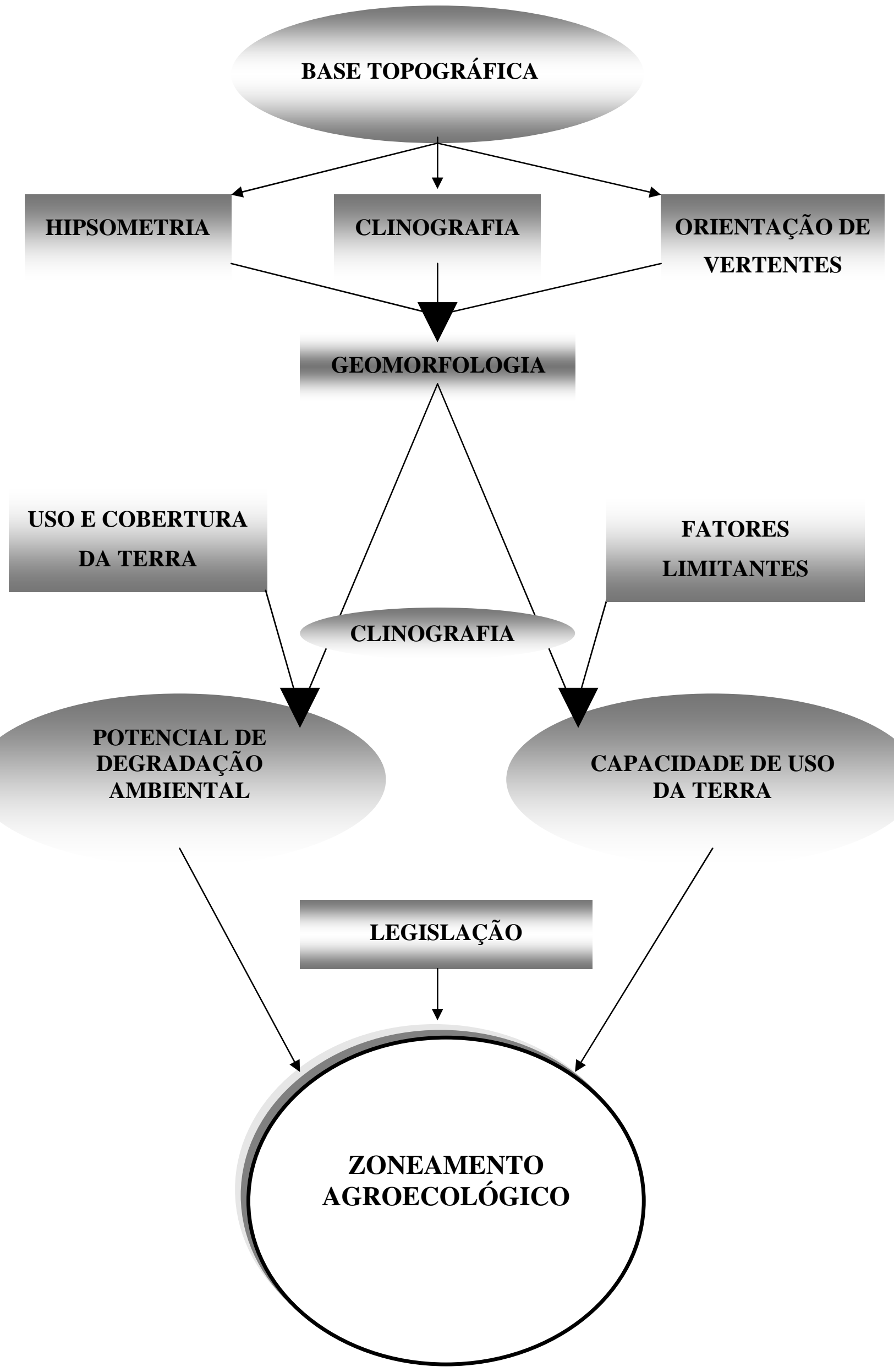




\section{Caracterização da Área de Estudo}

Pilar do Sul possui uma área de $683,395 \mathrm{Km}^{2}$, situada entre as coordenadas geográficas de $23^{\circ} 42^{\prime} 36^{\prime \prime}$ e $24^{\circ} 06^{\prime} 00^{\prime \prime}$ de latitude Sul e $47^{\circ} 34^{\prime} 12^{\prime \prime}$ e $47^{\circ} 52^{\prime} 12^{\prime \prime}$ de longitude Oeste de Greenwich. Localiza-se na região de Sorocaba, da qual dista 43 km em direção ao Sul, tendo como limites os municípios de Sarapuí, Salto de Pirapora, Piedade, Tapiraí, São Miguel Arcanjo e Itapetininga (Secretaria de Economia e Planejamento, Coordenadoria de Ação Regional - SP, 1978).

A história de Pilar do Sul está vinculada ao "ciclo do muar" ocorrido no Século XIX, anterior à construção da Estrada de Ferro Sorocabana (1875). Destinados a servir como meio de transporte para a região das Minas Gerais e, posteriormente, para as fazendas de café, os muares eram trazidos das regiões de campos do Sul do País, passando por Sorocaba, onde se estabelecia um grande entreposto de comércio, que atraía não só os interessados nos muares, como nas inúmeras outras atividades que faziam da cidade um centro de negócios com grande movimentação por ocasião da realização das "feiras de burros". "Sorocaba estava estreitamente ligada às atividades do comércio do muar determinado pela necessidade de meio de transporte animal para o Brasil e favorecido pela posição de Sorocaba entre duas regiões geo-econômicas brasileiras"(Santos - 1999).

Pilar do Sul teve sua história contada a partir de 1877, quando foi criada a freguesia do município de Sarapuí, com o nome de Nossa Senhora do Pilar. Os primeiros povoadores de Pilar do Sul eram homens que desbravavam as matas em busca de minérios e praticavam a caça, entre eles João Batista Ribeiro, fundador da Vila Pilar, hoje o centro da cidade. Assim, a localidade caracterizou-se, primitivamente, como ponto de partida de caçadores vindos principalmente do bairro da Ilha, no município de Sorocaba. O antigo povoado de Pilar contava com uma estrutura bastante precária, comum a lugares de trânsito cujo principal atributo era atender às necessidades dos preparativos das montarias (www.seade.gov.br). 
Em 12 de maio de 1891, a freguesia foi elevada à categoria de vila. A cidade, no entanto, permaneceu estacionada durante muitos anos, porque, na época das chuvas, suas estradas ficavam intransitáveis, impedindo que a produção agrícola local fosse escoada. Teve sua autonomia definitiva como Município a partir de 1936, mas sua atual denominação só foi adotada em 30 de novembro de 1944.

A origem do nome tem duas versões: uma, devido às grandes pedras em formato de pilões, as quais eram usadas por caçadores para "piloar" a carne da caça; outra versão, devida à devoção do povo pela Santa Nossa Senhora do Pilar, imagem trazida por mineiros (www.pilardosul.sp.gov.br).

O crescimento de Pilar do Sul só foi possível quando o sistema rodoviário que atravessa o seu território foi desenvolvido, possibilitando que os setores agrícola, pecuário e industrial se desenvolvessem.

A cidade ocupa uma das colinas mais suaves da região centro-Norte do Município, obedecendo ao tradicional traçado em tabuleiro de xadrez e, mesmo ao se expandir para áreas circunvizinhas mais acidentadas, não fugiu à regra. A capital regional Sorocaba, distante $43 \mathrm{~km}$ de Pilar do Sul, oferece, além de trabalho para alguns moradores, um vasto comércio, prestação de serviços e lazer, que complementam os setores menos desenvolvidos da cidade. A Foto 1 apresenta uma visão geral da cidade de Pilar do Sul. 


\section{1 - Aspectos Físico-Naturais}

O Município de Pilar do Sul encontra-se numa faixa de transição do Planalto Atlântico para a Depressão Periférica Paulista, apresentando características geomorfológicas específicas em cada Unidade Morfoescultural (Ross, J.L.S). Os contatos geológicos e morfológicos, cuja linha divisória corta o Município no sentido Nordeste-Sudoeste, estabelecem dois domínios de formas de relevo, solo, clima e vegetação, que imprimem contrastes nas paisagens e diferenças nas atividades econômicas.

A Sudeste, o Planalto Atlântico, segundo AB'SÁBER (1970), pertencente ao "Domínio das regiões serranas, tropicais úmidas, ou dos mares de morros extensivamente florestados" e, a Noroeste, a Depressão Periférica Paulista classificada pelo mesmo autor como "Faixa de Transição". Na Foto 2, pode-se observar o relevo de "mar de morros", atualmente sem a vegetação natural, somente ocupada com a plantação de eucaliptus.

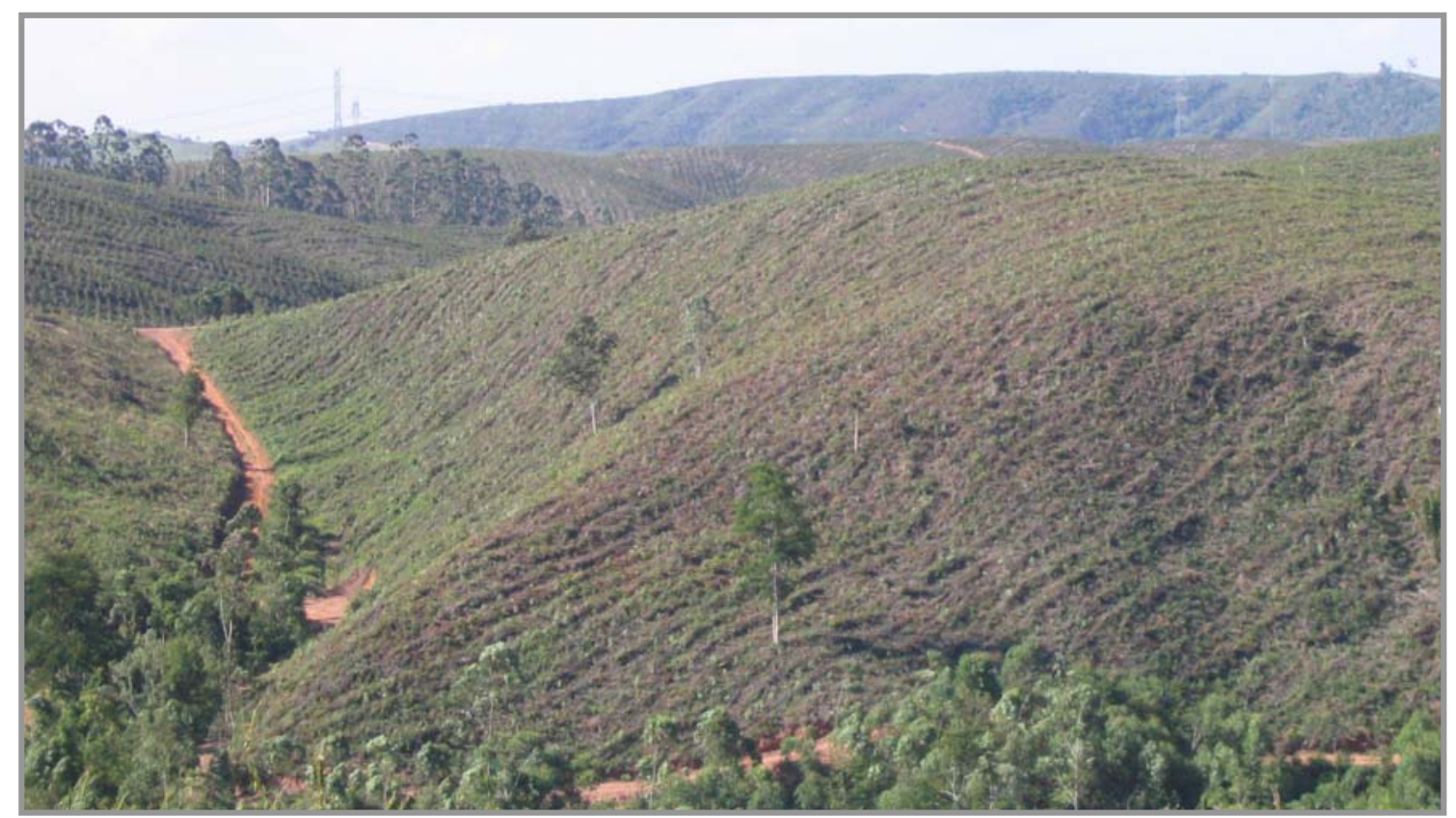

Foto 2: Área de Silvicultura recém cortado em relevo de "mar de morros".

Foto: Eduardo Reis Rosa, 2005 
De acordo com Almeida (1974), o Planalto Atlântico é constituído de rochas cristalinas datadas do Pré-Cambriano Superior, apresentando rochas graníticas e filitos do Grupo São Roque, associados a quartizitos, metabasitos, gnaisses e migmatitos, entre outras, que assumem importância local. O Planalto Atlântico Ocidental compreende uma "estreita e elevada faixa montanhosa, longa de $220 \mathrm{~km}$ e com cerca de 5200 km2, que encima a Serra de Paranapiacaba, separando a Província Costeira da Depressão Periférica a Oeste do Planalto de Ibiuna" (Almeida, 1974).

Uma visão geral do Município pode ser obtida pela Figura 10 que apresenta o Mapa Topográfico da área de estudo. 


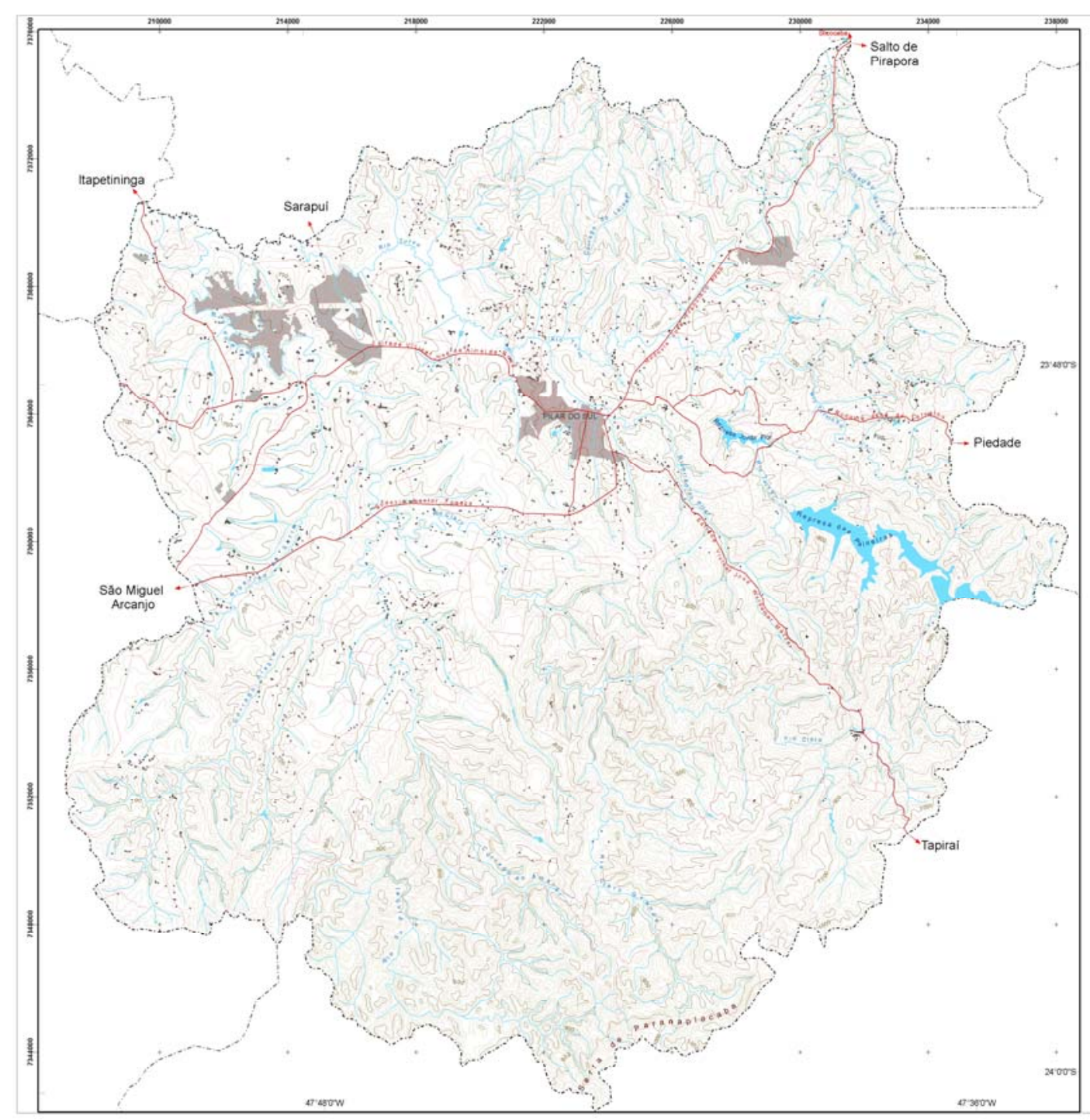

Figura 10 Mapa Topográfico
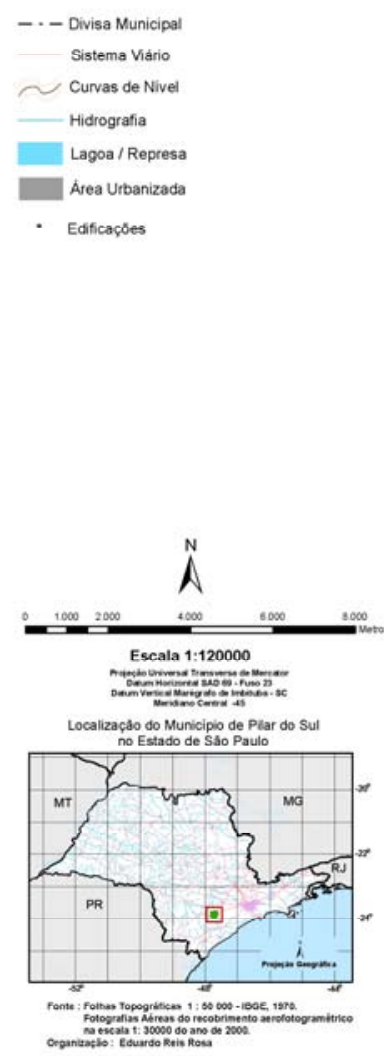
O Planalto Atlântico, sem dúvida, constitui a unidade de maior expressão em altitudes, representadas por regiões serranas de topografia mamelonar, que variam de 800 a 1100 metros, com relevo acidentado com topos convexos e formas muito dissecadas, com grau de entalhamento dos vales de até 130 metros, apresentando dimensão interfluvial média entre 250 a 750 metros e alta densidade de drenagem, sujeitos a processos erosivos agressivos, com probabilidade de ocorrência de movimentos de massa e erosão linear em sulcos e voçorocas (Ross, J. L. S. \& Moroz, I. C. - 1997). No município de Pilar do Sul, essa região encontra-se ao Sul, na Serra de Paranapiacaba.

No topo da Serra de Paranapiacaba e na região sudeste do Planalto Atlântico no Município, aparecem formas de relevo com dimensões interfluviais médias maiores e menor grau de entalhamento dos vales. Dessas áreas elevadas do Planalto Atlântico, surge uma farta rede de drenagem, que se dirige sistematicamente para Norte e Noroeste em busca da Depressão Periférica. Os rios têm suas cabeceiras apoiadas nos altos da Serra de Paranapiacaba, apresentam fortes gradientes, cursos perturbados por numerosos acidentes rochosos e são tributários do Rio Itapetininga (Bacia do Paranapanema). O Rio Turvo, em particular, apresenta trechos onde a rocha granítica aflora, resultando em corredeiras e cachoeiras. A única drenagem que escapa a esta condição é constituída pelo Rio Sarapuí, que tem seus afluentes localizados a Nordeste do Município e suas águas são drenadas para a bacia do Rio Sorocaba (Tietê).

O Mapa Hipsométrico (Figura 11) identifica as variações altimétricas do relevo no Município. No mapa, percebe-se que a transição do Planalto Atlântico para a Depressão Periférica segue os limites variando entre 700 a 800 metros de altitude. A Sudeste do Município, identificam-se as regiões mais elevadas, onde pode-se observar o domínio das maiores altitudes, chegando a altitudes superiores a 1000 metros, correspondente ao topo da Serra de Paranapiacaba. A Noroeste, aparecem regiões mais baixas da Depressão Periférica, com altitudes próximas aos 600 metros. 


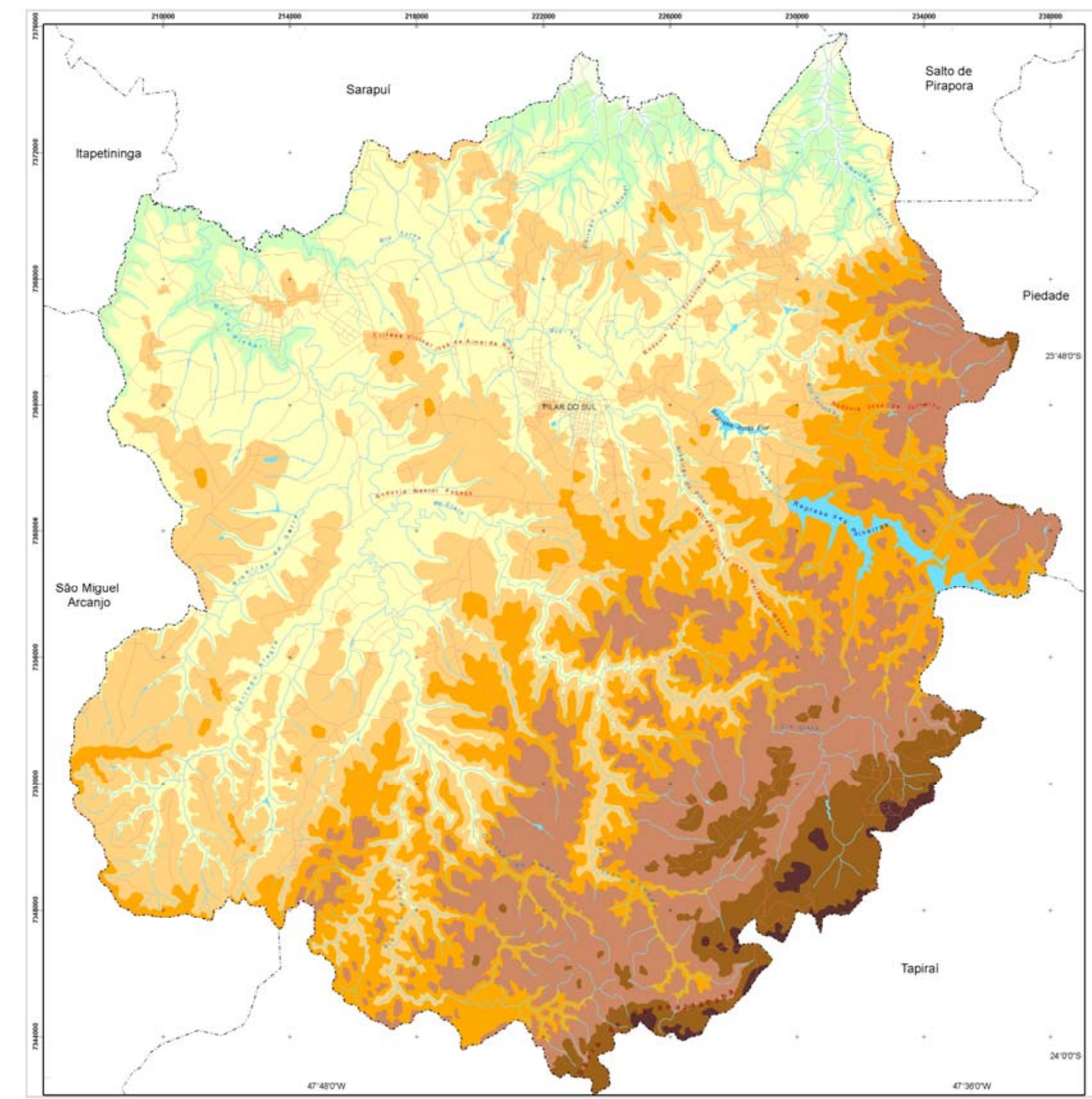

Figura 11

Mapa Hipsométrico

Classes Hipsométricas

1 $>1000 \mathrm{~m}$

$900-1000 \mathrm{~m}$

$800-900 \mathrm{~m}$

$750-800 \mathrm{~m}$

$700-750 \mathrm{~m}$

$650-700 \mathrm{~m}$

$600-650 \mathrm{~m}$

$<600 \mathrm{~m}$

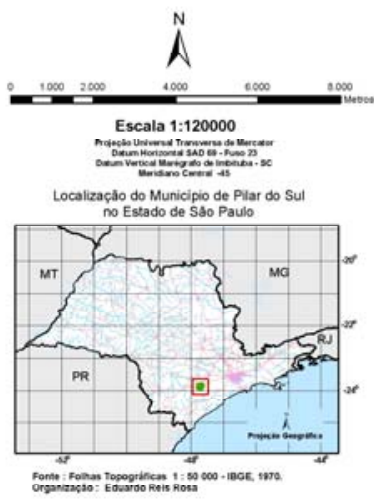


Como unidade rebaixada entre o Planalto Atlântico e as cuestas basálticas do relevo paulista, identifica-se a Depressão Periférica Paulista, datada do Período Permiano Carbonífero, que, em Pilar do Sul, é representada pela Depressão Paranapanema, com litologias dominantes de arenitos eólicos e arenitos. À medida que se avança para o Noroeste do Município, encontra-se um relevo mais suave que avança em direção à Depressão Periférica. Em Pilar do Sul, encontramos, marcadamente, uma transição do escudo cristalino para a bacia sedimentar, onde a estrutura granítica vem sendo descoberta do capeamento carbonífero (Almeida 1974).

Com modelado de dissecação em desníveis bem menores que os verificados no Planalto Atlântico, a Depressão Paranapanema possui altitudes que variam de 600 a 700 metros, apresentando um relevo de denudação, com formas de topo tabulares ou planos, com densidade de drenagem média a alta, grau de entalhamento dos vales menores que 70 metros, dimensão interfluvial média variando entre 750 a 1750 metros, sendo áreas sujeitas a forte atividade erosiva. O relevo em geral torna-se mais suave no Noroeste, direção preferencial da rede de drenagem.

A região do Município no extremo Nordeste, na divisa com Sarapuí, Salto de Pirapora e Piedade, situada no divisor de águas entre os rios Turvo e Sarapuí, é conhecida como Serra dos Lopes. Esta área caracteriza uma rampa de mergulho mais resistente aos processos erosivos da transição do Planalto Atlântico para a Depressão Periférica (AB'SABER - 1969). Com relevo de formas denudacionais de colinas com topos convexos, apresenta uma dissecação mais intensa que as identificadas na Depressão Paranapanema e vales de entalhamento menor do que as identificadas no Planalto Atlântico. As altitudes variam entre 600 e 800 metros e as dimensões interfluviais médias são menores que 250 metros, estando sujeitas a processos erosivos agressivos, inclusive com movimentos de massa.

A Foto 3 ilustra a morfologia do relevo da Depressão Paranapanema no Município. 
A classificação e o mapeamento da inclinação do terreno como um atributo e qualificação do relevo, é indispensável nos estudos sobre uso da terra e constitui elemento fundamental para o levantamento das potencialidades de uso. O Mapa Clinográfico representa as variações topográficas da superfície do terreno e constitui uma das variáveis para este estudo, onde o principal elemento é a vertente (De Biasi - 1970).

As Figuras 12 e 13 ilustram a espacialização das classes clinográficas sobre um modelo digital de terreno, com a fotografia aérea como plano de textura.

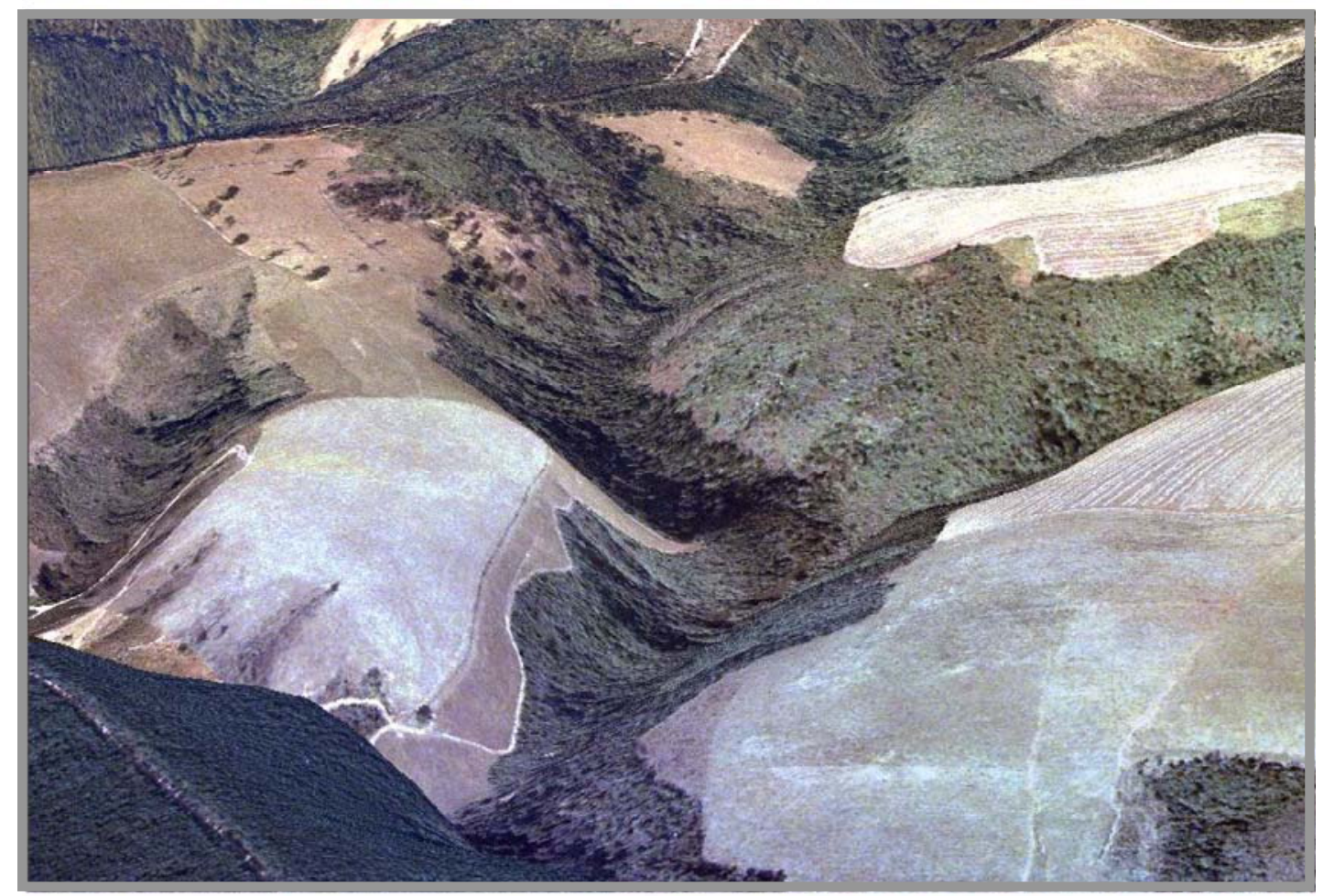

Figura 12 - Visualização tridimensional do terreno com plano de textura de fotografia aérea. 


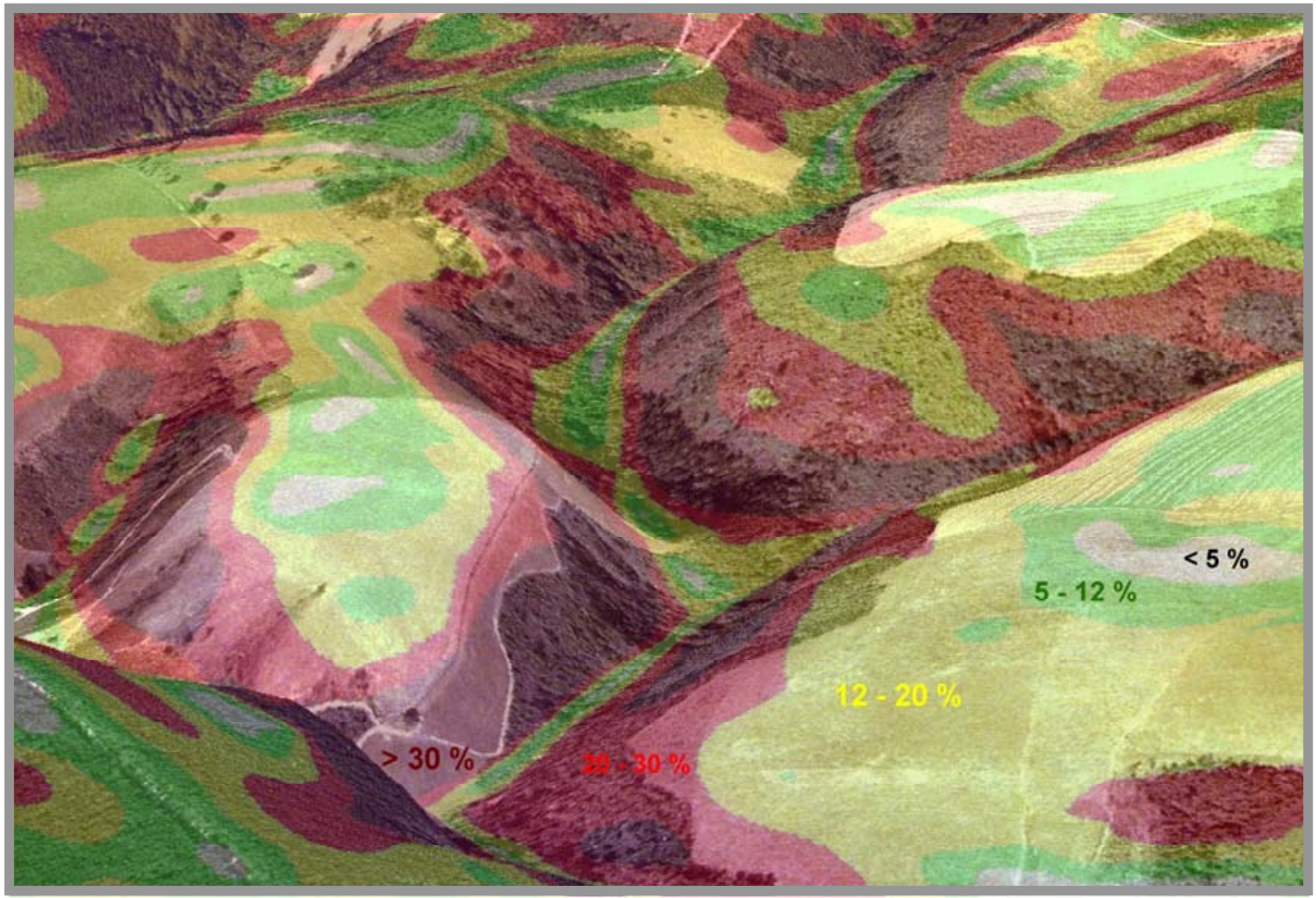

Figura 13 - Classes Clinográficas com transparência sobreposta à visualização tridimensional de fotografia aérea.

A Figura 14 mostra o Mapa Clinográfico, onde se observam as maiores declividades na região do Planalto Atlântico e as declividades menos acentuadas, na região da Depressão Periférica. 


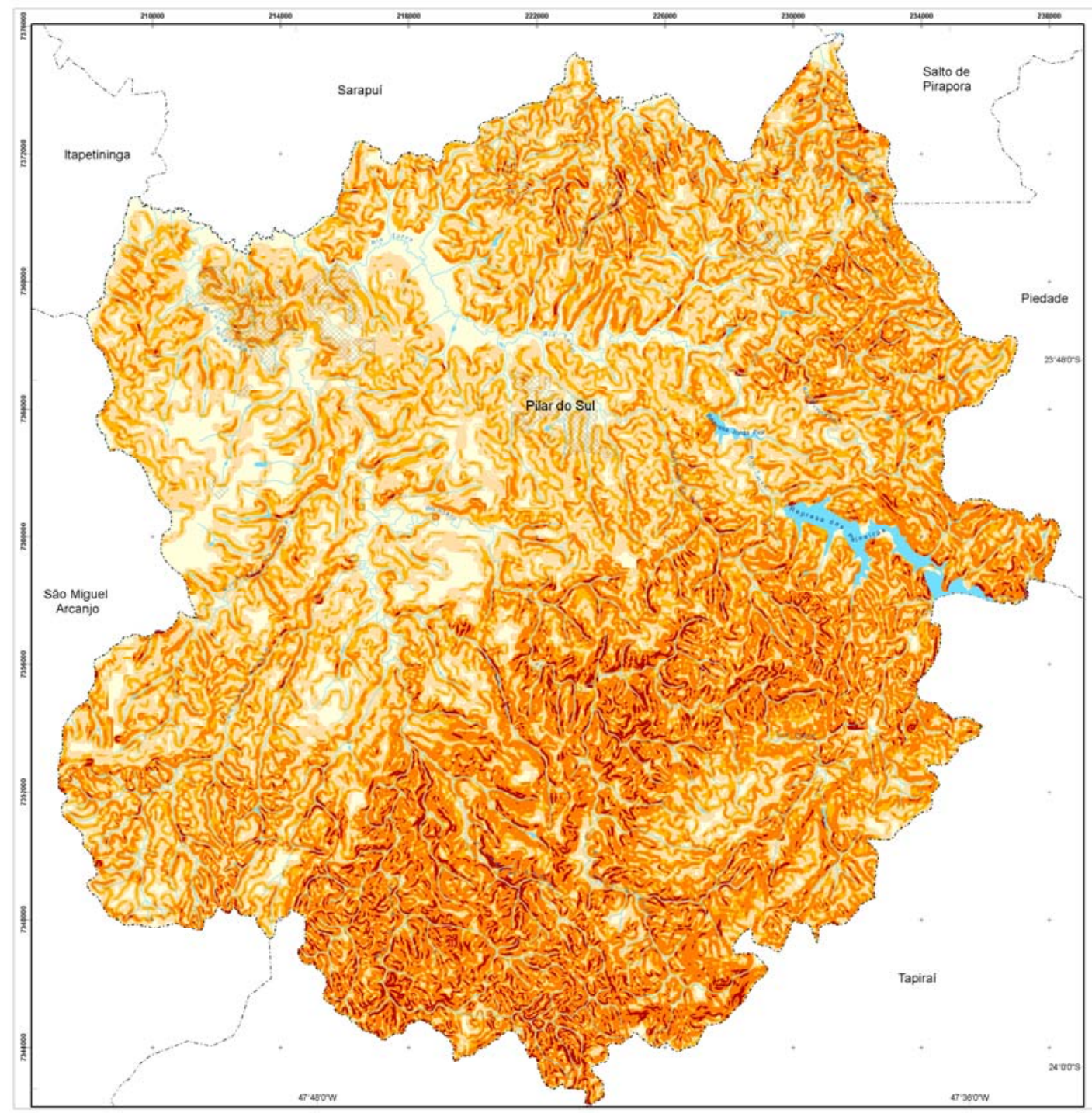

Figura 14

Mapa Clinográfico

-- Divisa Municipal
Hidrografia
Lagoa / Represa
Mrea Urbanizada

Classes Clinográficas

\begin{tabular}{|l|l|}
\hline$<2 \%$ \\
\hline 2 a $12 \%$ \\
\hline 12 a $20 \%$ \\
\hline 20 a $47 \%$ \\
\hline$>47 \%$ \\
\hline
\end{tabular}

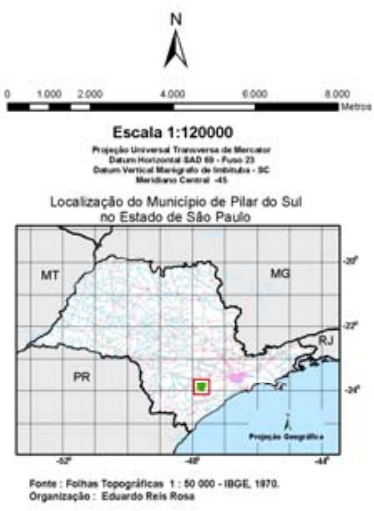


O Mapa Geomorfológico apresenta uma síntese dos aspectos geológicos e pedológicos, e é a base para a análise descritiva das vertentes, a partir dos aspectos do relevo caracterizados pelos mapas Hipsométrico e Clinográfico. As unidades geomorfológicas foram detalhadas com auxílio da imagem de Radar e do mosaico de fotografia aérea (escala 1:30000), definindo os limites que representam as desigualdades morfológicas do relevo.

$\mathrm{Na}$ Depressão Paranapanema, os comprimentos de rampa têm maiores extensões, variando de 300 a 2500 metros (média de 700 metros), porém as diferenças altimétricas são menores que 70 metros. No Planalto Atlântico, os comprimentos de rampa são, em sua média, menores (400 metros), mas as diferenças altimétricas chegam a até 130 metros. Nos processos erosivos, o tamanho e a quantidade do material em suspensão arrastado pela água dependem da velocidade com que ela escorre, que, por sua vez, é uma resultante do comprimento do lançante e do grau de declividade do terreno (Bertoni \& Lombardi Neto - 1990). Nas altas declividades, a resistência ao escoamento é menor, fazendo com que a velocidade da água aumente, diminuindo o processo de infiltração das águas no solo. Dessa forma, é possível identificar que o potencial erosivo na Depressão Paranapanema é menor que no Planalto Atlântico.

As Figuras 15, 16, 17 e 18 apresentam medidas ilustrativas e comparativas no Planalto Atlântico e na Depressão Periférica. 


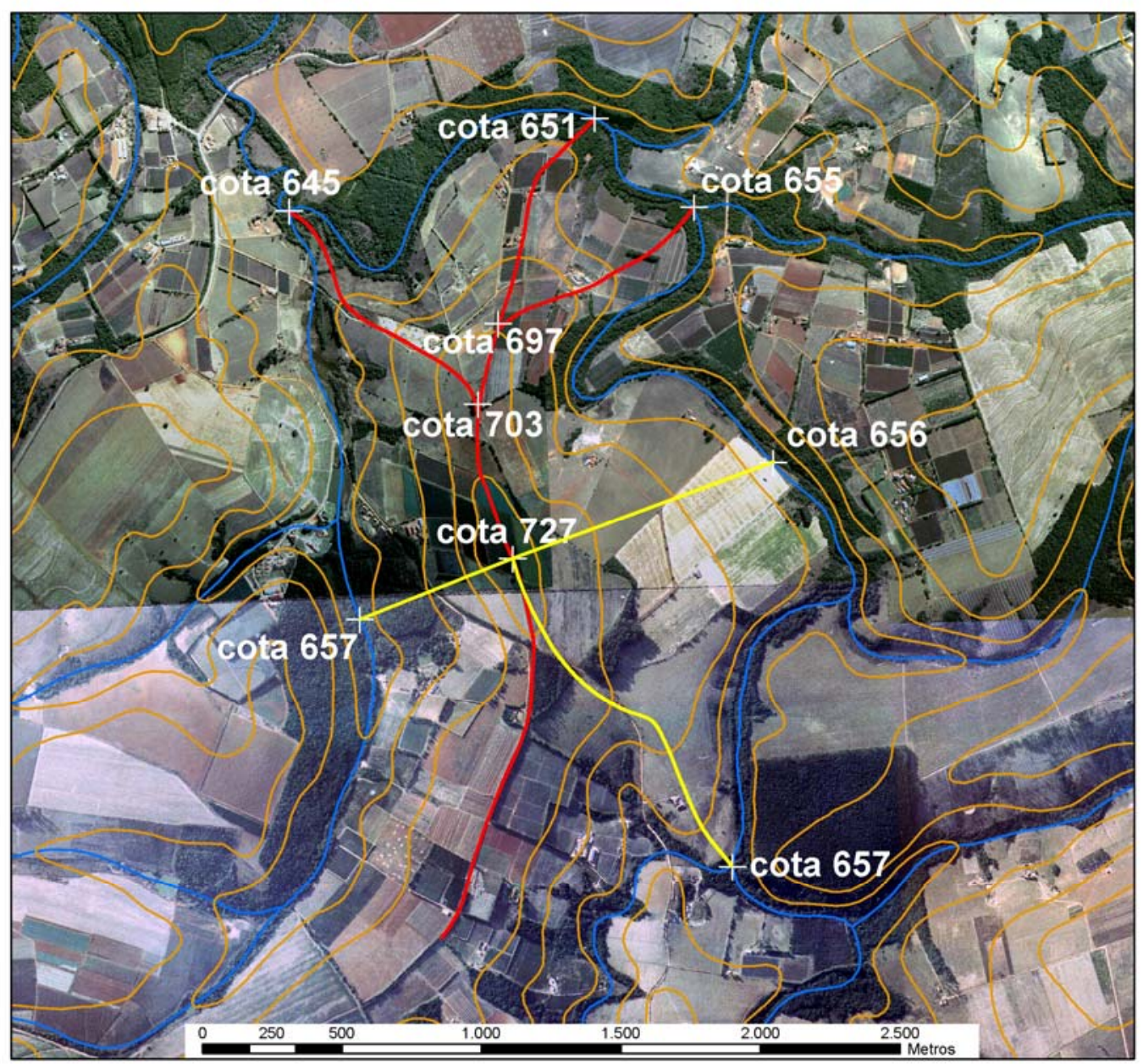

Figura 15 - Base topográfica com medidas explicativas das diferenças altimétricas no relevo da Depressão Periférica.

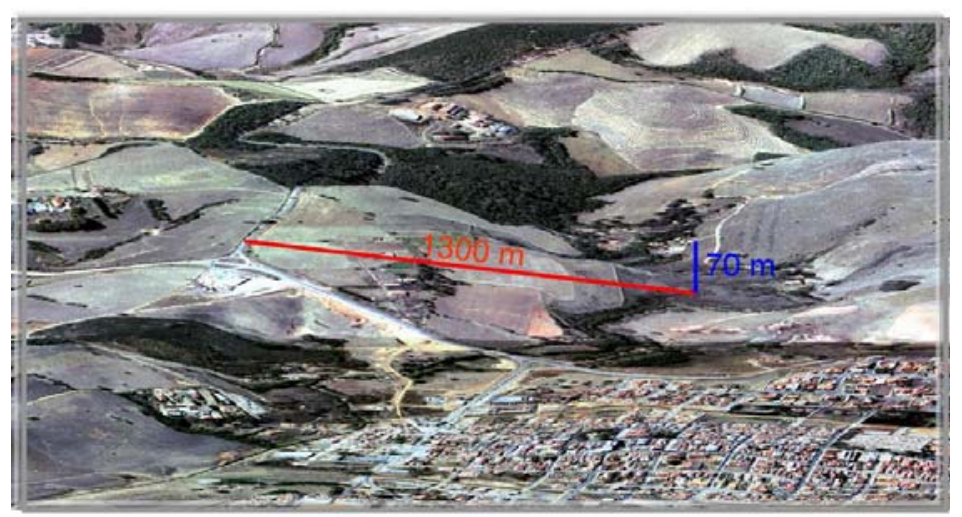

Figura 16 - Visualização tridimensional da Depressão Periférica com medidas explicativas de comprimento de rampa e diferença altimétrica. 


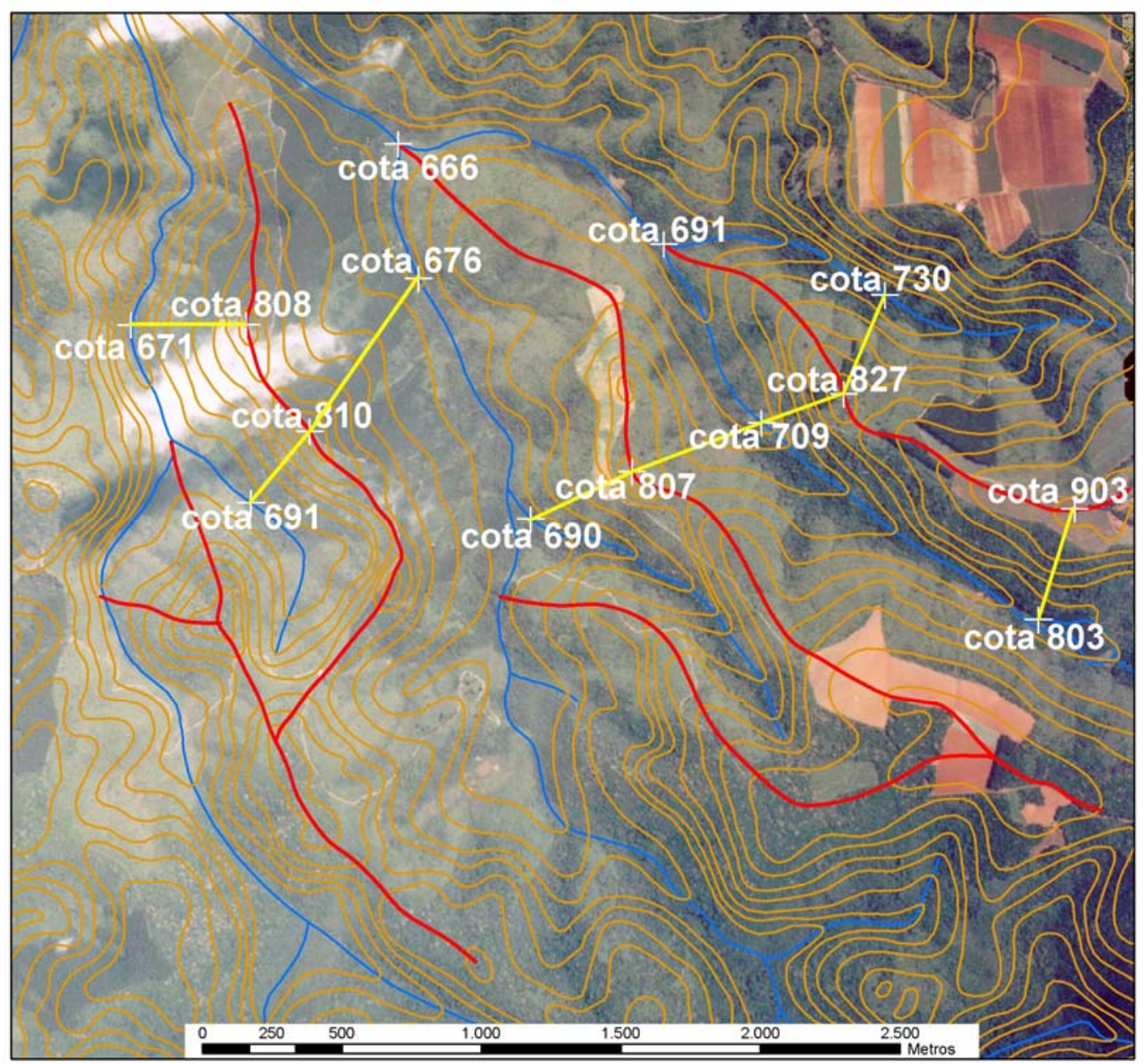

Figura 17 - Base topográfica com medidas explicativas das diferenças altimétricas no relevo do Planalto Atlântico.

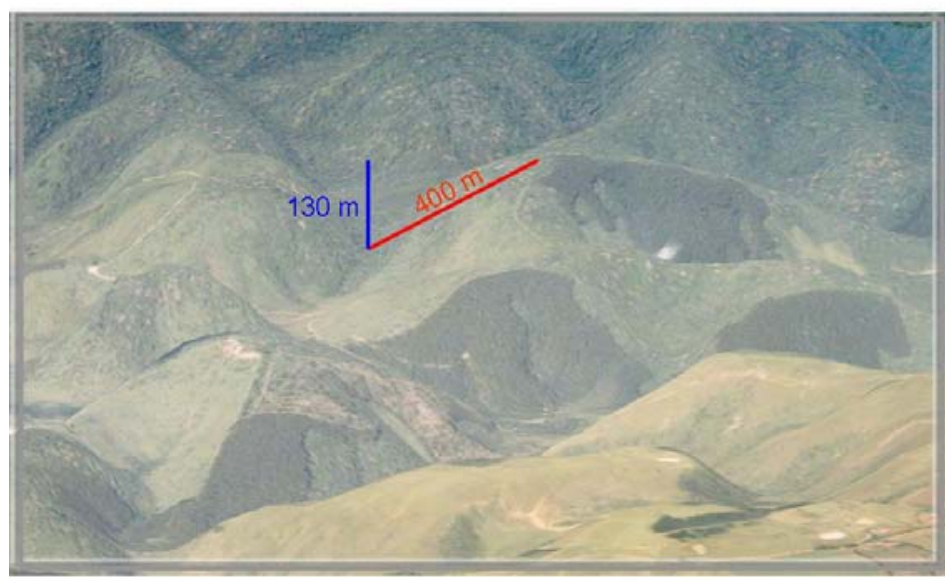

Figura 18 - Visualização tridimensional do Planalto Atlântico com medidas explicativas de comprimento de rampa e diferença altimétrica. 
Os solos apresentam propriedades físico-químicas decorrentes da rocha matriz. O processo de formação dos solos, sua estrutura, propriedades e fertilidade são fundamentais para o entendimento das variações espaciais dos solos, seja em uma vertente ou na paisagem como um todo. A partir de uma visão integrada da interpretação da geomorfologia e das classes de solos, consegue-se entender a interdependência dos processos de formação e reacomodação, que determinam as condições e possibilidades de uso e manejo. A relação solos e relevo, assim como organização dos solos ao longo de uma vertente (análise estrutural da cobertura pedológica), é clássica do ponto de vista geomorfológico e pedológico. Porém, a individualização de alguns parâmetros e a intrínseca relação entre os diversos elementos do meio físico e suas dependências torna esta relação complexa.

Com base na análise das variações do relevo (geomorfologia), na litologia, na rede de drenagem superficial, na interpretação das fotografias aéreas e em mapeamentos de menor escala (IAC / EMBRAPA SOLOS - 1999), foi possível estabelecerem-se correlações para detalhamento das informações pedológicas.

Os solos da região do Planalto Atlântico são, em geral, classificados como Argissolos Vermelho-Amarelo Distróficos (valor de saturação por bases inferior a $50 \%$ na maior parte dos $100 \mathrm{~cm}$ iniciais do Horizonte B), de textura média (teor de argila $<35 \%$ e mais de $15 \%$ de areia). Os Argissolos apresentam um acréscimo de argila em profundidade, atribuindo a esses solos um horizonte $B$ textural, que, em condições de mudança textural abrupta, são mais suscetíveis à erosão. Para utilização agrícola, é necessária a construção de terraços em nível, pois são solos com baixa ou muito baixa resistência à erosão. Os Argissolos são, na sua maioria, solos profundos, não apresentando impedimento físico à penetração do sistema radicular. A presença de saprolitos, no entanto confere a esses solos uma importante zona de reserva potencial de nutrientes.

No Planalto Atlântico, as correlações com aspectos do relevo identificam solos do tipo Latossolos, em áreas com declividade $<8 \%$ e em áreas com declividade $>47 \%$, favorável à presença de solos do tipo Cambissolos Háplicos, com argila de atividade baixa (CTC<27 $\mathrm{cmol}_{\mathrm{c}} / \mathrm{Kg}$ argila) e distróficos e Neossolos Litólicos. 
Na Depressão Paranapanema, existe a predominância de Latossolos Vermelho Distróficos, associados à Latossolos vermelho-amarelos distróficos, ambos A moderado (horizonte $A$, em geral, moderadamente espesso, $<25 \mathrm{~cm}$ e/ou com teores médios de matéria orgânica), textura argilosa (teor de argila $>35 \%$ ). O caráter distrófico é a principal limitação, pois reflete a baixa capacidade de disponibilizar nutrientes às plantas. No entanto, uma vez eliminadas tais limitações, esses solos tornam-se bastante produtivos.

De forma geral, os solos presentes na Depressão Paranapanema (Latossolos) possuem maior resistência à ocorrência de processos erosivos, uma vez que possuem horizontes mais espessos e maior capacidade de infiltração das águas superficiais, por possuir uma porosidade total com valores de $50-60 \%$. Os Latossolos, em geral, são solos com boas propriedades físicas e favoráveis ao uso intensivo de máquinas agrícolas.

A correlação de aspectos do relevo na Depressão Paranapanema com a variação de classes de solo identifica áreas com declividades acima $20 \%$, onde ocorre a formação de solos do tipo Argissolos Vermelho-Amarelo e em áreas de declividade $<2 \%$ nas planícies aluviais, onde existe uma predominância de solos hidromórficos.

Os solos destinados aos cultivos agrícolas são ricos em matéria orgânica e nitrogênio, apresentando ph na faixa dos 5 aos 6, caracterizando solos ácidos, pobres em fósforo, com teores de cálcio $X$ magnésio baixo e presença de alumínio e fósforo em teores médios (IAC - 1973). Em geral, são solos de média a baixa fertilidade e necessitam de calagem e adubação para a sua exploração. Segundo Lombardi Neto e Bertoni (1975), os Latossolos apresentam boa tolerância à perda por erosão, com boa permeabilidade interna e associados a relevo pouco declivoso.

A Figura 19 apresenta o Mapa Geomorfológico, que incorpora informações de Geologia e Pedologia. 


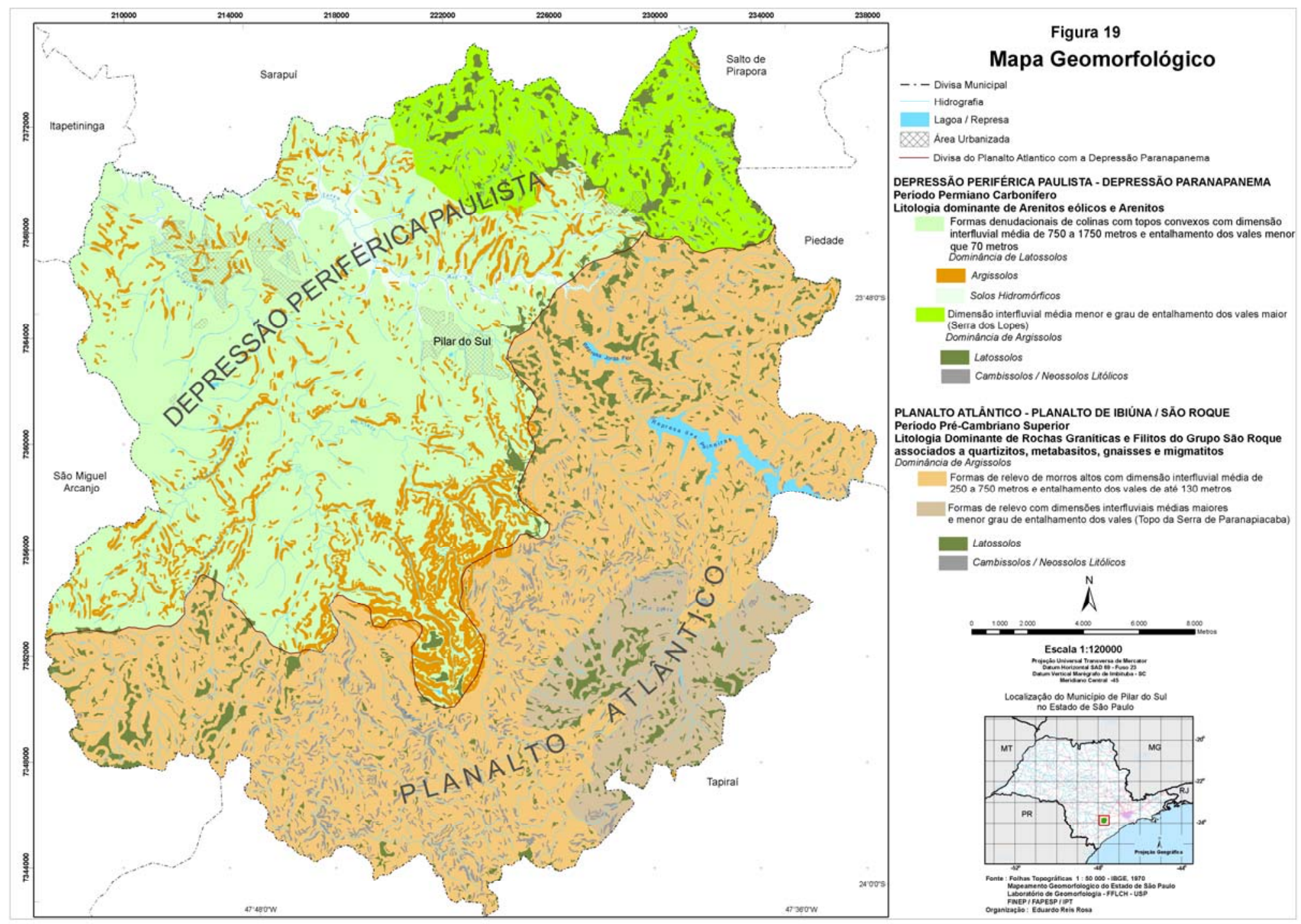


Os recursos hídricos são de grande importância para o Município, sendo os principais representantes da hidrografia os rios Turvo, Claro e o Pinhal, todos com suas nascentes no Planalto Atlântico, em áreas de relevo acidentado da Serra de Paranapiacaba, afluentes do Rio Itapetininga, que é tributário do Rio Paranapanema. A Serra de Paranapiacaba ocupa uma área aproximada de 200 $\mathrm{km}^{2}$, e sua linha principal de cumeadas tem aproximadamente $40 \mathrm{~km}$ de extensão (SANTOS, E.O. - 1999).

O Rio Turvo, em especial, é o mais extenso deles e possui a Represa das Paineiras e a Jorda Flor, onde funcionam usinas hidroelétricas. O posto fluviométrico do rio Turvo registra vazões de menos de $5 \mathrm{~m}^{3} / \mathrm{seg}$. nos meses mais secos e, freqüentemente, de mais de $80 \mathrm{~m}^{3} / \mathrm{seg}$. nos meses mais chuvosos (DAEE 1997).

Embora a região de Pilar do Sul quanto ao aspecto climático seja considerada sob diferentes denominações pelos diversos autores que se detêm na análise do tema (Martonne - 1944; Setzer - 1949; Monteiro - 1973; Ross - 1966), optamos pela classificação de Azevedo (1968), segundo a qual, o Município encontra-se na área de transição entre os dois tipos de clima subtropical, de acordo com a classificação de Köppen: Cfa na porção Norte-Noroeste do Município e Cfb ao Sul-Sudeste.

O clima Cfa é subtropical, com verão quente e úmido, sem estação seca, com temperatura do mês mais quente superior a $22^{\circ} \mathrm{C}$ e do mês mais frio, com média inferior a $18^{\circ} \mathrm{C}$. Nos meses mais secos (julho/agosto), a pluviosidade situa-se entre 30 e $60 \mathrm{~mm}$.

O clima Cfb apresenta características semelhantes, apenas diferenciando-se quanto ao verão um pouco mais brando, devido à influência da altitude, apresentando a temperatura média do mês mais quente inferior a $22^{\circ} \mathrm{C}$ (Setzer 1949).

No Município encontram-se instalados três postos pluviométricos (DAEE - 1977):

- Usina Batista - localização: 230 50' S e 470 39' W Gr. Altitude: 710 m. Dados a partir de 1945, embora alguns incompletos ou apresentando inconsistências, sendo aproveitáveis após 1957. 
- Fazenda Moquém - localização: 23 55' S e 470 42' W Gr. Altitude: 890 m. Dados a partir de 1972.

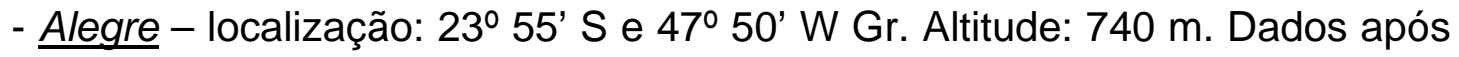
1972.

Pinto, Ortolani \& Alfonsi elaboraram tabelas de temperaturas em função da latitude e altitude no Estado de São Paulo, que permitem estimar as temperaturas médias para o Município de Pilar do Sul. De acordo com esses estudos, as médias situam-se em $19^{\circ}$ para as altitudes menores que 700 metros, $18^{\circ}$ para as altitudes em torno de 850 metros e $17^{\circ}$ para 1050 metros, que correspondem aos pontos mais elevados do Município.

Considerando-se julho o mês mais frio e fevereiro, o mais quente, têm-se, em resumo, os dados na Tabela 1 que se segue:

Tabela 1: Temperaturas Médias do Município de Pilar do Sul.

Latitude média: $23^{\circ} 30^{\prime} \mathrm{S}$.

\begin{tabular}{|c|c|c|c|}
\hline Altitude & Fevereiro & Julho & Média Anual \\
\hline $600 \mathrm{~m}$ & $22,8^{\circ}$ & $15,7^{\circ}$ & $19,6^{\circ}$ \\
\hline $650 \mathrm{~m}$ & $22,5^{\circ}$ & $15,4^{\circ}$ & $19,3^{\circ}$ \\
\hline $700 \mathrm{~m}$ & $22,2^{\circ}$ & $15,1^{\circ}$ & $19,0^{\circ}$ \\
\hline $750 \mathrm{~m}$ & $21,9^{\circ}$ & $14,9^{\circ}$ & $18,7^{\circ}$ \\
\hline $800 \mathrm{~m}$ & $21,6^{\circ}$ & $14,6^{\circ}$ & $18,4^{\circ}$ \\
\hline $850 \mathrm{~m}$ & $21,3^{\circ}$ & $14,3^{\circ}$ & $18,2^{\circ}$ \\
\hline $900 \mathrm{~m}$ & $21,0^{\circ}$ & $14,1^{\circ}$ & $17,9^{\circ}$ \\
\hline $950 \mathrm{~m}$ & $20,7^{\circ}$ & $13,8^{\circ}$ & $17,6^{\circ}$ \\
\hline $1000 \mathrm{~m}$ & $20,4^{\circ}$ & $13,5^{\circ}$ & $17,3^{\circ}$ \\
\hline $1050 \mathrm{~m}$ & $20,1^{\circ}$ & $13,3^{\circ}$ & $17,0^{\circ}$ \\
\hline
\end{tabular}

Organizado por: Eduardo Reis Rosa 
Estes dados, em adição às referências climáticas encontradas, permitem concluir que as diferenças de altitude interferem nas isotermas, causando uma diferença de, aproximadamente, $2^{\circ}$ na temperatura das maiores altitudes em relação aos locais mais baixos. Ao se considerarem as médias mensais, a diferença entre as médias do mês mais frio e as do mais quente situa-se em 7 graus.

Embora todo o Município tenha um clima relativamente úmido, a análise dos dados pluviométricos demonstra que a estação pluviométrica de Moquém, situada na área de morros cristalinos ao sul da Usina Batista, apresenta índices normalmente mais elevados. Isto resulta que o mapa de isoietas se apresenta em faixas escalonadas de pluviosidades crescentes de Norte para Sul, iniciando-se com 1200 a 1300 mm/ano e chegando ao extremo Sul com a faixa de 1500 a 2000 mm/ano.

Apesar da irregularidade dos valores mensais de chuva de um ano para outro, o que se observa é a maior intensidade pluviométrica nos meses de setembro a março, e a menor, de abril a agosto, meses mais frios, nos quais é comum a ocorrência de geada (especialmente em junho e julho).

O gráfico da Figura 20 mostra a distribuição da Pluviosidade Média Mensal para o período de 1973 a 1997 (25 anos) correspondente ao posto pluviométrico Alegre, que se apresenta em condição intermediária entre os outros dois (Batista menos úmido e Moquém, mais úmido). A Figura 21 mostra os dados relativos ao ano de 1977 do posto pluviométrico Alegre, que pode ser considerado um ano-padrão. 
Figura 20 : Pluviosidade Média Mensal: Período 1973 - 1997

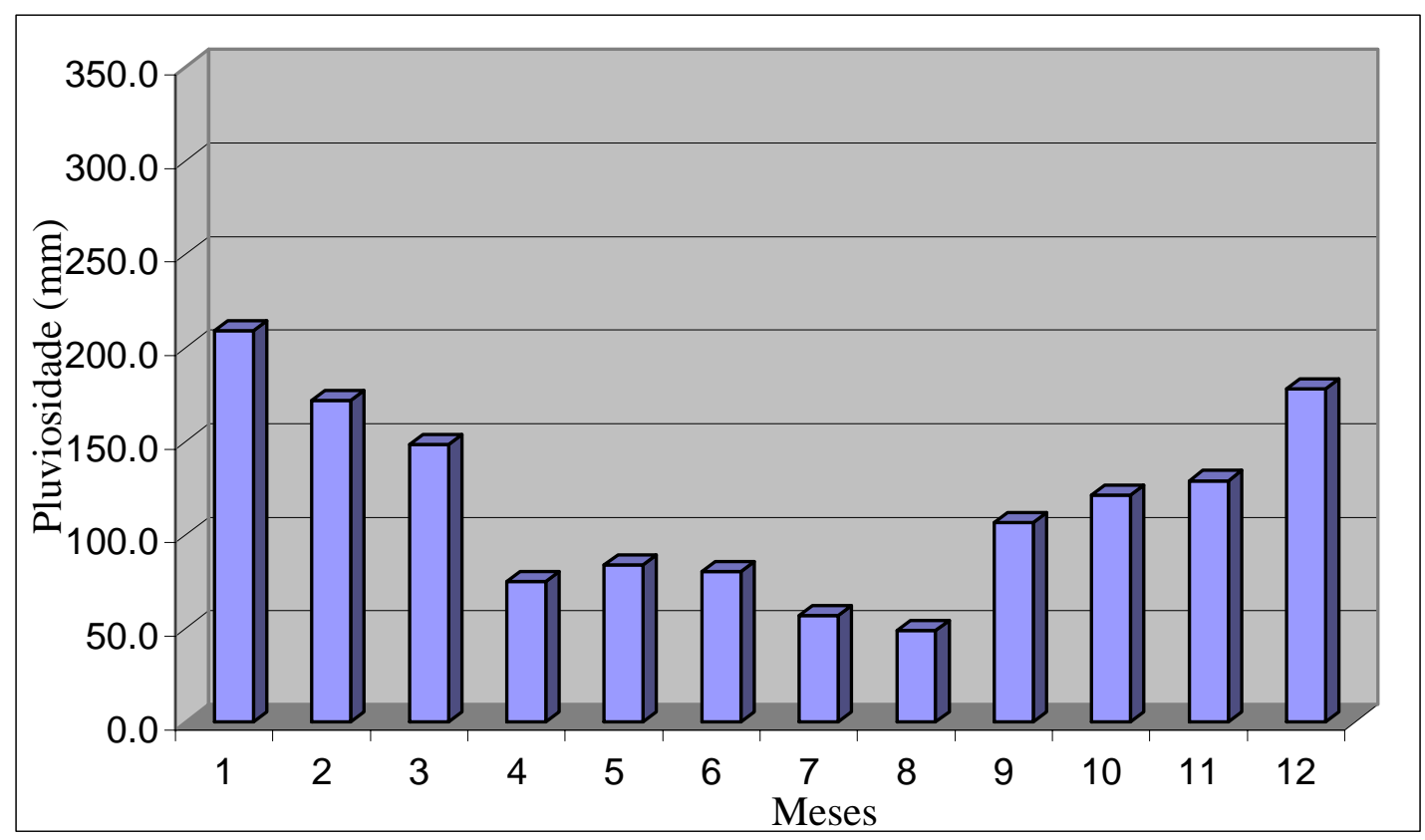

Fonte: DAEE, 1997

Organização: Eduardo Reis Rosa

Figura 21 : Pluviosidade Padrão: Ano de 1977

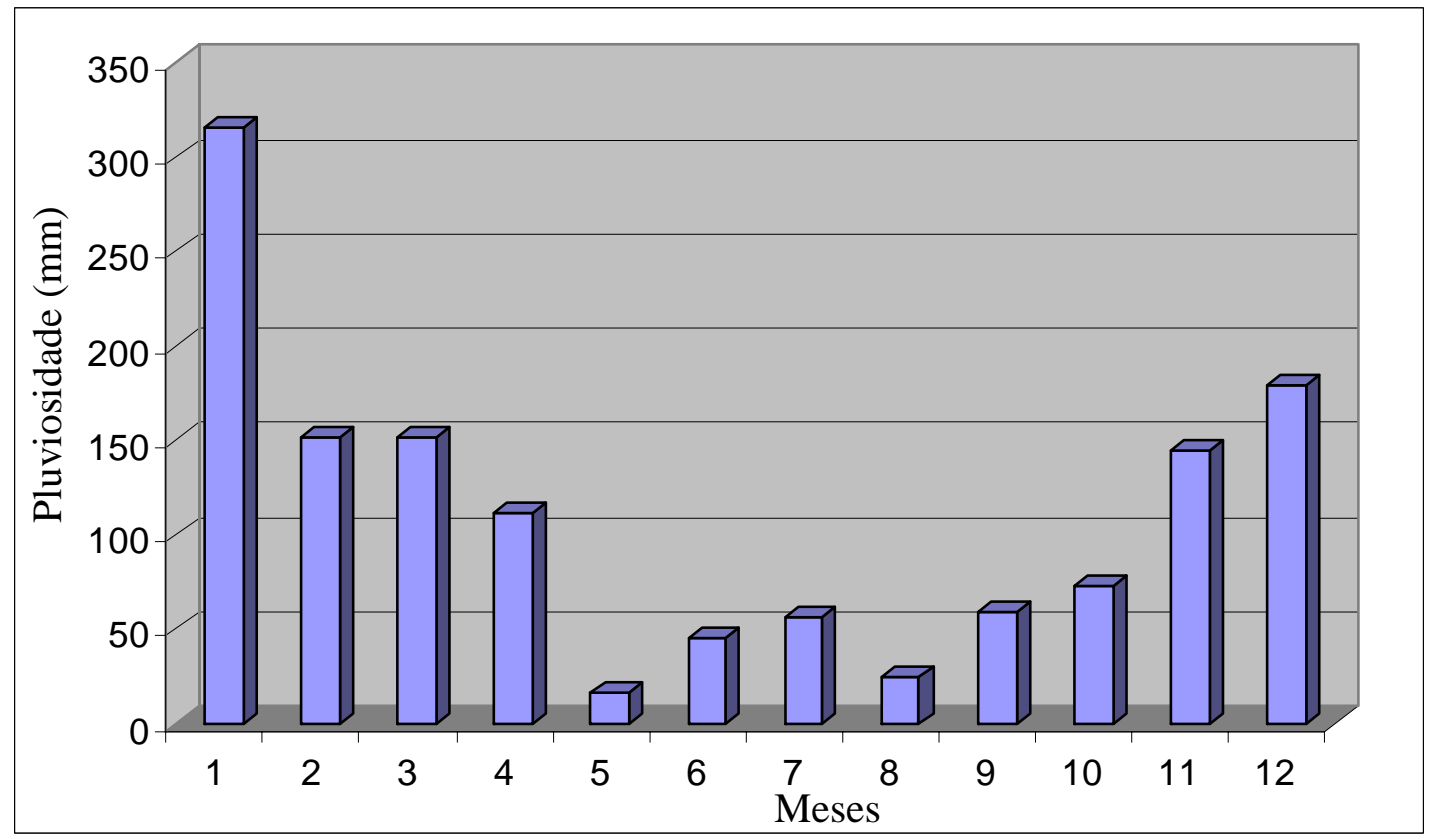

Fonte: DAEE, 1997

Organização: Eduardo Reis Rosa 
Os elevados índices pluviométricos do Município proporcionam uma evapotranspiração potencial segundo o método de "Thornthwaite \& Mather - 1955" da ordem de 900 a 1000 mm/ano, não apresentando deficiência hídrica. Ao contrário, a região Noroeste do Município apresenta um excedente hídrico de 300 a 500 mm e, ao Sul, 500 a 800 mm (Camargo - 1971).

Tais condições repercutem diretamente na agricultura, tornando as terras impróprias para grande parte dos cultivos anuais com bom nível técnico devido à excessiva umidade. Apenas o Noroeste do Município apresenta melhores condições do ponto de vista climático, embora ainda com umidade elevada e contínua, que pode causar problemas fito-sanitários nas culturas (Camargo - 1971). Alguns problemas provenientes dos aspectos climáticos podem ser resolvidos com a adoção de práticas de manejo. A caracterização climática, no entanto, demonstra que as operações com máquinas agrícolas devem levar em consideração os meses em que a concentração de chuvas é maior, uma vez que solos sem vegetação contribuem para a ocorrência de processos erosivos.

O Município de Pilar do Sul encontra-se na área de transição entre a Floresta Latifoliada Tropical e a Mata dos Pinhais ou de Araucárias, fato explicado pelas condições climáticas e de relevo da região.

Ab'Saber (1973), ao caracterizar o Domínio dos "mares de morros" florestados, entre outras características específicas do relevo, salienta a presença de "florestas tropicais recobrindo a área, primariamente, por mais de 95\% do espaço total. Enclaves de bosques de Araucárias em altitude e de cerrados em diversos compartimentos inferiores dos planaltos interiores, onde predominam chapadões florestados (sub-denominados mares de morros)".

À latitude de $23^{\circ} 30^{\prime} \mathrm{S}$ e com altitudes que ultrapassam os 1000 metros, as ocorrências de Araucárias se mesclavam à Floresta Tropical que dominava desde as margens dos rios até o topo dos morros mais baixos. Azevedo (1971) considera que, ao "estudarmos a área de ocorrência dos pinheirais, vemos que de Sul para Norte a altitude em que se acham é cada vez mais elevada. Se no Rio Grande do Sul podem ser encontradas a partir dos 500, ou ainda 400 metros, caminhando-se 
para Santa Catarina e Paraná as cotas em geral sobem a 500 e 600 metros, chegando-se a São Paulo alcançam a mais de $800 . . . "$.

Nas duas formações vegetais existem espécies comuns, o que levou Azevedo (1971) a dizer:

"Embora predominem os altos e esbeltos pinheiros, não é a floresta aciculifoliada, de modo algum, homogênea. Abaixo das elevadas copas de araucárias, vários outros elementos latifoliados se acham frequentemente associados, variando um pouco as espécies de uma região para outra."

A vegetação original praticamente não mais existe. Ao longo do tempo foi substituída pela agricultura, pastagem e pela silvicultura, que na porção Sul do Município, é bastante significativa. Há remanescentes de matas ciliares representados por corredores de vegetação arbórea (Figura 22) e arbustiva, que acompanham os trechos inferiores e mais íngremes das vertentes, e pequenas manchas de vegetação natural relativamente preservada, nas quais ocorrem, além das espécies originais da antiga mata, um grande número de palmeiras e, eventualmente, alguns exemplares de Araucária.

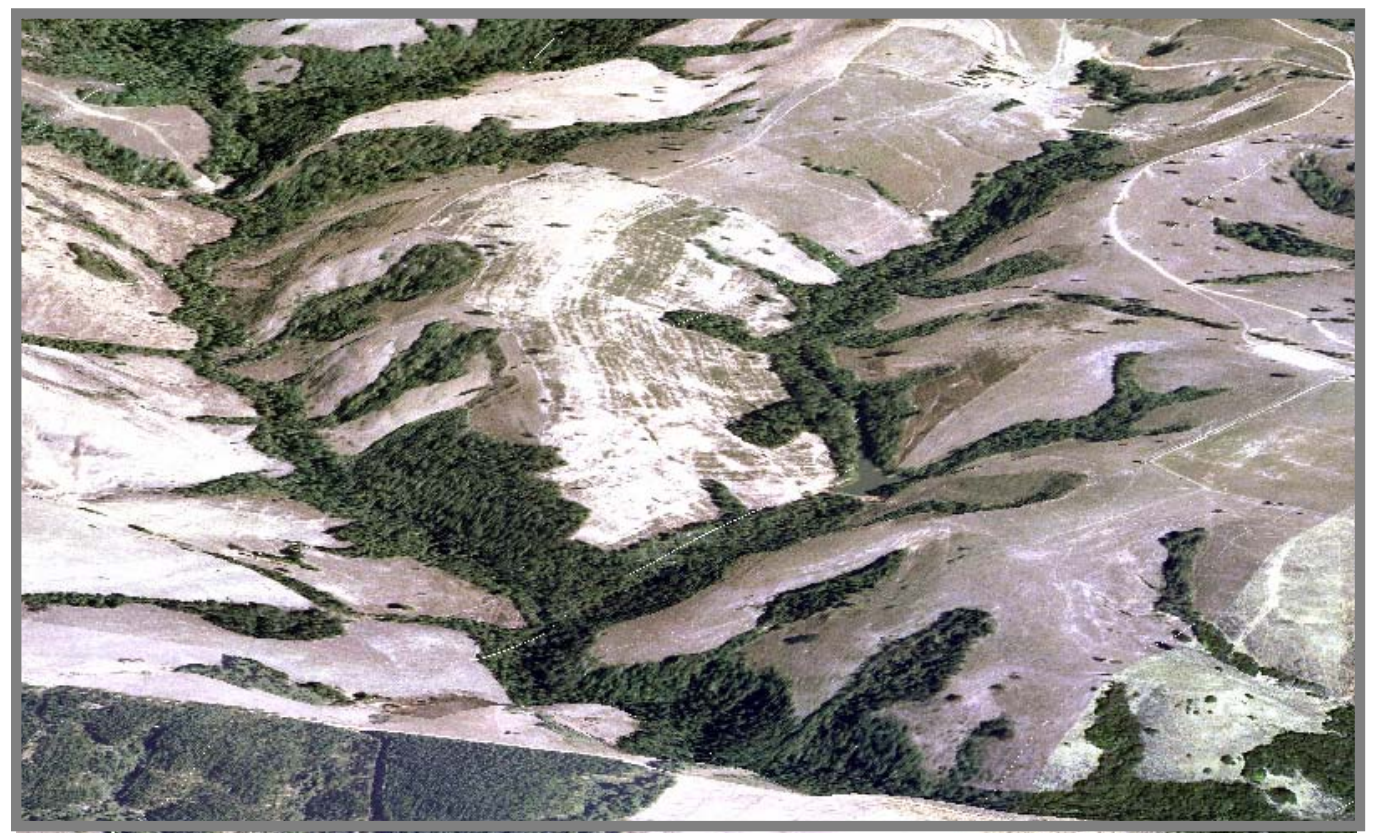

Figura 22 - Visualização tridimensional de áreas com Mata Ciliar 
Mesmo as matas ciliares que deveriam ser preservadas são constantemente sujeitas à derrubada para finalidade agrícola e submetidas à desfiguração pelo pastoreio e, ainda não raramente, vítimas do fogo, sofrendo sucessivos processos de degradação. A Foto 4 ilustra a região Sul do Município com a presença da silvicultura e de alguns fragmentos de Mata Atlântica.

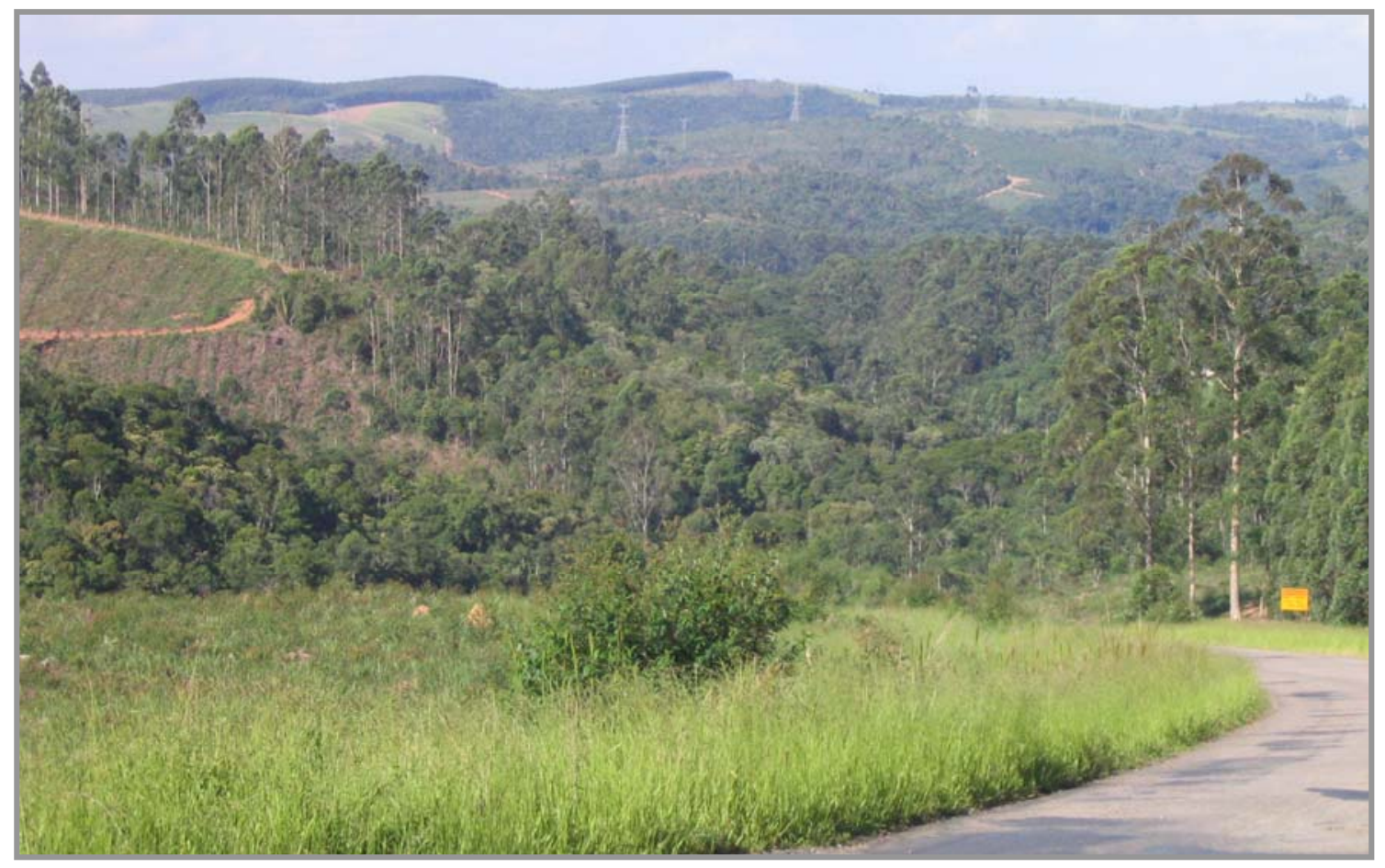

Foto 4: Vista geral da região Sul do Município, onde predomina a silvicultura com "eucaliptus" e remanescentes de Mata Atlântica.

As tradicionais técnicas agrícolas (derrubadas, queimadas e roçadas) são as responsáveis pela devastação florestal intensa. Uma das conseqüências dessas práticas é o aparecimento de diversas associações vegetais secundárias de capoeira, sapezal, samambaial, campo sujo, pastagem, campo antrópico e de áreas degradadas a tal ponto que a vegetação não tem mais condições de se regenerar, especialmente quando a presença de determinado fator erosivo atua no processo de degradação. 
A Mata Atlântica (Floresta Ombrófila) possui árvores de até 30 metros de altura, encontrando-se exemplos de virola, jequitibá, cedro, maçaranduba e pioneira, entre outras. Outros dois estratos arbóreos são encontrados com árvores de 5 a 10 metros de altura e entre 15 e 20 metros. Entre estas árvores, encontram-se epífitas, bromélias, orquídeas, cactus, antúrios e outras espécies vegetais.

A grande área ao Sul do Município, ocupada pela Mata Atlântica, tem um grande valor hidrológico e guarda a condição de banco genético de natureza tropical. Dotado de ecossistemas representativos em termos de fauna e flora, é capaz de funcionar como espaço serrano regulador para a manutenção das qualidades ambientais e dos recursos hídricos da região litorânea e reverso imediato do Planalto Atlântico Paulista. 


\section{2. - Caracterização Socioeconômica}

Pilar do Sul figura entre os município do Grande Cinturão-Verde de São Paulo, que contribuem para o abastecimento de frutas, legumes e verduras, fornecendo produtos especialmente para o CEAGESP - SP.

Segundo estudos realizados por La Corte (1985), em 1964/65, Pilar do Sul destaca-se como área de fruticultura (caqui, pêssego e laranjas) e de horticulturas (couve-flor, abóbora, batata-doce, cenoura, abobrinha, ervilha, pepino e tomate). La Corte relata que o Município aparece entre os 10 maiores produtores do Estado de São Paulo em ameixa, maçã e uva, cuja produção destina-se, prioritariamente, ao CEAGESP de São Paulo e, secundariamente, ao entreposto da Cantareira. Com relação aos legumes, destacam-se a produção de abóbora, ervilha e tomate.

A Diretoria de Agropecuária e Meio Ambiente de Pilar do Sul realiza, desde o ano de 2001, um extenso trabalho de adequação da legislação municipal para produção e beneficiamento de produtos de origem animal e vegetal. O principal objetivo é resgatar da informalidade os produtores do município e agregar valor aos produtos, estabelecendo normas e critérios para a obtenção dos alimentos, adequando a produção e a comercialização, com certificação da qualidade, de forma a garantir o fornecimento de alimentos saudáveis à população (Diretoria de Agropecuária e Meio Ambiente de Pilar do Sul, 2005).

O Município de Pilar do Sul apresenta uma grande diversidade de exploração agropecuária, com uma nítida setorização do uso da terra, condicionada pelas condições fisiográficas.

As variedades e cultivares recomendadas para a região vão depender do clima, da água, do solo e do manejo a ser empregado no cultivo. O emprego adequado dessas técnicas viabiliza o desenvolvimento do ciclo biológico das plantas, proporcionando ao produtor os ganhos e produtos esperados.

$\mathrm{Na}$ região Sul, de relevo mais acidentado e elevadas altitudes, predomina a silvicultura (Foto 5) e, no restante do Município, intercalam-se áreas de pastagem e de culturas (Foto 6). 


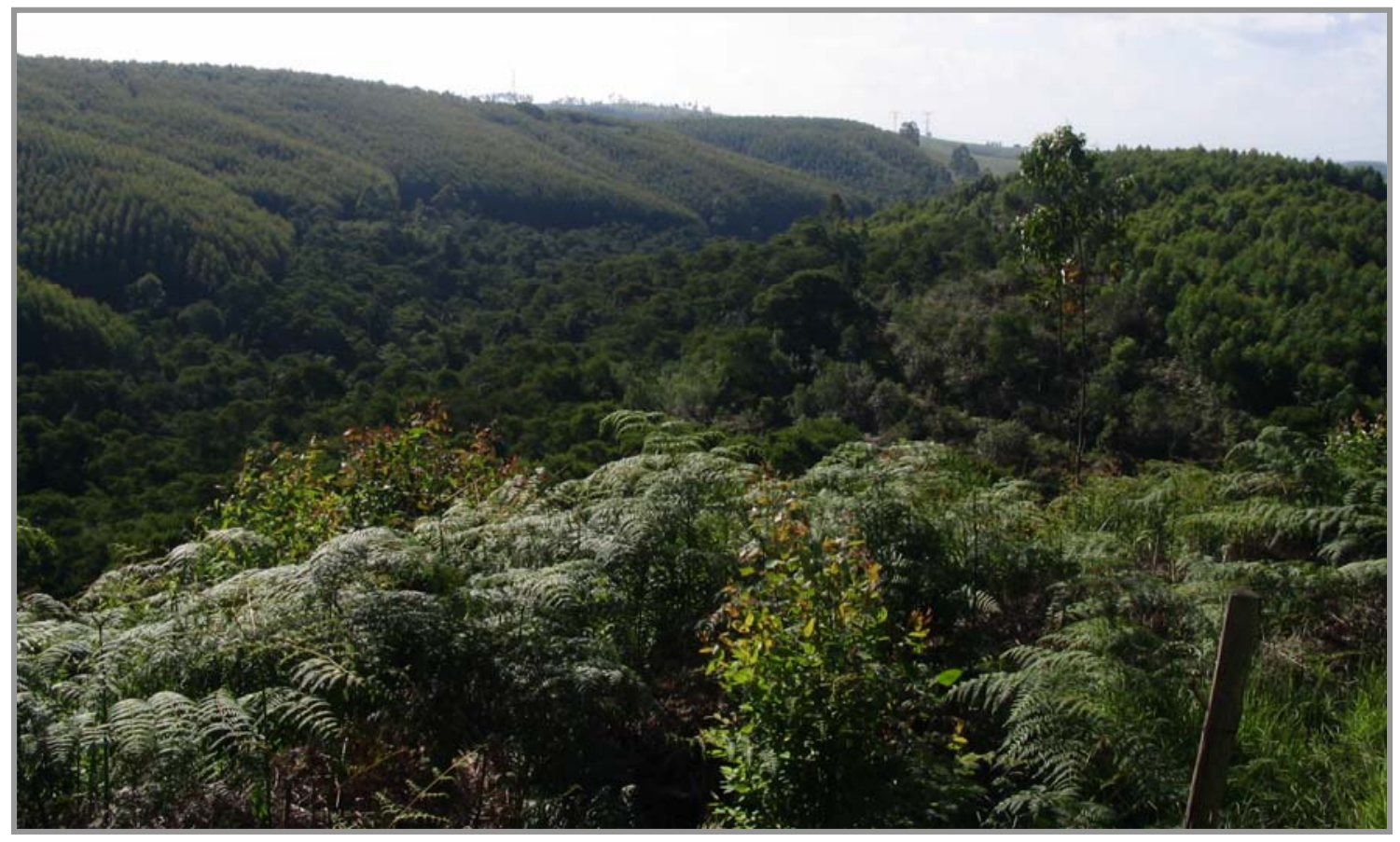

Foto 5: Em primeiro plano do relevo do Planalto Atlântico, o "eucaliptus" em fase de rebrota em terreno recoberto por samambaial. Em segundo plano, área de "eucaliptus" em idade avançada, com Mata Atlântica na parte inferior da vertente.

Foto: Eduardo Reis Rosa, 2005 


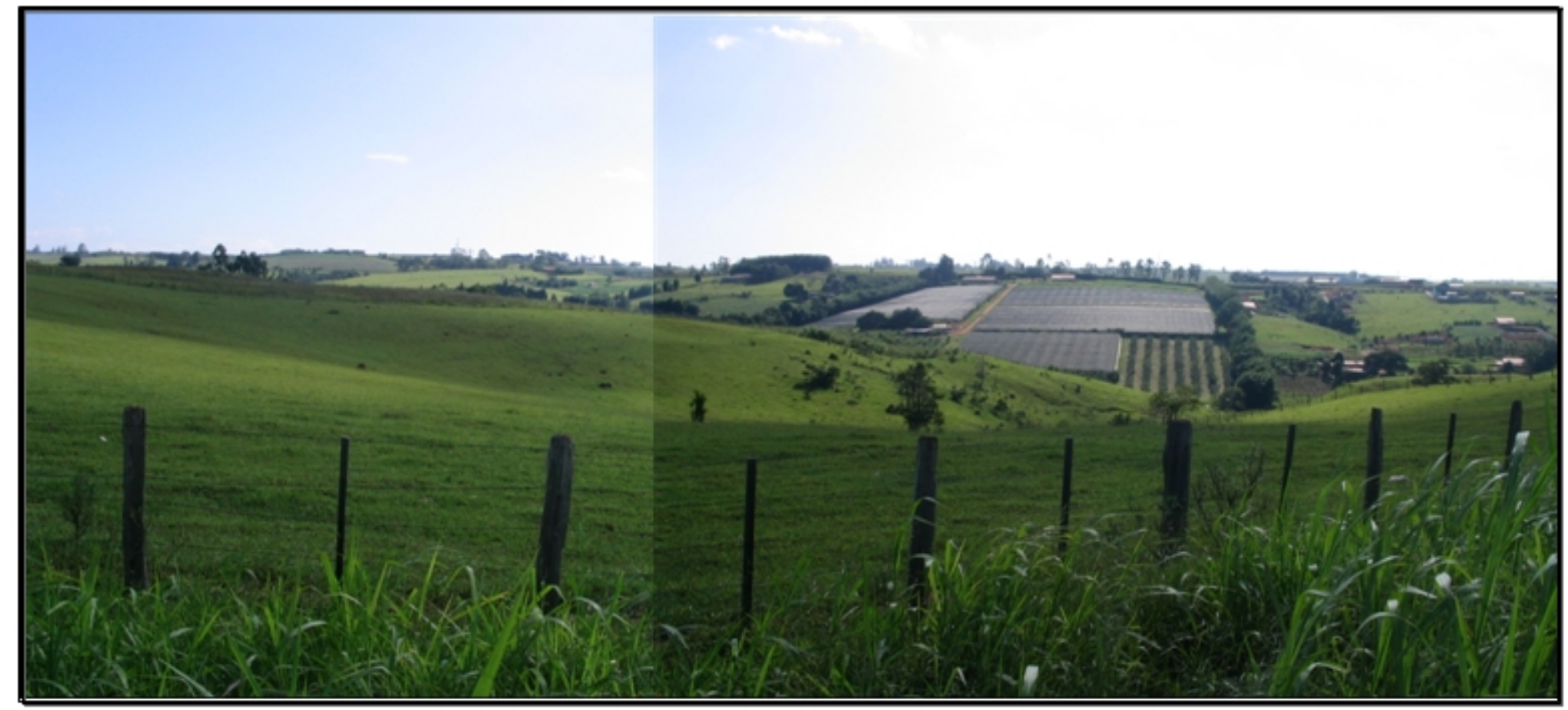

Foto 6: Relevo de colinas suavemente onduladas da Depressão Periférica Paulista. Em segundo plano, área de fruticultura com sombrite para a proteção contra chuva de granizo.

Foto: Eduardo Reis Rosa, 2005 
De acordo com os dados fornecidos pela Casa da Agricultura, conforme levantamento realizado no Município em Novembro/2004 para o Instituto de Economia Agrícola da Coordenadoria de Assistência Técnica Integral (CATI), a agricultura é representada em Pilar do Sul pelas seguintes culturas:

- Culturas anuais 8145 ha
- Fruticultura
- Horticultura

Entre as culturas anuais, o milho, o feijão e a batata são os produtos que se destacam, tanto pela área cultivada como pela produção, conforme pode-se ver nos gráficos apresentados nas Figuras 23 e 24. 
Figura 23 : Área ocupada com Culturas Anuais em Pilar do Sul

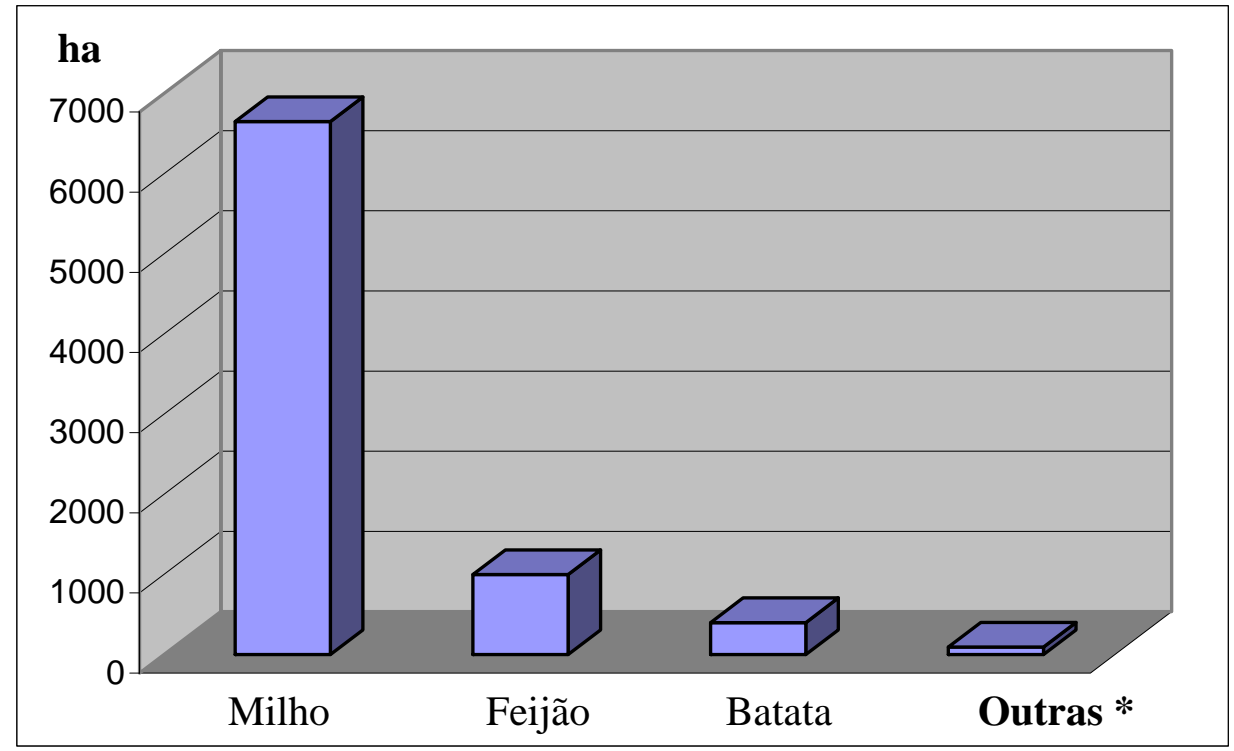

Fonte: Instituto de Economia Agrícola - CATI, 2004

Organização: Eduardo Reis Rosa

Figura 24 : Volume de Produção das Culturas Anuais em Pilar do Sul

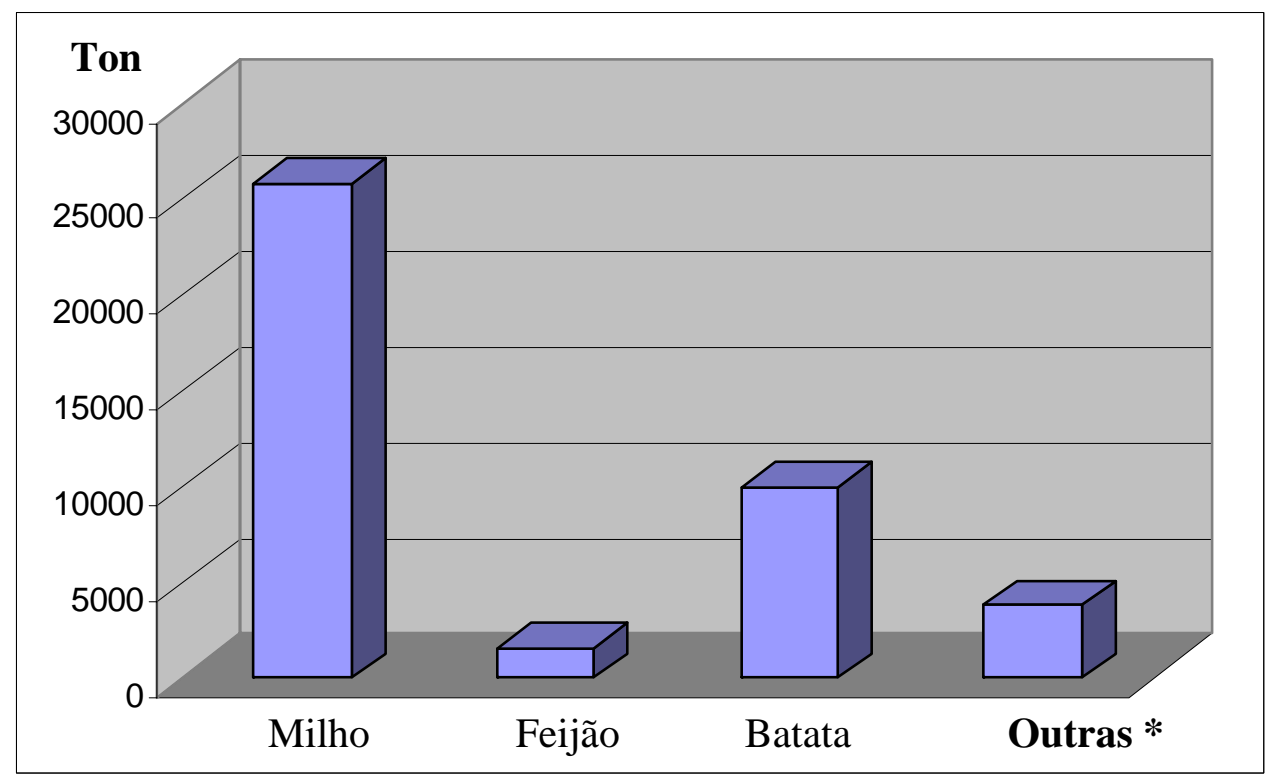

Fonte: Instituto de Economia Agrícola - CATI, 2004

Organização: Eduardo Reis Rosa

* Cana, Arroz, Mandioca e Batata Doce. 
O milho (Foto 7), como principal cultura anual, destina-se basicamente à produção de grãos. Apenas 2,5 \% destina-se à silagem para consumo animal, e 8,5 $\%$, à produção de milho verde.

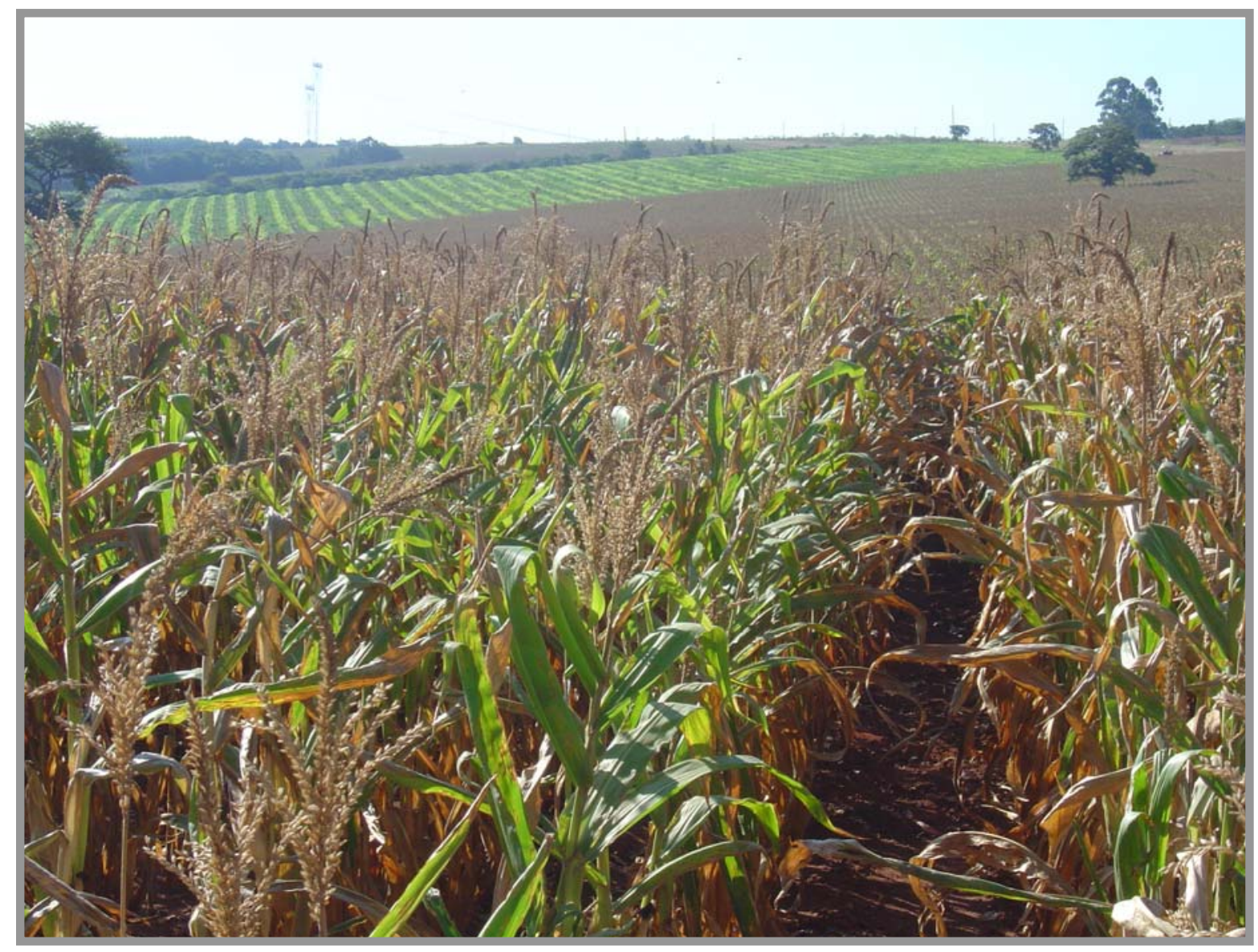

Foto 7 - Área de milho, onde se nota a exposição do solo nas entre linhas.

Com relação ao nível tecnológico das culturas, no geral não se observa grande preocupação com tratos culturais além de calagem e adubação convencionais. As excessões aparecem na região do Pinhal, área centro-oeste do Município, com algumas áreas de agricultura irrigadas pelo método de pivô central (Foto 8), nos quais, normalmente, pratica-se rotação de culturas com milho, feijão, batata ou cenoura, de acordo com a época do ano e com as condições de mercado. 


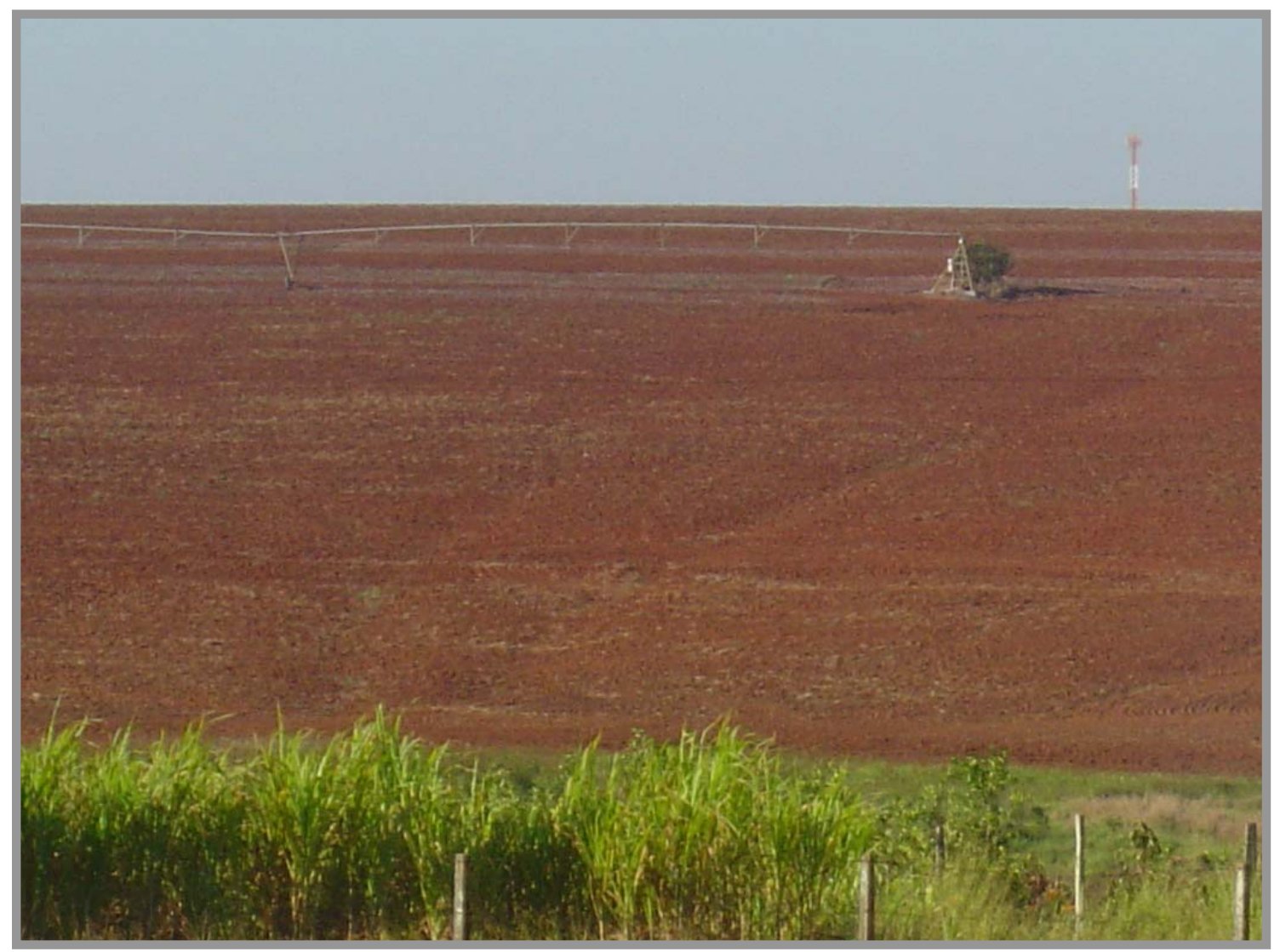

Foto 8 - Área de agricultura anual com sistema de irrigação de Pivô-Central.

Grande parte dos produtores aposta na diversificação das culturas como meio de fugir das condições adversas do mercado e dos aspectos produtivos. A fruticultura é uma das importantes atividades agrícolas de Pilar. Embora não se disponha de dados estatísticos sobre a estrutura da malha fundiária, sabe-se que há uma quantidade significativa de pequenas propriedades (resultado das sucessivas partilhas por herança) o que favorece a exploração da fruticultura e da horticultura.

Entre as frutas mais cultivadas encontram-se a uva (Foto 9), a laranja (Foto 10), a tangerina (poncã e murcote), o maracujá (Foto 11), o caqui (Foto 12), a ameixa, a maçã e a atemóia, além de outras de menor expressão como, a goiaba, a lichia, o limão, a nectarina, a nêspera, a pera, a banana e o pêssego. 
A uva é uma das principais culturas. A produção se destaca nas uvas rústicas de mesa (Niagara Branca e Niagara Rosada) e nas finas de mesa, especialmente a Itália, a Rubi e a Benitaka.

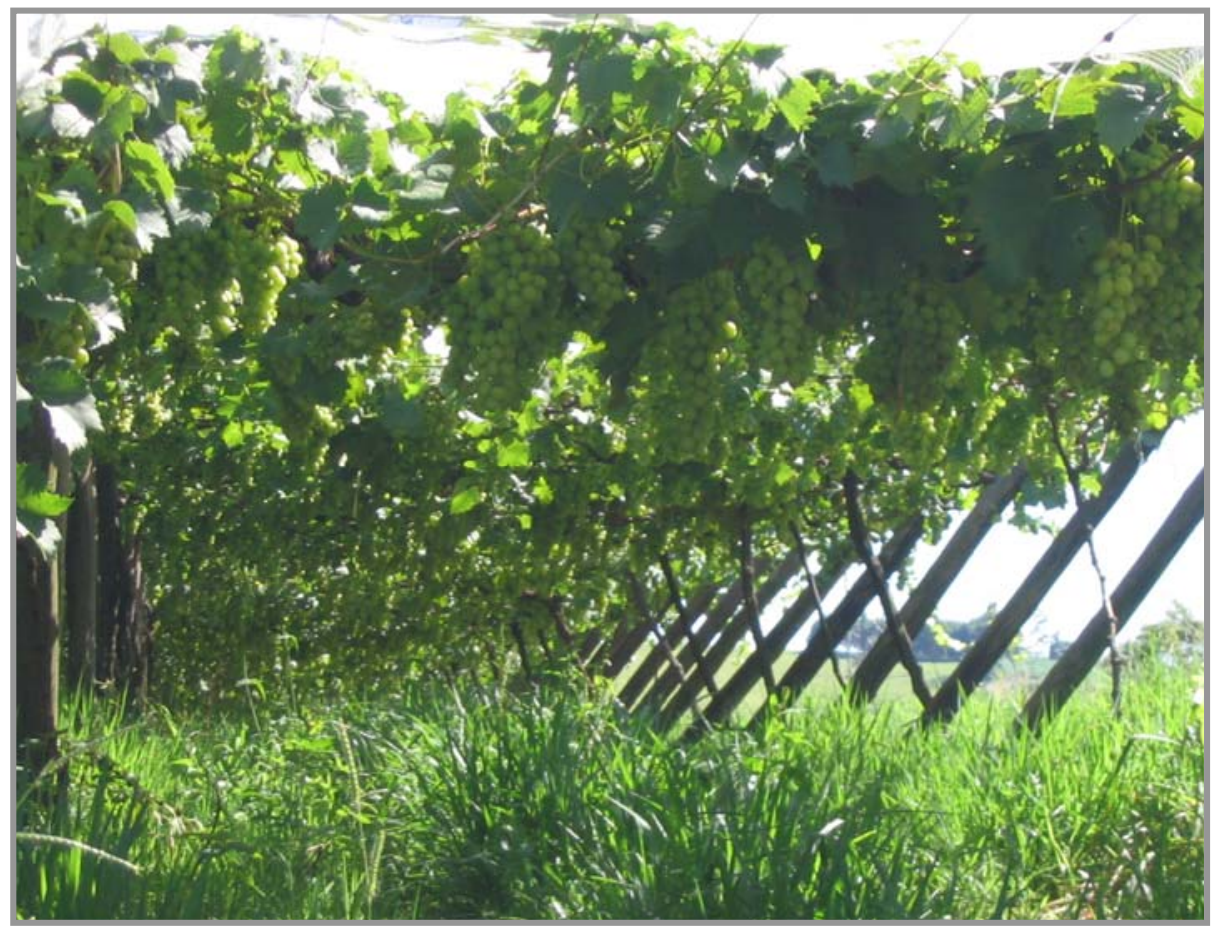

Foto 9: Cultivo de uva Itália em parreiras.

Foto: Eduardo Reis Rosa, 2005

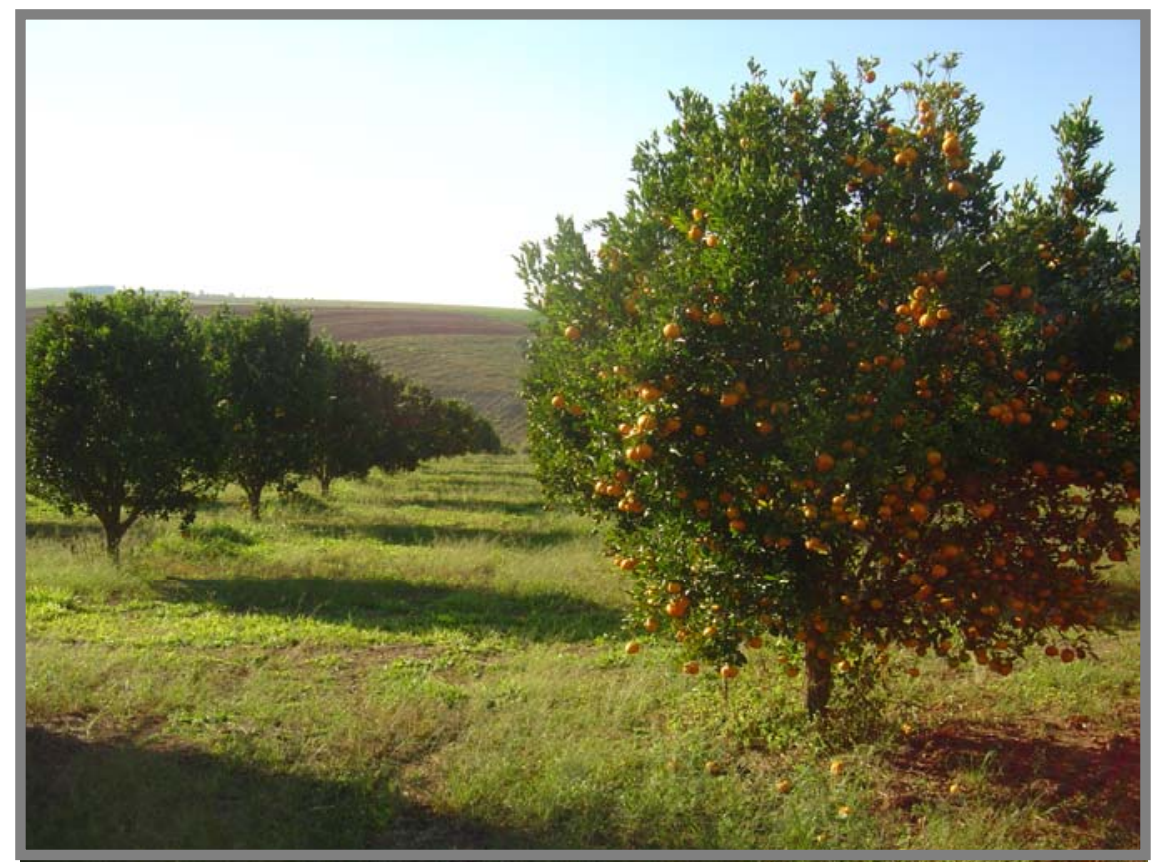

Foto 10: Cultivo de Laranja com solo protegido.

Foto: Eduardo Reis Rosa, 2006 


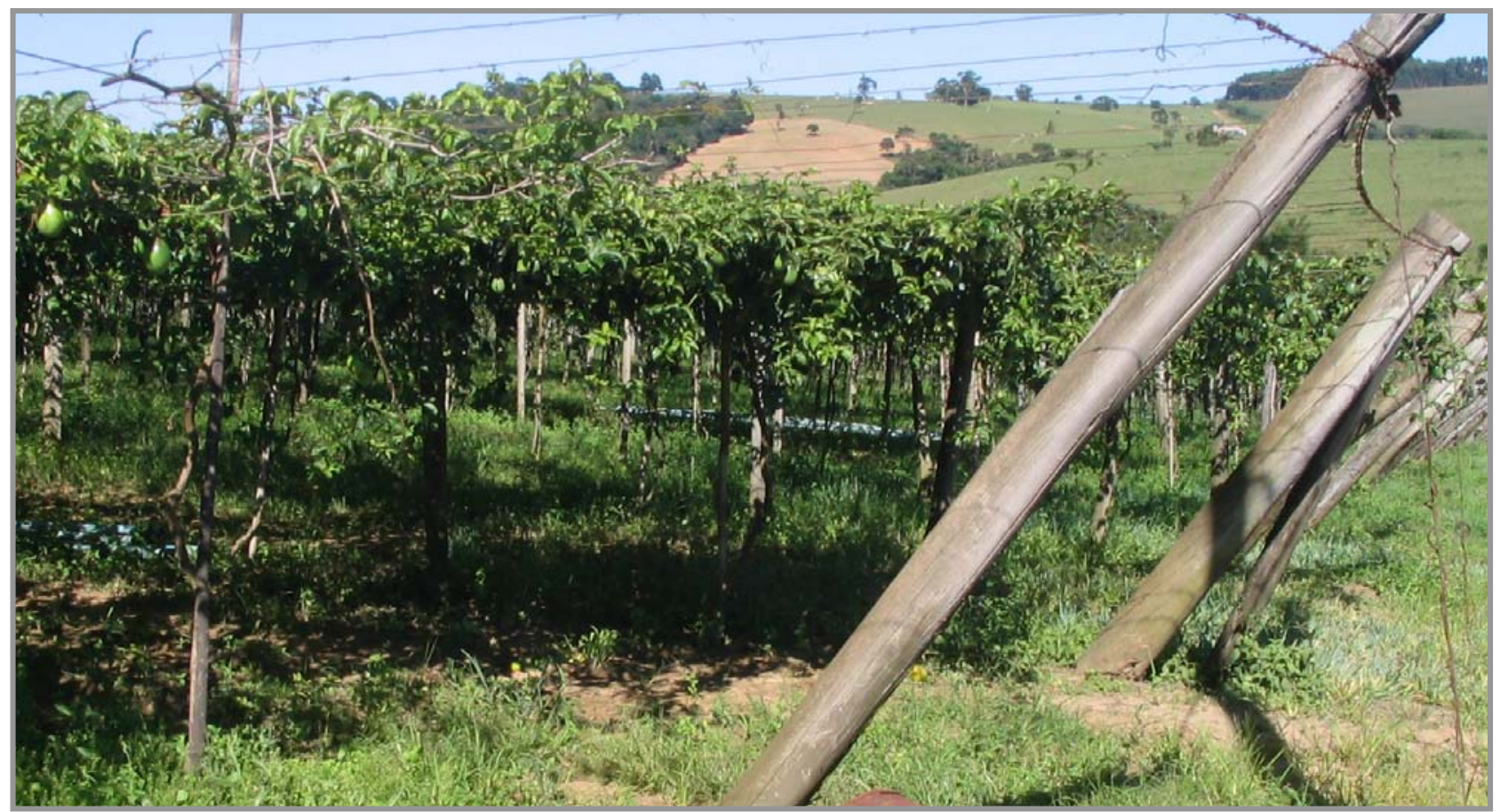

Foto 11: Cultivo do maracujá em parreiras de arame sustentado com mourões de madeira.

Foto: Eduardo Reis Rosa, 2005

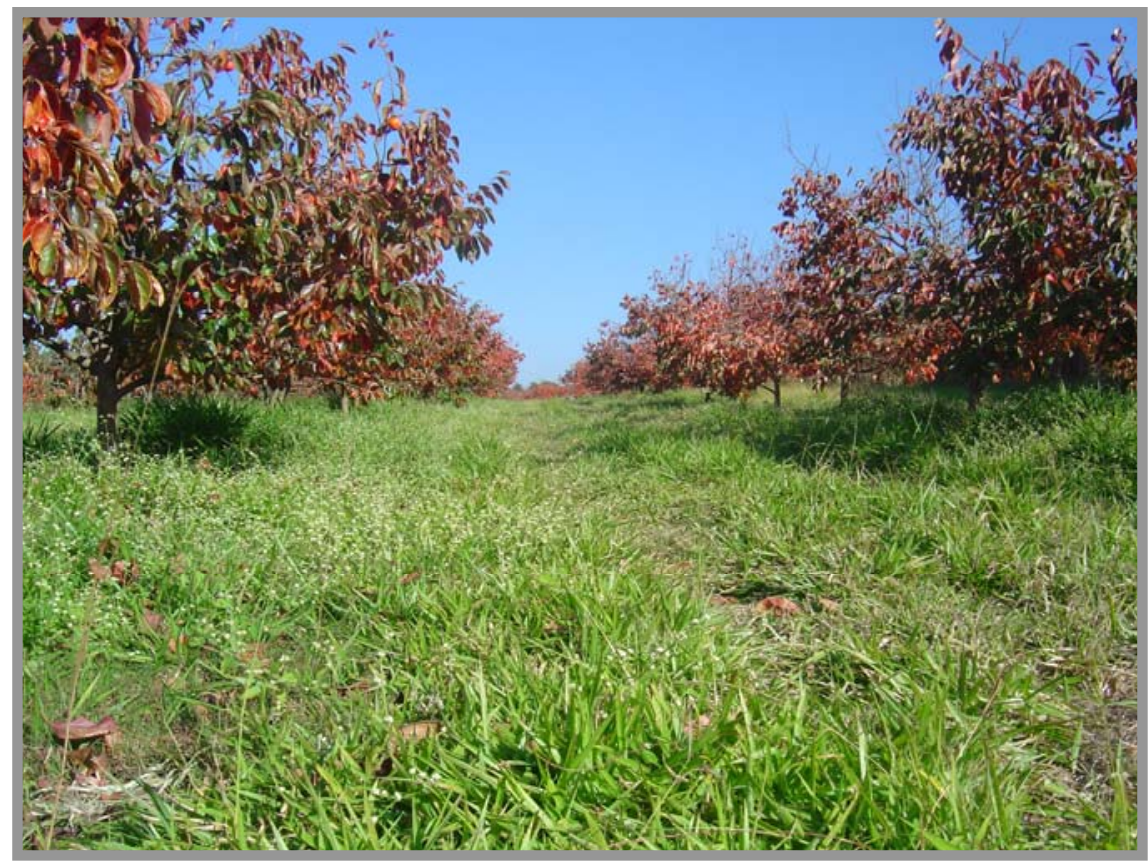

Foto 12 - Cultivo de caqui onde a cobertura vegetal na entre linhas garante a proteção e conservação do solo.

Foto: Eduardo Reis Rosa, 2006 
A fruticultura, podendo proporcionar alta produção em pequenas áreas, tem condições de ser tratada se forma intensiva, mesmo frequentemente utilizando apenas mão-de-obra familiar. Isto possibilita que pequenos proprietários de terras rurais cultivem áreas com diversos produtos, utilizando mão-de-obra externa, quando necessário.

Os cultivos em pequenas áreas permitem o emprego de técnicas especializadas de manejo, com intensivos tratos culturais de poda, calagem, adubação, irrigação, controle de erosão, proteção contra chuvas de granizo e cultivos protegidos, caracterizando um bom nível tecnológico. Exemplificas a seguir com as Fotos 13, 14 e 15. (Fotos: Eduardo Reis Rosa, 2006)

Foto 13
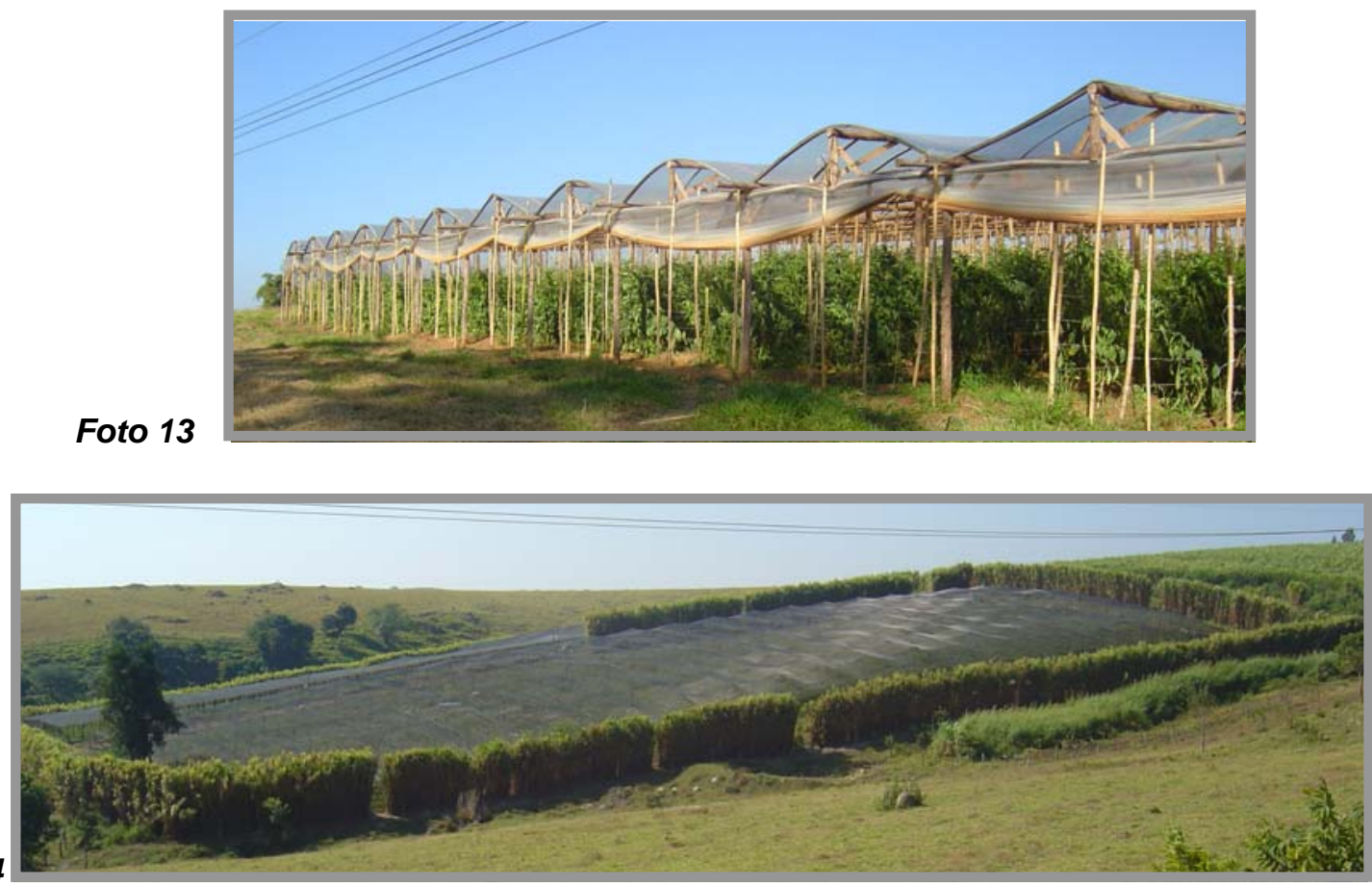

Foto14

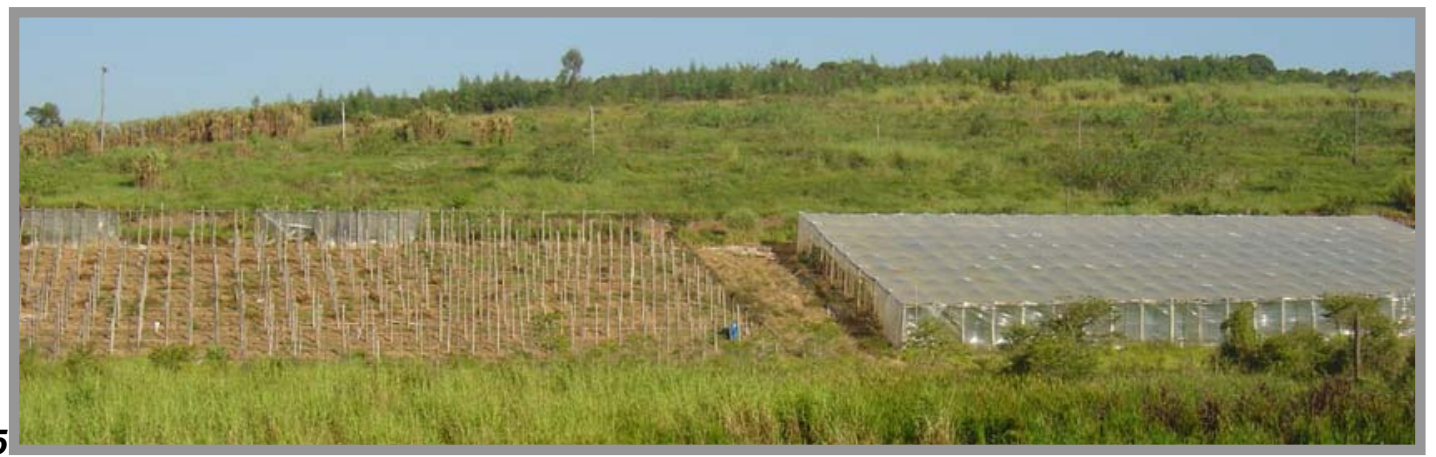

Foto 15 
As Figuras 25 e 26 representam a área e a produção, respectivamente, das principais frutas cultivadas.

Figura 25 : Área Cultivada com Fruticultura em Pilar do Sul

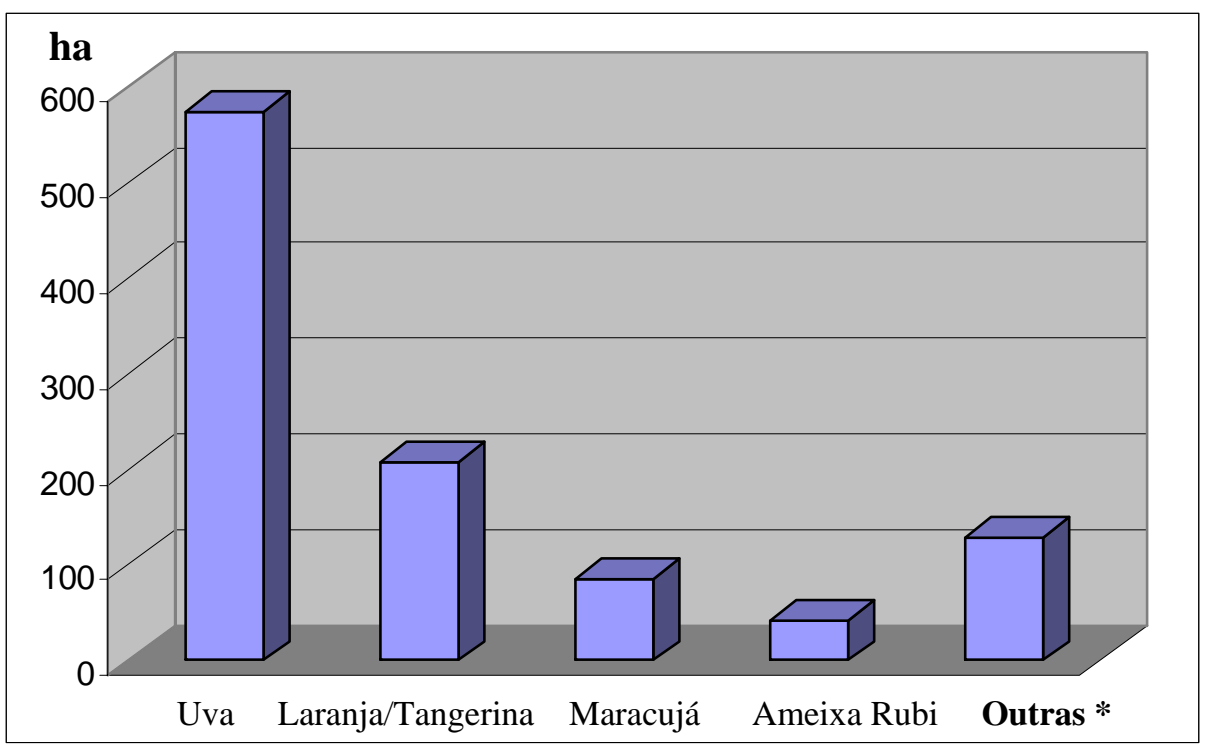

Figura 26: Volume de Produção da Fruticultura em Pilar do Sul

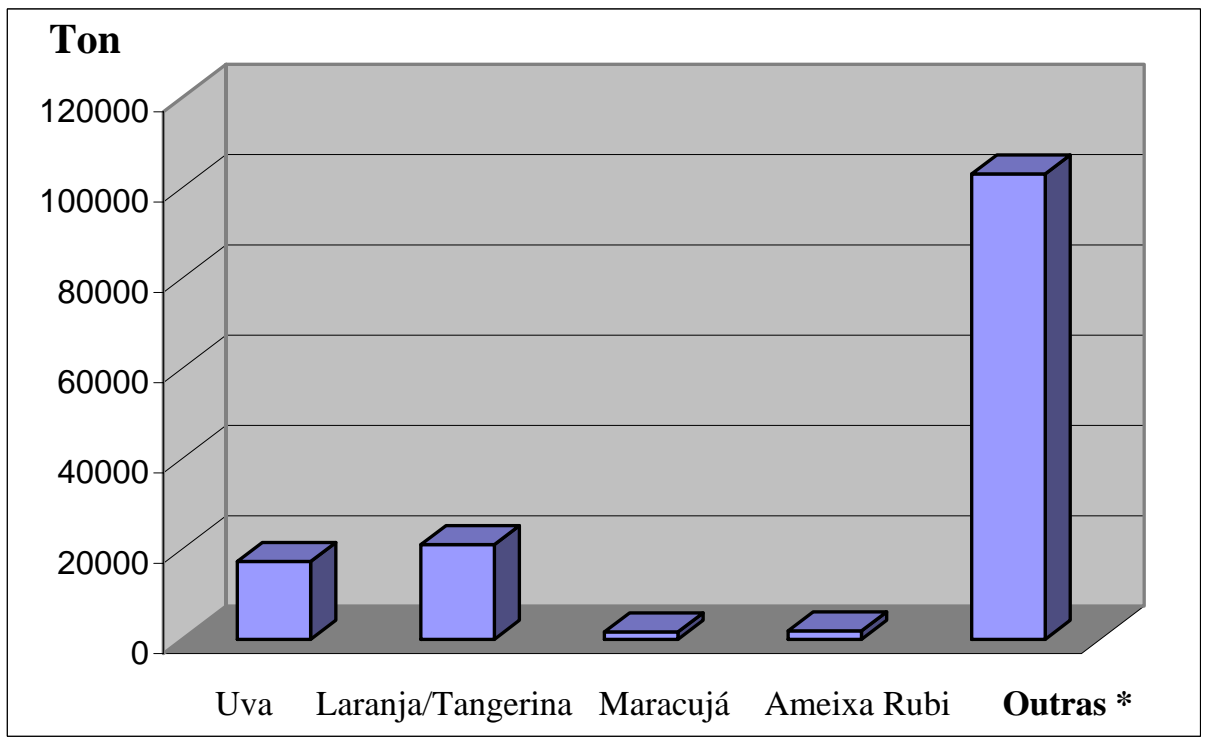

- Caqui, Atemóia, Maçã, Goiaba, Lichia, Limão, Nectarina, Nêspera, Pera, Banana, Pêssego e Palmito.

(Fonte: Instituto de Economia Agrícola - CATI - 2004 / Organização: Eduardo Reis Rosa) 
Situação semelhante à fruticultura ocorre em relação à horticultura (Foto 16). Os legumes e hortaliças ainda oferecem a vantagem de um ciclo vegetativo mais curto, possibilitando maior diversificação e rotação de culturas. Entre os produtos mais cultivados estão a cenoura, o repolho, a cebola, a beterraba e outros (abóbora, abobrinha, couve-flor, ervilha torta, pepino, pimentão, vagem, tomate, alface e beringela), ocupando um total de 800 ha.

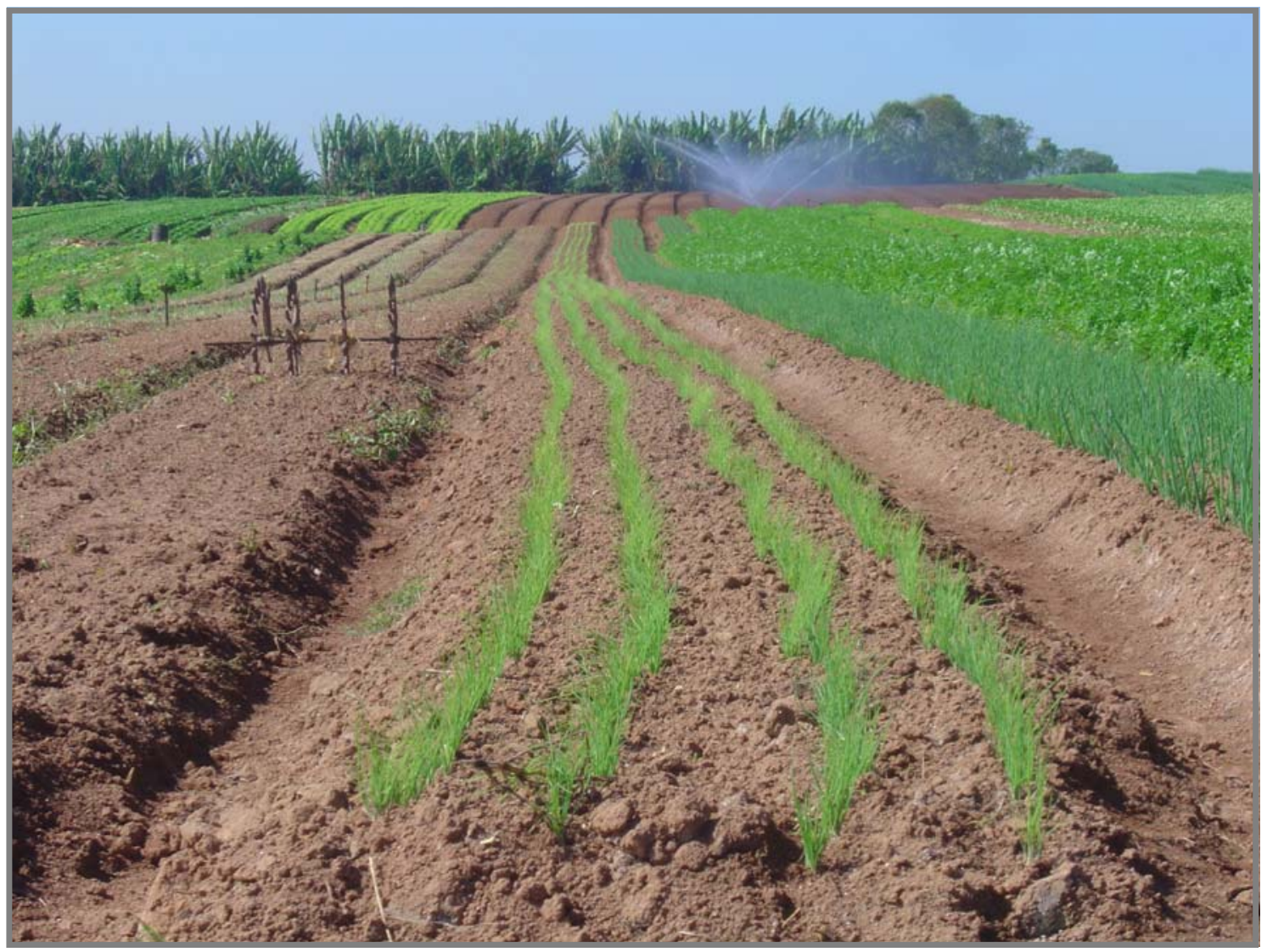

Foto 16 - Horticultura e prática de irrigação por aspersão.

Foto: Eduardo Reis Rosa, 2006

As Figuras 27 e 28 mostram as áreas cultivadas e o volume de produção da horticultura em Pilar do Sul. 
Figura 27: Área de Horticultura em Pilar do Sul

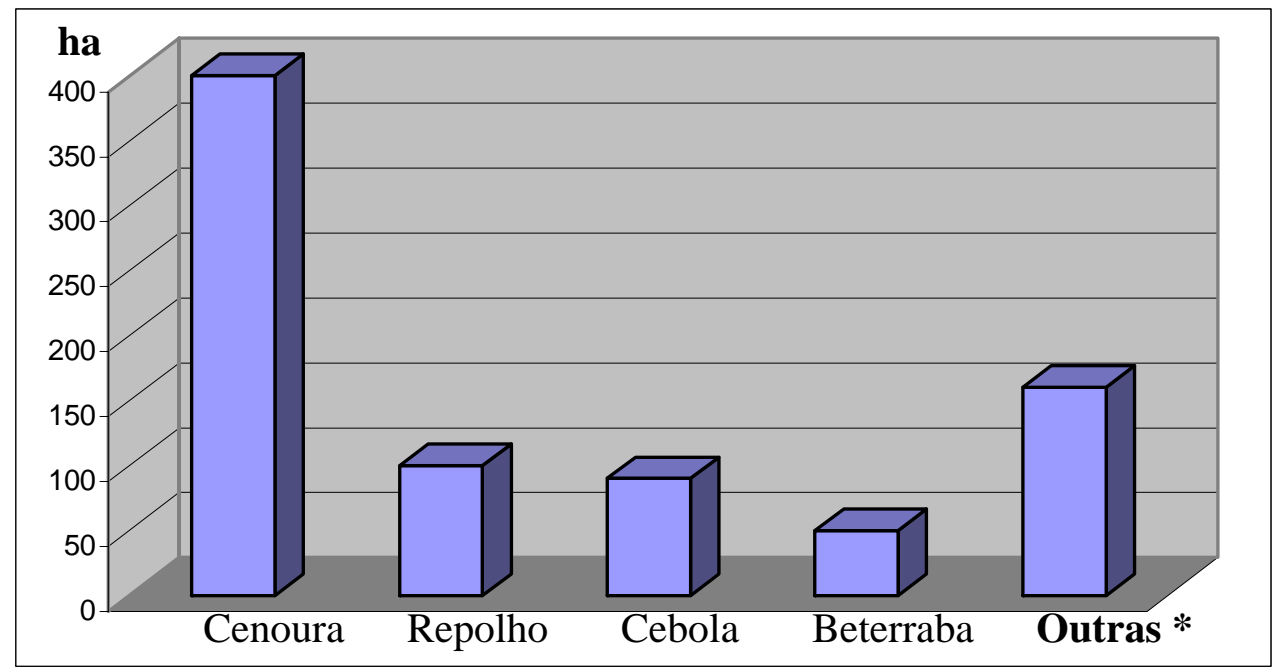

Fonte: Instituto de Economia Agrícola - CATI, 2004

Organização: Eduardo Reis Rosa

Figura 28: Volume de Produção de Horticultura em Pilar do Sul

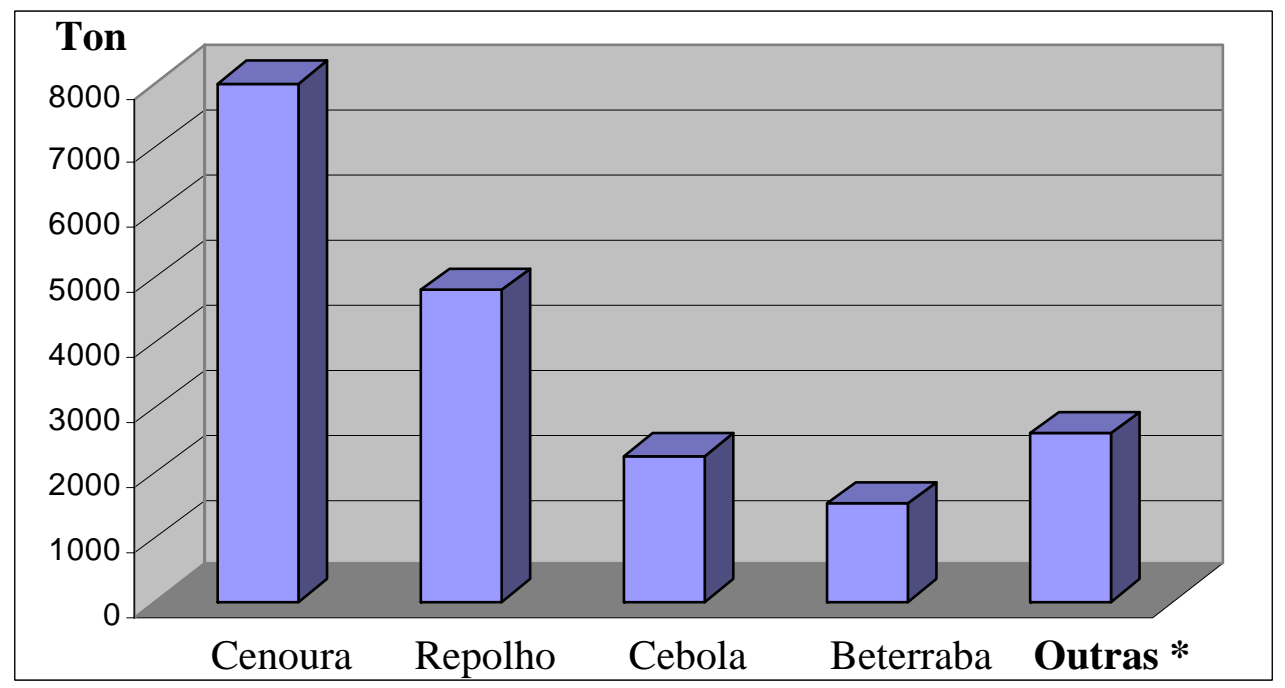

Fonte: Instituto de Economia Agrícola - CATI, 2004

Organização: Eduardo Reis Rosa

* Abobrinha, Abóbora Seca, Tomate, Pepino, Couve-Flor, Pimentão, Ervilha Torta, Vagem, Berinjela e Alface. 
A atividade pecuária em Pilar do Sul, embora presente, não é tão importante como em outras regiões do Estado. De acordo com dados fornecidos pela Casa da Agricultura (2004), conta com rebanho bovino de 22000 cabeças, sendo 10000 destinados ao corte, 2000 para produção de leite e 10000, misto. Em 2004, foram abatidas 3600 cabeças de gado e produzidos cerca de 2.173.000 litros de leite, dos quais 55\% de leite B e $45 \%$ de leite C. Este fato demonstra que grande parte dos produtores de leite apresenta um bom nível tecnológico no manejo do rebanho. As pastagens, em geral, encontram-se em bom estado de formação, oferencendo boa proteção ao solo (Foto 17).

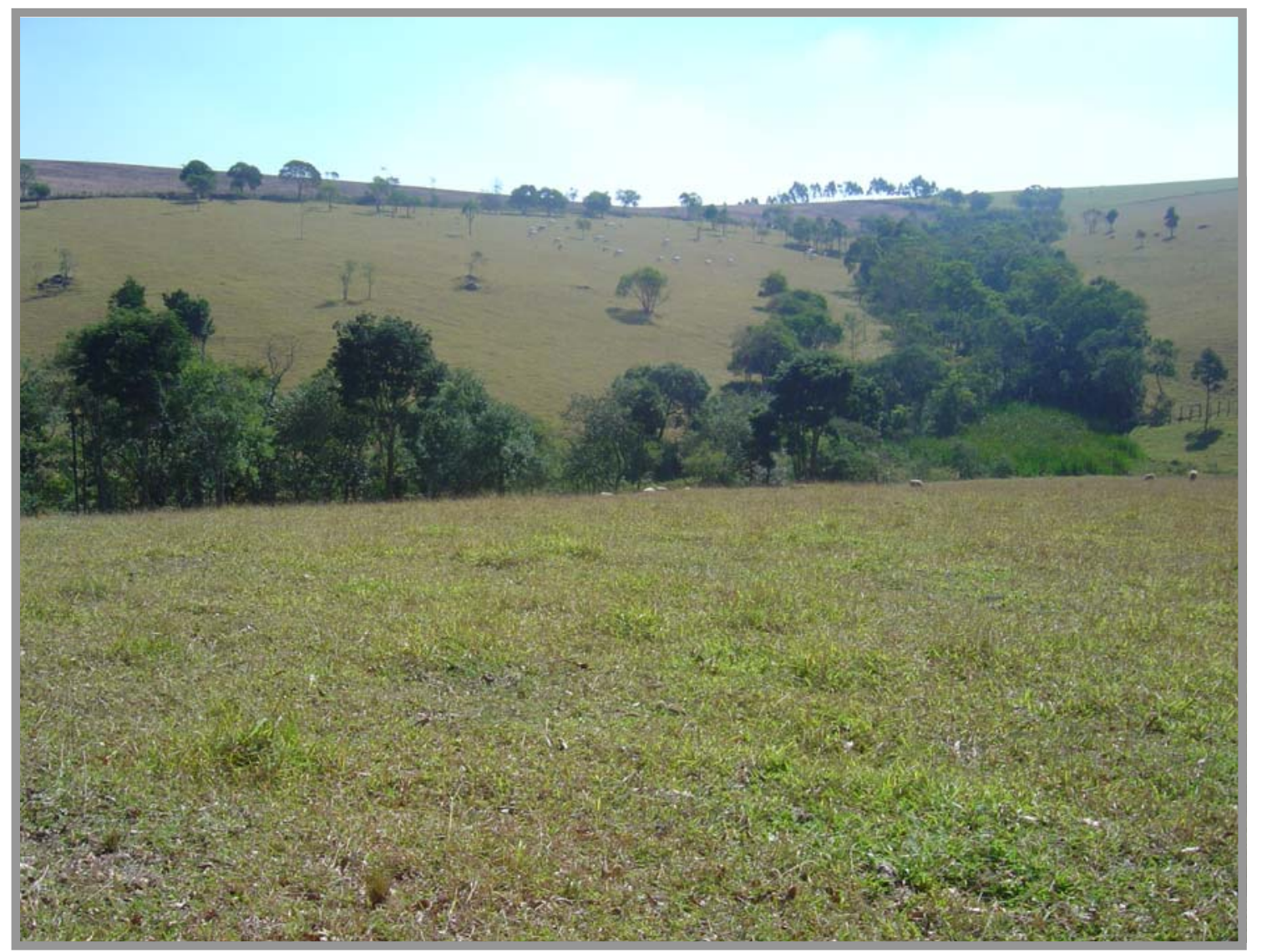

Foto 17 - Pastagem extensiva em bom estado de conservação oferecendo boa proteção ao solo. 
Em áreas mais ingremes, identificam-se pastagens com curvas de nível (Foto 18).

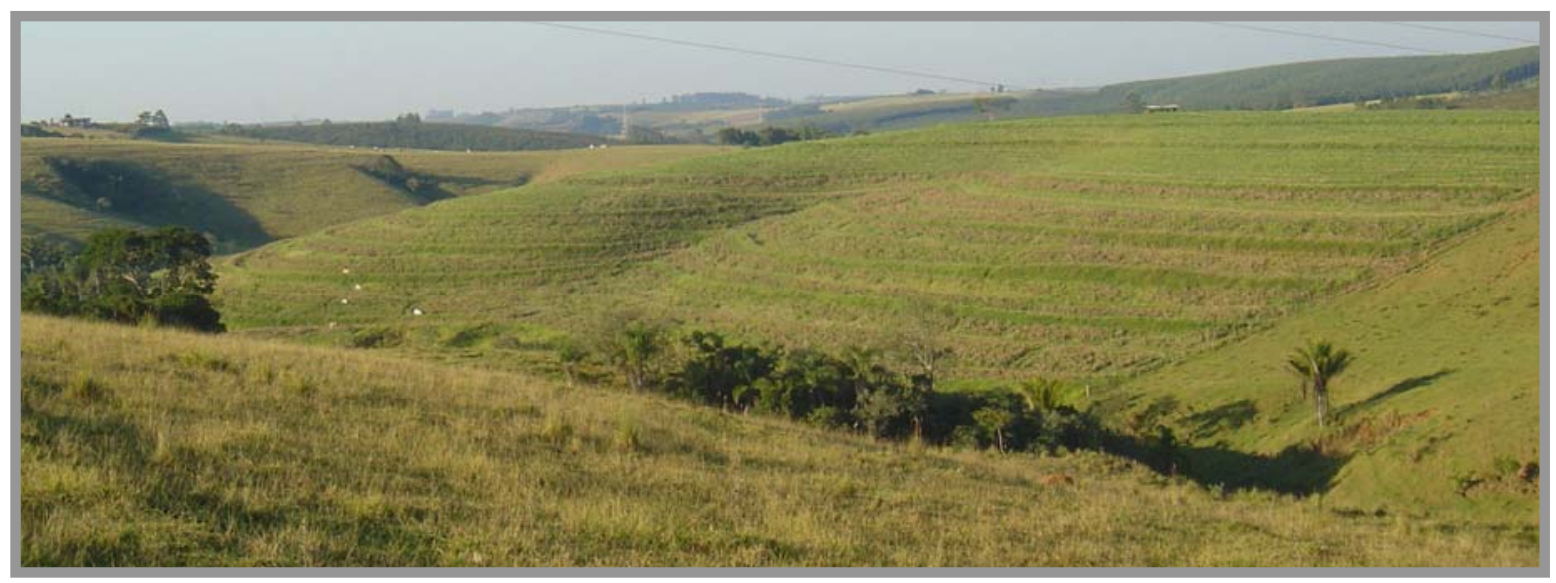

Foto 18 - Pastagem com curvas de nível

Foto: Eduardo Reis Rosa, 2006

Existem ainda, casos de pastagem degradada em áreas ingremes ou onde o pastoreio é muito intenso (Foto 19).

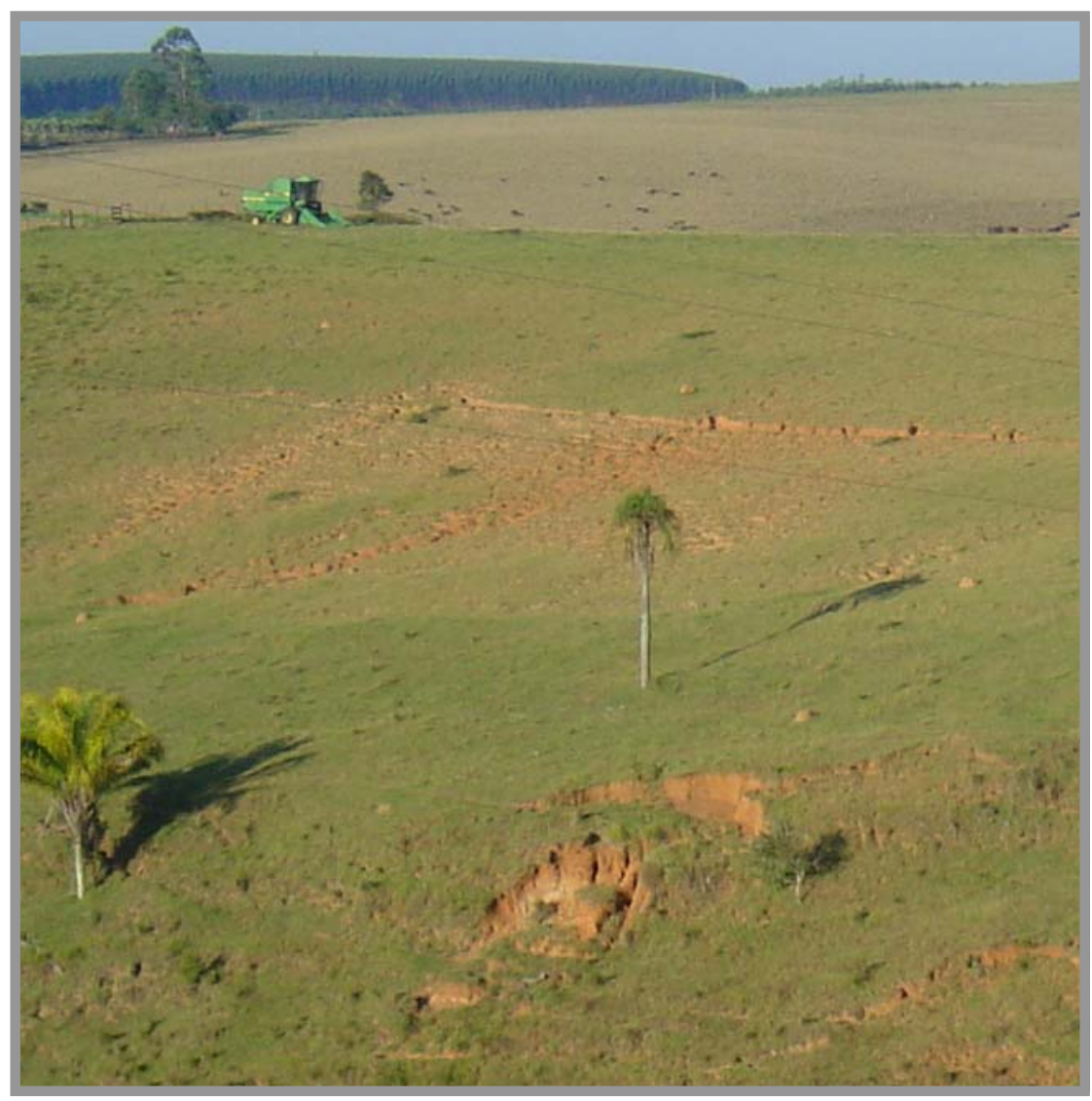

Foto 19 - Pastagem degradada, apresentando processos erosivos. Foto: Eduardo Reis Rosa, 2006 
Os dados levantados pela Casa da Agricultura registram, ainda, a existência de 2000 bubalinos para a produção de leite, 2000 suínos, 1500 equinos e muares e 60000 galinhas que produzem cerca de 1.800 .000 dúzias de ovos/ano. Finalmente, a apicultura é uma atividade relativamente importante no Município, que conta com 51 apicultores cadastrados, que criam cerca de 600 colméias, produzindo 1.800 kg de mel/ano e $1.800 \mathrm{~kg}$ de cera.

Uma importante atividade agrícola é a silvicultura, que domina quase toda a área do Planalto Atlântico ao Sul e Sudeste do Município. Segundo informações não oficiais, a Companhia Suzano de Papéis é proprietária de cerca de 25\% das terras localizadas nessa região, e as utiliza para cultivo do "eucaliptus" predominatemente da espécie "grandis", adaptada a regiões de clima temperado e áreas com a ocorrência de geadas frequentes (GALETI - 1989).

A Foto 20 mostra a situação de solo relativamente desprotegido em área de silvicultura em fase inicial.

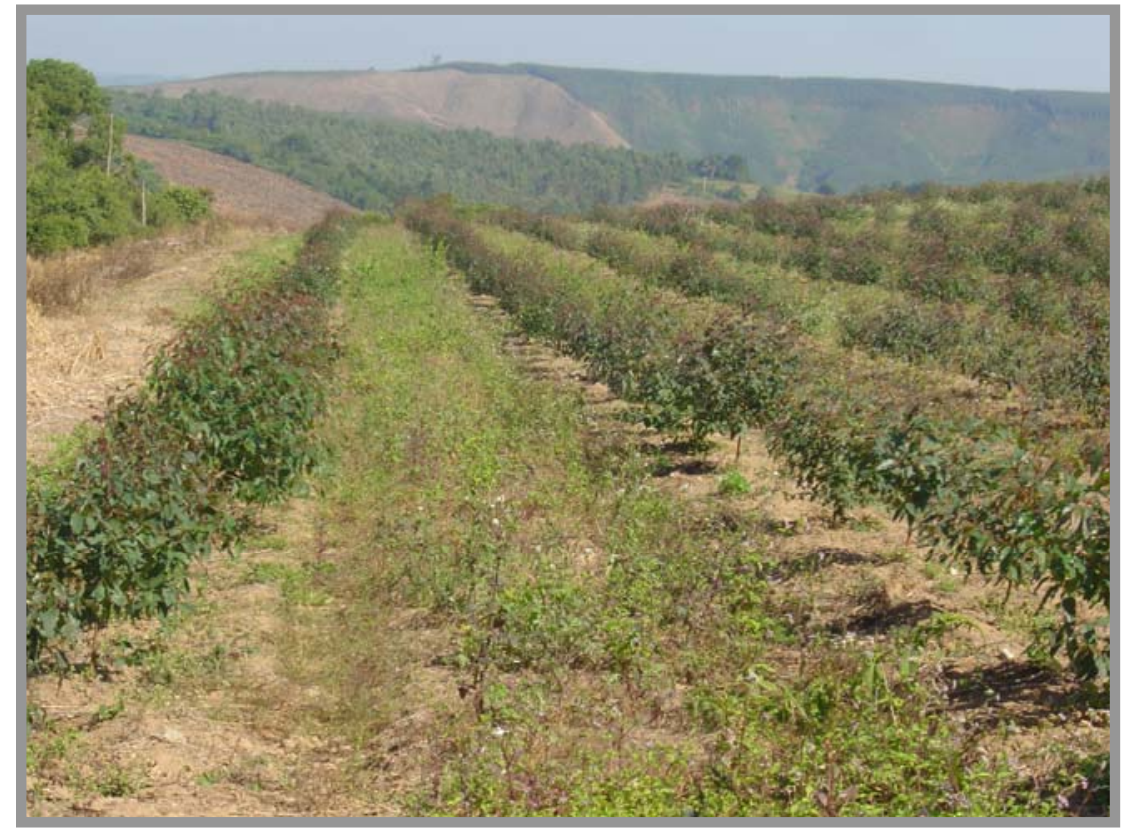

Foto 20 - Eucalipto em fase inicial

Foto: Eduardo Reis Rosa, 2006 
A Foto 21 mostra o solo com boa proteção em área de silvicultura em fase mais avançada de desenvolvimento. Tal situação oferece boa proteção à ocorrência de processos erosivos.

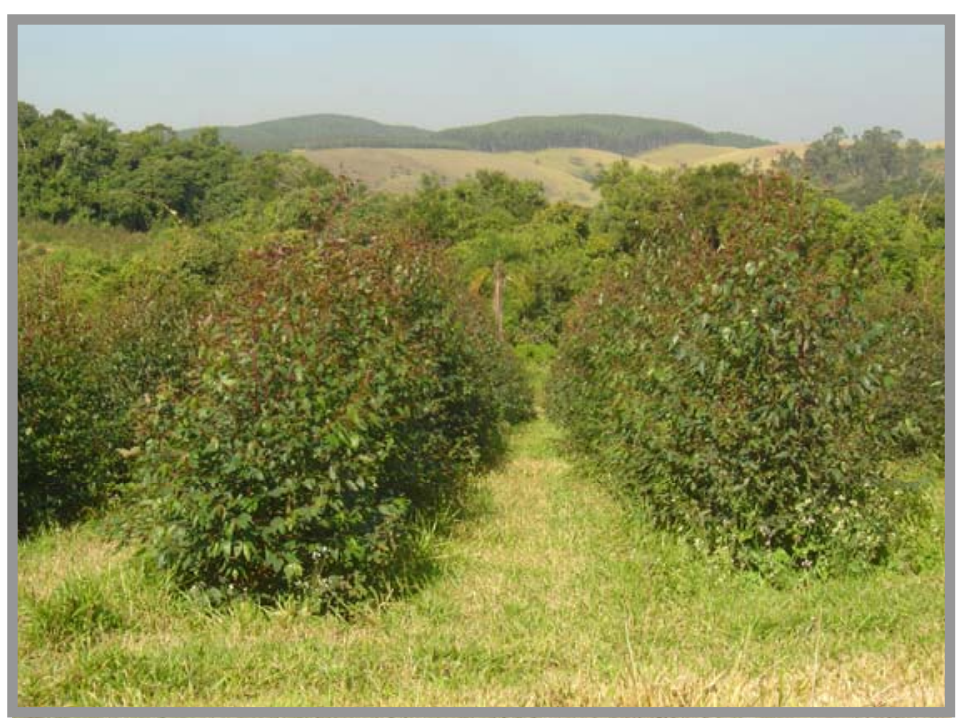

Foto 21 - Eucalipto em fase mais avançada e com boa proteção do solo.

O primeiro corte dos "eucaliptus" ocorre, nomalmente após os 6 anos de idade. Quase toda a produção destina-se ao fornecimento de celulose às fábricas de papel Suzano e Votorantim (Jacareí). A Foto 22 mostra área de silvicultura recém cortada.

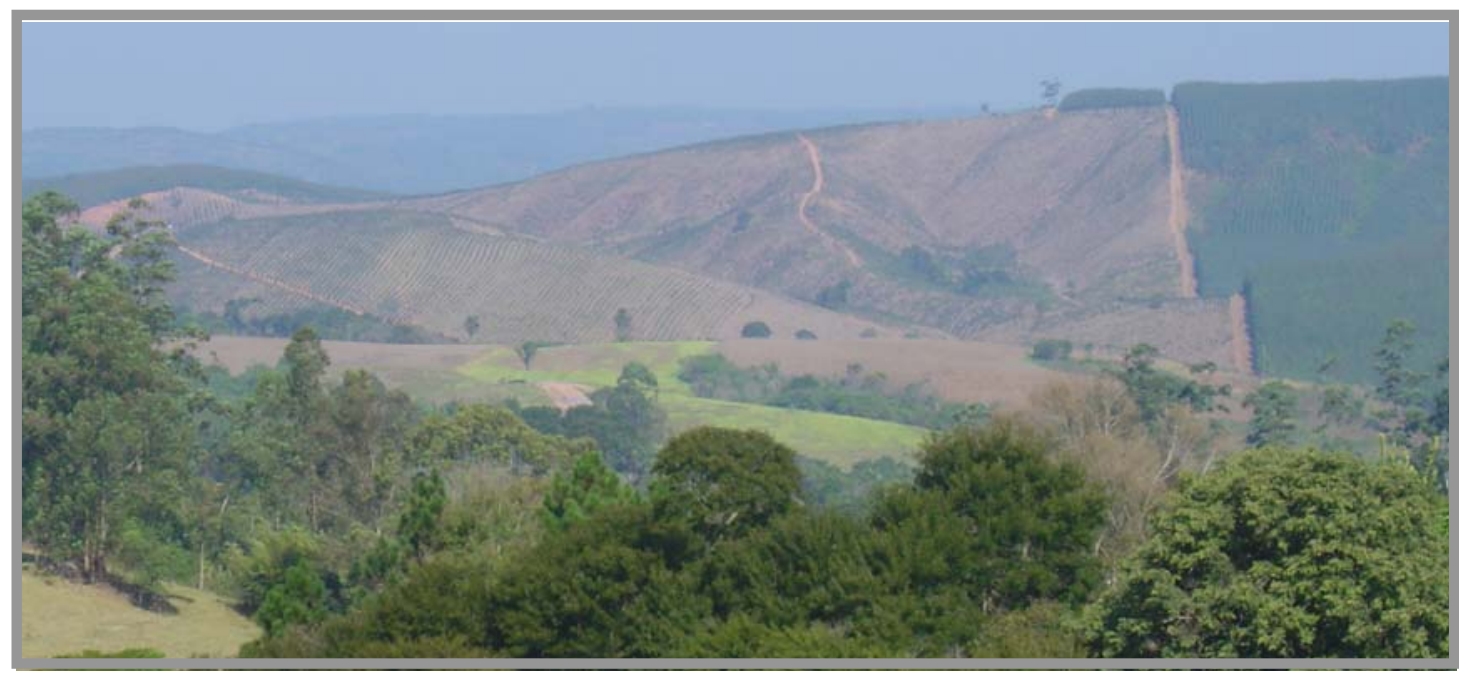

Foto 22 - Área de Eucalipto recém cortado, expondo o solo e tornando-o altamente suscetível à ocorrência de processos erosivos.

Fotos: Eduardo Reis Rosa, 2006 
O Mapa de Uso e Cobertura da Terra (Figura 30), a partir das fotografias aéreas de 2000, e com auxílio das imagens LANDSAT de 1995 e de 2000, mostra que a atividade de silvicultura encontra-se em expansão, não só em continuidade à grande área localizada ao sul do Município, como por meio do acréscimo de manchas disseminadas pelas áreas agrícolas e de pastagem nas demais regiões. Segundo informações de proprietários locais, isso se deve ao alto rendimento que a silvicultura oferece. O primeiro corte aos 6 anos, proporciona recursos superiores ao valor da própria terra. A Figura 29 mostra a imagem de satélite e a fotografia aérea, base para a interpretação das diferentes classes de Uso e Cobertura da Terra.

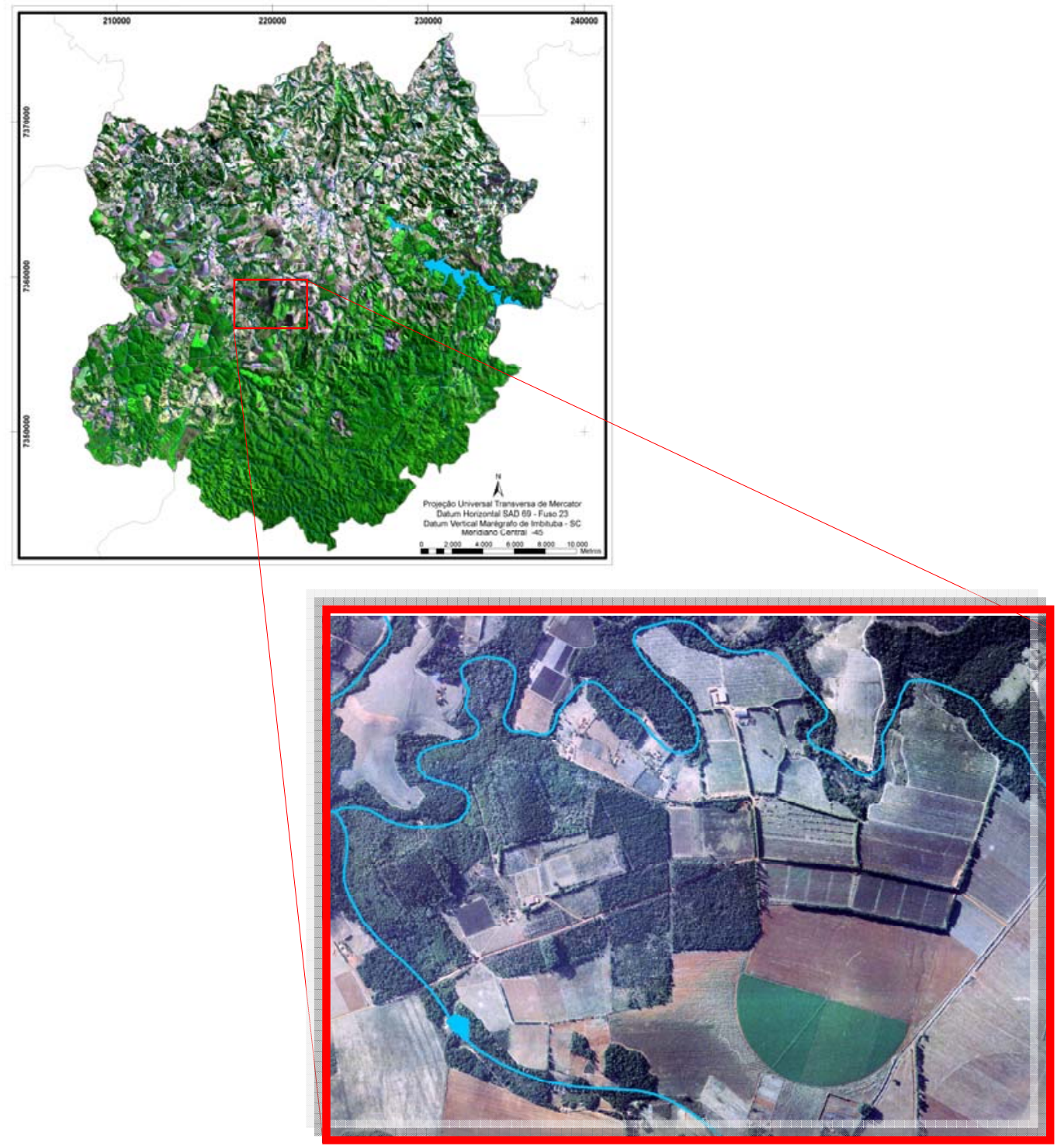

Figura 29 - Imagem de satélite e fotografia aérea mostrando o uso da terra. 


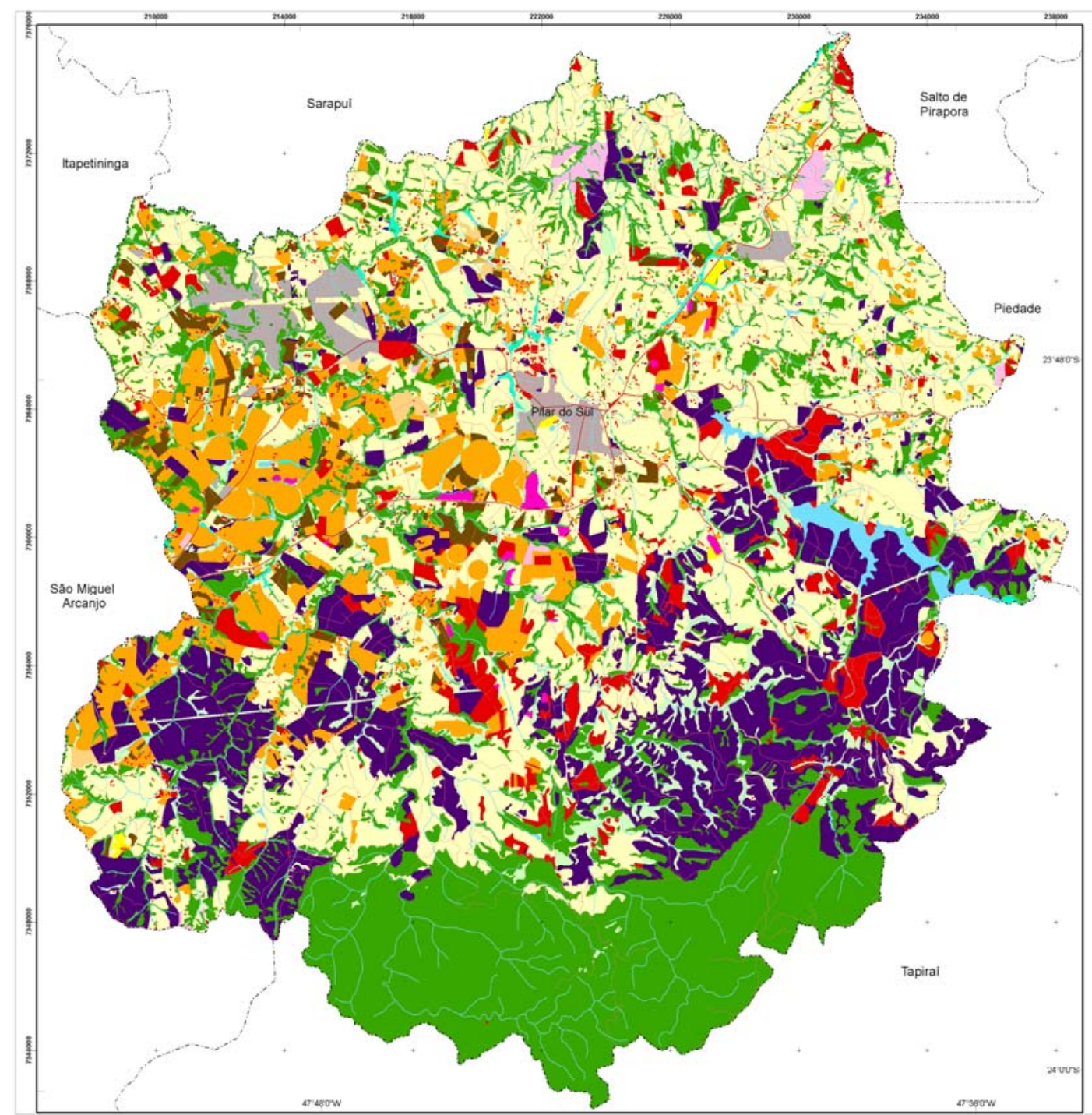

Figura 30

Mapa de Uso e Cobertura da Terra
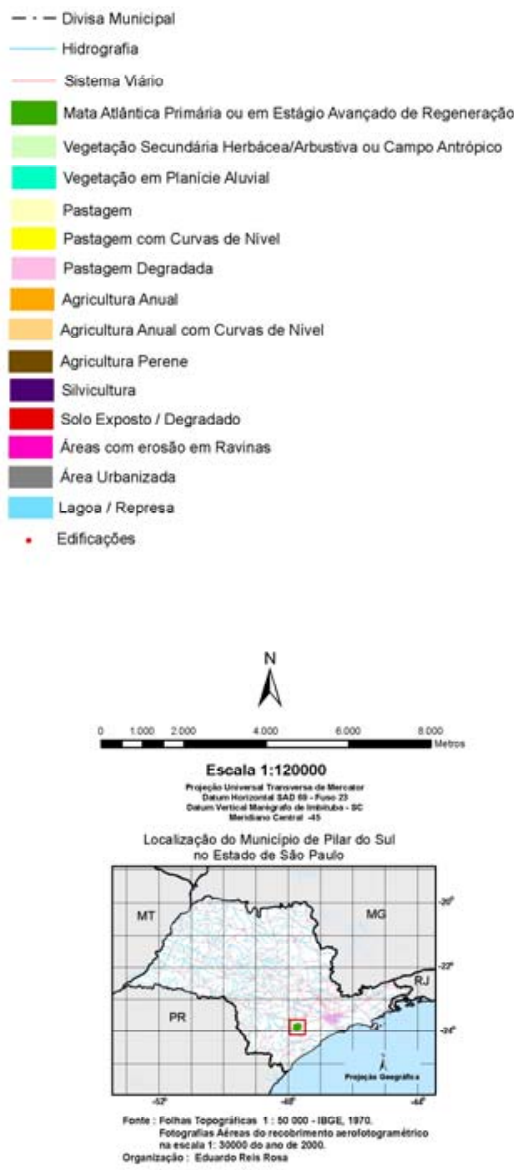


\section{5 - Potencial de Degradação Ambiental}

$\mathrm{Na}$ análise dos fatores que influenciam e potencializam os processos erosivos, é fundamental a abordagem regional de clima, hidrologia, geologia, pedologia, topografia, vegetação e aspectos do manejo e da sócio-economia.

O manejo inadequado dos solos, geralmente elimina sua cobertura vegetal, torna-os compactados e altera suas propriedades, resultando em menor capacidade de infiltração e maior escoamento superficial, intensificando os processos erosivos.

Especialmente nos processos lineares, é necessário o conhecimento do comportamento hídrico ao longo da vertente e a distribuição espacial dos horizontes pedológicos e sua relação com feições do relevo. Esta abordagem metodológica iniciada por Bocquier (1973) e desenvolvida por Boulet (1978), conhecida como "Análise Estrutural da Cobertura Pedológica", contempla não somente a diferenciação vertical dos horizontes do solo, mas também a diferenciação lateral ao longo da vertente. Esta abordagem leva ao conhecimento de aspectos de morfogênese e pedogênese, além de permitir compreender a dinâmica das águas superficiais e subsuperficiais ao longo das vertentes e setorização em áreas relativamente homogêneas quanto à susceptibilidade aos processos erosivos (Queiroz Neto, J. P. - 1993).

Em função das características do meio físico os processos de degradação podem ser intensificados com ou sem a intervenção humana. Os tipos de solos e suas descontinuidades litológicas e pedológicas, assim como o contato solo-rocha abrupto e encostas íngremes são exemplos de fatores naturais que contribuem para desencadear a ocorrências dos processos erosivos e degradantes.

Os critérios sociais determinam os diversos tipos de uso, que podem ser degradantes, podem contribuir para a conservação, ou, ainda, para a recuperação de áreas que já se encontram degradadas. Normalmente, o que ocorre é a utilização dos recursos naturais até o momento em que a exploração econômica se torna insustentável, mesmo com a utilização intensiva de insumos agrícolas. A recuperação natural de áreas degradadas, no que diz respeito à biodiversidade, 
dificilmente ocorrerá sem a intervenção humana. É necessário que os processos de ocupação e exploração das terras sejam orientados, levando-se em consideração não apenas as características do meio físico, mas também os aspectos sociais, de forma a garantir que a exploração do ambiente adote práticas e medidas preventivas de conservação e manutenção dos aspectos produtivos e dos aspectos naturais.

As classes de Potencial de Degradação Ambiental são o resultado da ponderação e integração do mapa geomorfológico, do mapa clinográfico e do mapa de uso e cobertura da terra, resultando em 5 classes de Potencial de Degradação Ambiental.

Classes de Potencial de Degradação Ambiental:

1- nulo

2- baixo

3- moderado

4- alto

5- muito alto 
A relação das Classes de Potencial de Degradação Ambiental com as Classes Geomorfológicas, leva em consideração a seguinte hierarquia de suscetibilidade à ocorrência de processos erosivos (áreas com menor suscetibilidade para áreas de maior suscetibilidade):

- Depressão Paranapanema com solos hidromórficos

- Depressão Paranapanema com Latossolos

- Planalto Atlântico Topo da Serra de Paranapiacaba com Latossolos

- Depressão Paranapanema / Serra dos Lopes com Latossolos

- Planalto Atlântico com Latossolos

- Depressão Paranapanema com Argissolos

- Planalto Atlântico Topo da Serra de Paranapiacaba com Argilossos

- Depressão Paranapanema / Serra dos Lopes com Argissolos

- Planalto Atlântico com Argissolos

- Áreas de Cambissolos e Neossolos Litólicos

Os Argissolos, de forma geral, são mais suscetíveis à erosão que os Latossolos, quando comparados em igualdade de textura e relevo. Os Argissolos são menos permeáveis devido à presença de horizonte $\mathrm{B}$ mais compacto, com acumulação de argila (LEPSCH I. F. - 2002). No caso de Pilar do Sul, a distribuição espacial dos Argissolos em áreas de relevo mais acidentado intensifica, ainda mais, a suscetibilidade à erosão destes solos, quando comparados aos Latossolos.

Os Cambissolos e os Neossolos Litólicos compreendem solos rasos e pouco desenvolvidos, com horizonte $B$ relativamente pouco desenvolvido ou com horizonte A diretamente sobre a rocha. São solos com "cascalhos e pedras", com boa fertilidade, mas o uso com lavoura mecanizada é inviável. Estes solos são “intensamente erodidos após a retirada da floresta nativa. Ocorrem em relevo fortemente ondulado ou montanhoso onde deveria ser conservada a cobertura florestal“ (Bigarella, J. J. - 1985). 
A relação das classes de potencial de degradação ambiental com as classes de uso e cobertura da terra baseou-se na avaliação das perdas de terras associadas ao uso agrícola no Estado de São Paulo (Bellinazzi Jr. et al - 1981 in Bertoni \& Lombardil Neto - 1990). Em função da proteção que a cobertura vegetal oferece ao solo (porte e concentração ou porcentagem de cobertura da terra), da existência de processos erosivos já instalados, do manejo empregado na área e práticas de conservação existentes, é possível estabelecer uma hierarquia de suscetibilidade à erosão (áreas com menor suscetibilidade para áreas de maior suscetibilidade):

- Planícies Aluviais com Vegetação Natural

- Formações Arbóreas (Mata Atlântica)

- Agricultura Perene

- Vegetação Secundária Herbácea/Arbustiva (Campo Antrópico)

- Pastagem com práticas de conservação

- Pastagem

- Silvicultura

- Agricultura Anual com práticas de conservação

- Agricultura Anual

- Pastagem degradada

- Solo Exposto

- Erosão em ravinas

As práticas de conservação de solos são avaliadas de acordo com a eficiência em reduzir os processos erosivos, podendo diminuir o potencial de degradação do ambiente.

As áreas mapeadas como solo exposto são altamente suscetíveis à ocorrência de processos erosivos. Esta classe, juntamente com áreas de erosão em 
ravinas e pastagem degradada, enquadra-se na classe de potencial de degradação muito alto. O solo exposto ocorre, normalmente, nas áreas onde o solo é preparado para implantação de culturas anuais e ainda em áreas onde ocorre a atividade de silvicultura. O processo de atualização e monitoramento dos dados permite a verificação e a determinação do tempo de exposição do solo nu. As áreas mapeadas como solo exposto (Figura 31) são áreas que, nas fotografias aéreas de 2000, estavam com solo exposto mas que, já na imagem de satélite de 1995, também se apresentavam assim, caracterizando áreas onde os processos erosivos atuam de forma intensiva.

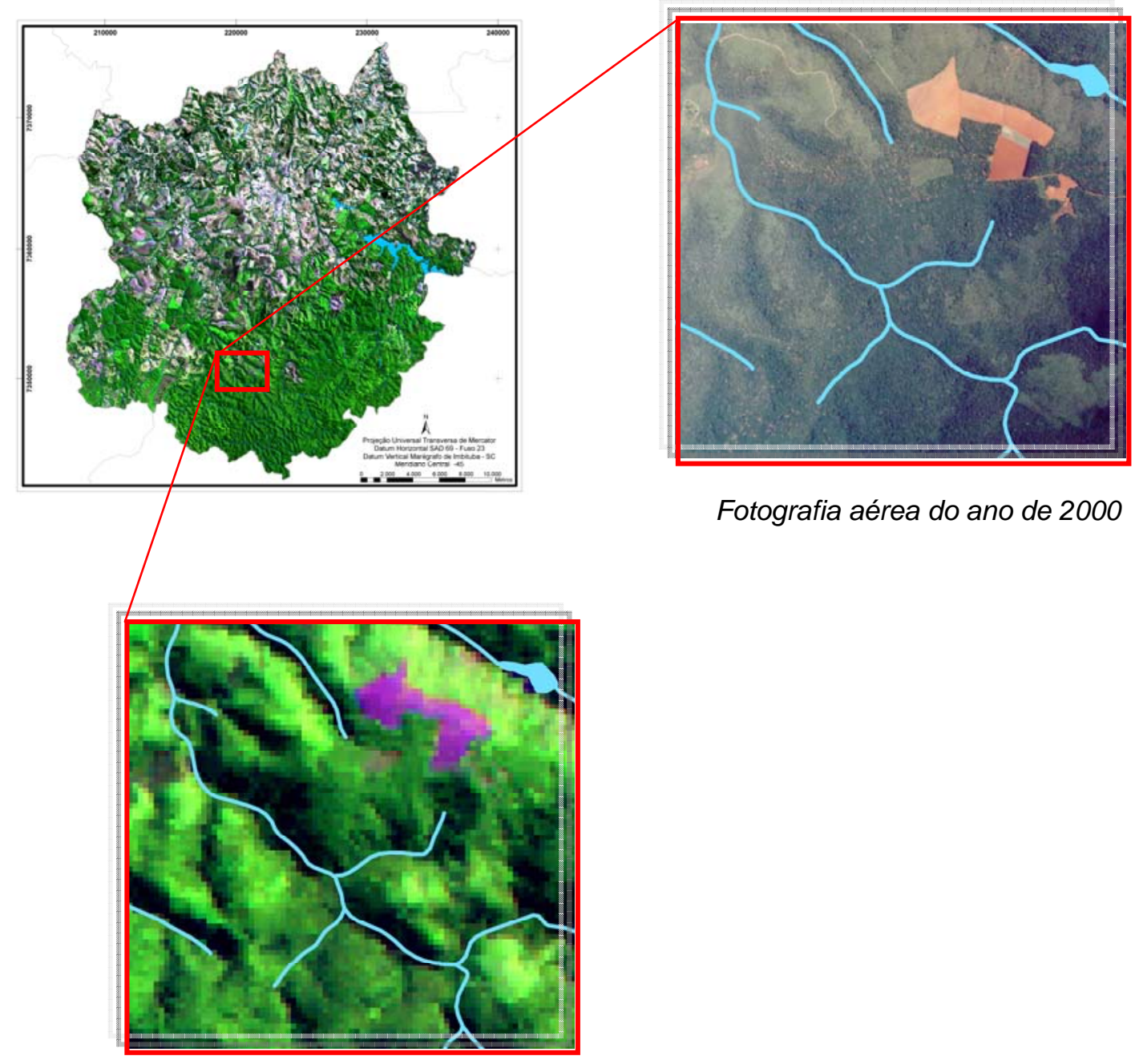

Imagem de satélite LANDSAT do ano de 1995

Figura 31 - Área de solo exposto 
As áreas com declividade maior que 30 \% são áreas sujeitas a processo erosivos agressivos, inclusive com possibilidades de movimentos em massa. Nestas áreas, o potencial de degradação é muito alto, a não ser em casos onde a cobertura vegetal proporcione proteção e estabilidade ao solo.

As classes de uso influenciam o potencial de degradação ambiental de acordo com a hierarquia estabelecida, no entanto ela varia de acordo com a unidade morfológica determinada no mapa geomorfológico.

O Mapa de Potencial de Degradação Ambiental (Figura 32) estabelece potencial nulo para áreas de planície aluvial com vegetação e para áreas de Mata Atlântica, independente do tipo de relevo. 


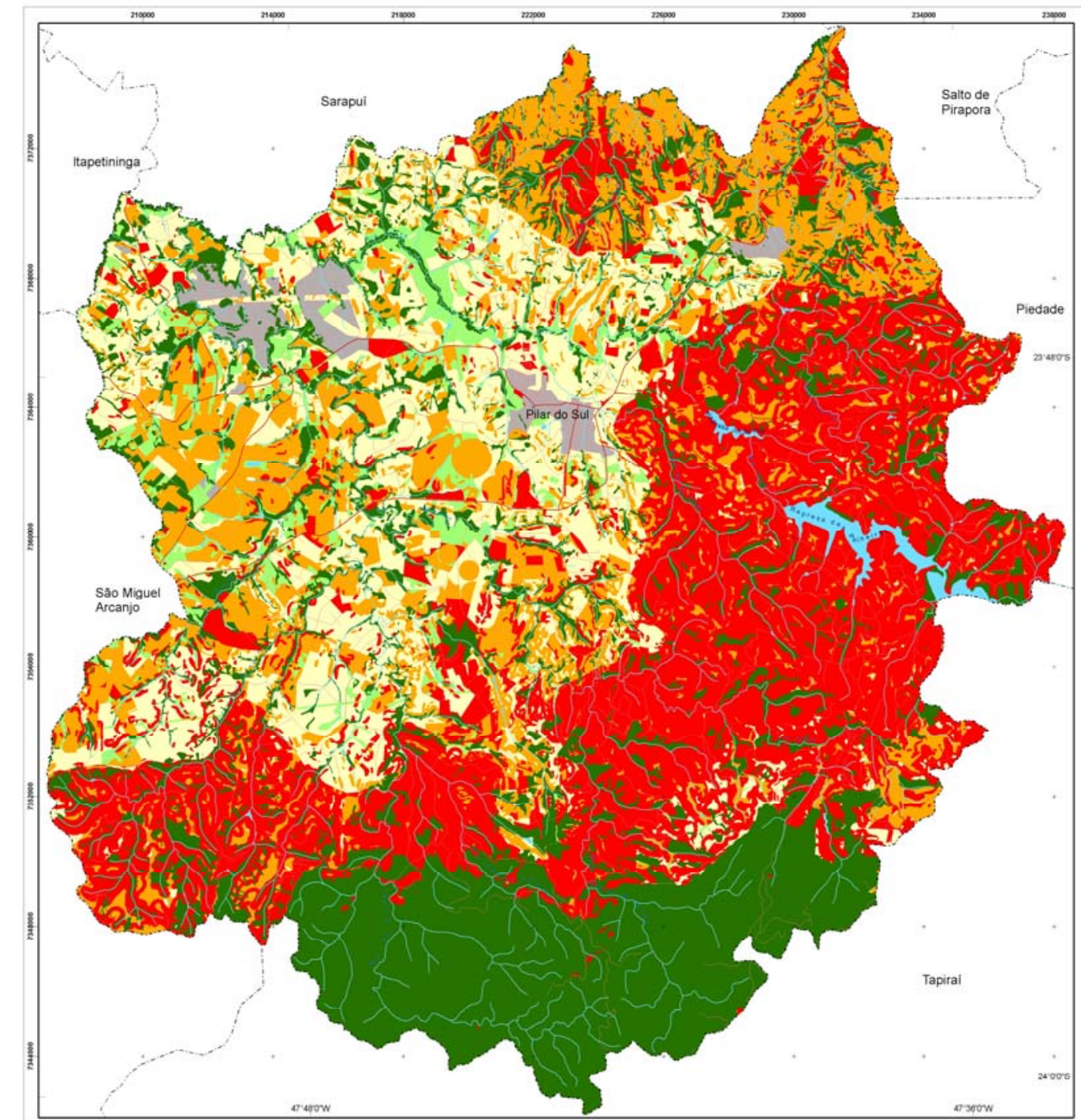

Figura 32

Mapa de Potencial de Degradação

Ambiental

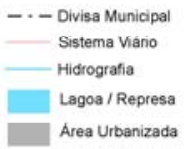

Classes de Potencial de Degradação Ambiental
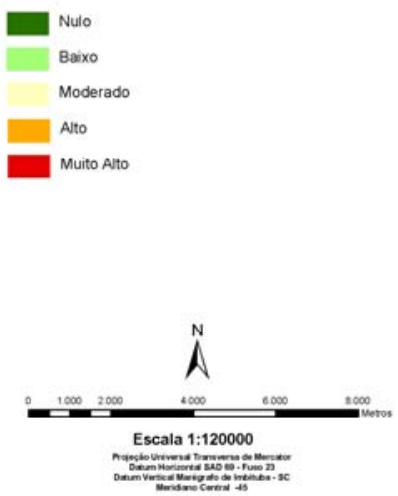

calizaçá do Municipio de Pliar do Su

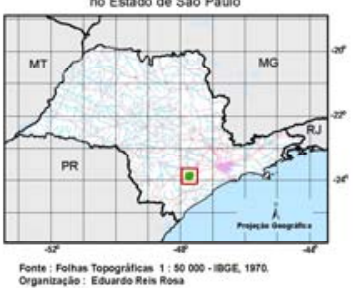




\section{6 - Classes de Capacidade de Uso da Terra}

A definição dos fatores de análise para a elaboração do Mapa de Classes de Capacidade de Uso da Terra de Pilar do Sul foi baseada na proposta de Lepsch (1983), adequando as condições de trabalho disponíveis para a execução do projeto de pesquisa.

O Mapa de Capacidade de Uso da Terra indica o potencial de utilização agrícola, assim como a adaptabilidade das terras para fins diversos, sem que o uso resulte no depauperamento por fatores de desgaste e empobrecimento.

No Sistema de Classificação de Classes de Capacidade de Uso, as necessidades básicas para o estabelecimento da atividade agrícola de forma econômica como, limpeza do terreno, aplicações de corretivos do solo e adubos, eliminação de água sobre superfície do solo, excesso de água no perfil, falta de água, sais solúveis e/ou sódio trocável e riscos de inundações possíveis de serem removidas por melhoramentos menores, ou normalmente corrigidos, não são limitações permanentes e não servem de base para a classificação. Somente onde não for possível melhoramentos menores, as terras devem ser classificadas de acordo com as limitações presentes de uso.

Dessa forma, o nível de manejo admitido é o utilizado nas técnicas agrícolas comprovadas pela experimentação e pesquisa agronômica, ou seja, moderadamente alto, refletindo determinado grau de aplicação de capital e de tecnologia.

As terras agrupadas em uma mesma classe podem ser similares apenas ao grau de limitação para o uso agrícola ou risco de depauperamento do solo, mas podem ter diferentes tipos de solos e requererem diferentes tipos de manejo, sendo necessária a análise da unidade de capacidade de uso, que explicita a natureza da limitação e propõe práticas de manejo.

Observações acuradas, experiências e dados de pesquisa são normalmente usados como auxílio para enquadrar os solos nas classes e subclasses de 
capacidade de uso. Nos locais em que os dados de resposta dos solos aos diferentes sistemas de manejo sejam desconhecidos, o enquadramento nos grupamentos de capacidade de uso é feito com base nas interpretações de suas características e propriedades reconhecidas pelos princípios gerais de uso e manejo desenvolvidos para solos similares, em outras localidades.

Os critérios diagnósticos estabelecidos por Lepsch na "Formula Obrigatória" são os de características pedológicas de profundidade efetiva, textura e permeabilidade, de aspectos erosivos presentes na área, de declividade, de uso atual das terras e de possíveis fatores limitantes encontrados tanto em campo como em laboratório. Em função da classe de solo, associam-se características intrínsecas das suas propriedades que afetam a velocidade de infiltração da água no solo e a resistência do solo à dispersão, que determinam o manejo mais adequado, assim como a sua capacidade de uso.

Os solos são avaliados segundo características de profundidade efetiva que pode ser um fator limitante no uso e importante na determinação da capacidade de armazenamento de água e de elementos nutritivos para a rizosfera. O caso de solos sobre rocha consolidada (contato lítico) dificulta e até inviabiliza a implantação de culturas, dependendo do tipo de cultura e da profundidade em que se encontra a rocha ou lençol freático. No caso de solos muito rasos, a limitação está na dificuldade de penetração das raízes.

A textura é uma característica dos solos determinada pelas proporções de argila, silte e areia existente na fração mineral. São dependentes da textura características como: estrutura, consistência, permeabilidade, capacidade de retenção de água e capacidade de troca de cátions. Solos com diferentes texturas podem apresentar diferentes comportamentos no que diz respeito às relações entre solo, água, ar e plantas. A variação na textura pode ser de solo para solo ou, também, entre os horizontes de um mesmo solo. A permeabilidade tem grande importância no conhecimento dos movimentos da água e do ar no solo e, conseqüentemente, no desenvolvimento das plantas. A fertilidade aparente do solo expressa a capacidade do solo de oferecer condições favoráveis ao bom desenvolvimento das plantas. 
O grupamento no sistema de capacidade de uso das terras não reflete um uso econômico da terra ou o seu valor econômico e não supõe uma relação de produtividade para cultivos específicos.

As classes de capacidade de uso estão sujeitos a mudanças à medida que se obtêm novas informações técnicas sobre o comportamento dos solos e da dinâmica do ambiente.

Terras classificadas como apropriadas para o estabelecimento de práticas agrícolas podem, também, ser utilizadas para pastagens, silvicultura ou proteção da vida silvestre.

Para a elaboração do mapa de Capacidade de Uso da Terra de Pilar do Sul, foram adaptados critérios e parâmetros propostos por LEPSCH (1983), que prevê a classificação das terras em 8 classes, sendo elas:

CLASSES I, II, III e IV - Terras passíveis de serem utilizadas com culturas anuais, perenes, pastagens, silvicultura e vida silvestre, diferenciando-se segundo alguns parâmetros definidos a seguir:

\section{CLASSE I}

- Terras sem problemas de conservação do solo.

- Áreas praticamente planas (até 2\%).

- Próprios para culturas anuais.

- Solos :

- produtivos.

- profundos.

- bem drenados.

- sem erosão aparente. 
- baixa suscetibilidade à erosão.

- sujeitos à erosão por lixiviação.

- sujeitos à deterioração da estrutura.

- sem pedras.

- não suscetíveis a inundações.

\section{- Práticas de manejo para conservacão do solo e controle da erosão:}

- plantio em nível;

- rotação de culturas;

- capinas;

- tratos culturais normais;

- controle de queimadas;

- adubação verde;

- adubação orgânica;

- calagem para correção da acidez do solo;

- aplicação de corretivos e fertilizantes;

- controle de pragas e doenças;

- O uso sucessivo da mesma área para cultivo anual impõe a necessidade de adoção de práticas constantes de manutenção da fertilidade do solo.

- No caso da silvicultura deve-se ter cuidados especiais no preparo do solo, adotando técnicas de contenção do fogo, conservação de estradas de acesso, corte sistemático e o desenvolvimento de métodos de regeneração do plantio que preservem o solo. 
CLASSE II

- Problemas simples de conservação do solo.

- Declividades de $2 \%$ a 5\%, porém suficiente para provocar enxurradas.

- Solos:

- produtivos.

- suscetíveis à erosão.

- Práticas de manejo para conservação do solo e controle da erosão:

- as citadas na Classe I, porém com possíveis intensificações e associaç̃̃es.

- plantio de cultura em faixas;

- manutenção da vegetação residual, evitando deixar o solo exposto;

- implementação de terraços em nível, de base larga e com vegetação;

- implementação de drenagem artificial através de canais escoadores associados ou não aos terraços, porém sem necessidade de práticas complexas de manutenção dos drenos;

- adoção de quebra ventos com o plantio de árvores adensadas formando uma barreira natural à ação dos ventos;

- plantio direto; 


\section{CLASSE III}

- Problemas complexos de conservação do solo, principalmente no caso de culturas anuais.

- Declividades de 5\% a 12\%, sem restrições à mecanização.

- Solos:

- produtividade razoável, quando adotando práticas de conservação e culturas adaptadas.

- suscetível à erosão.

- Práticas de manejo para conservação do solo e controle da erosão:

- as citadas nas Classes I e II porém com possíveis intensificações e associações.

- pedregosidade: pode ser um fator limitante, dificultando a mecanização total, ou exigindo a remoção de pedras;

- melhoramento das condições físicas do solo, através da incorporação de matéria orgânica ou ainda com a rotação utilizando culturas de raízes profundas e com grande quantidade de resíduos vegetais;

- implementação de cordões de contorno;

- manutenção intensiva dos drenos ou canais escoadouros e terraços;

- utilização de plantas em cobertura viva ou morta;

- utilização do consorciamento de culturas ou plantio misto;

- otimização do uso do solo nas entre linhas;

- menor espaçamento na implantação de culturas;

- adubações pesadas;

- irrigação. 
CLASSE IV - Limitações permanentes muito severas quando usadas para culturas anuais. A adoção de cuidados muito especiais, no entanto, permite a prática de cultivos ocasionais.

- Sérios problemas de conservação do solo.

- Declividades de 12\% a 20\% com restrições à mecanização.

- Solos:

- em geral pouco produtivos ou podem ter fertilidade natural boa ou razoável, mas não são adequados a cultivos intensivos e contínuos.

- não devem ser arados todos os anos, podendo ser melhor utilizados com culturas perenes e pastagens com práticas intensivas de proteção ou ainda com culturas em rotação ou em consórcio com pastagem e florestas

- pequena profundidade dos solos.

- erosão acentuada.

- drenagem deficiente.

- Práticas de manejo para conservação do solo e controle da erosão:

- as citadas nas Classes I, II e III porém com possíveis intensificações e associações.

- plantio de cordões de vegetação permanente com plantas de crescimento denso em contorno a área cultivada;

- alternância de capinas de maneira a manter parcelas da área de cultivo com cobertura vegetal;

- atenção especial ao espaçamento entre os terraços. A variação se estabelece conforme o tipo de solo, os aspectos erosivos presentes, a cultura a ser implantada, a declividade da área e o comprimento de rampa da área cultivada. Associados aos terraços, a utilização de canais de escoamento 
vegetados auxiliam no transporte e escoamento da água, sendo necessária a intensa manutenção da vegetação nos terraços e drenos (Galeti, P. A. 1973).

- no caso de pastagens, deve-se intensificar o controle do números de cabeças de gado/hectare e o rodízio do pastoreio;

- rotação de pastagem com culturas anuais;

- cuidados especiais na manutenção da capacidade produtiva da área.

CLASSE V - Terras impróprias para cultivos intensivos, mas ainda adaptadas para casos de algumas culturas permanentes, pastagens e florestas.

- Áreas com culturas anuais ocasionais, cultivo de algumas culturas permanentes em casos especiais e adaptação de culturas em rotação com pastagens e florestas, sendo próprias para pastagens e florestas.

- Áreas planas

- Solos:

- boa fertilidade.

- pequena profundidade efetiva.

- não sujeitos à erosão.

- problemas de drenagem, sendo sujeitos à inundação freqüente.

- muito pedregosos.

- Sem restrições ao uso para pastagens e florestas.

- Desobstrução de drenos naturais.

- Sem necessidade de manejo complexo para produções satisfatórias. 
CLASSE VI - Terras impróprias para cultivos intensivos, mas ainda adaptados para casos de algumas culturas permanentes quando adotando práticas especiais de conservação e proteção do solo e aptos a pastagens com restrições moderadas ao uso e florestas.

- Declividade de $20 \%$ a 47\%, com restrições à atividade agrícola mecanizada.

- Solos:

- baixa produtividade

- problemas com pedregosidade.

- rasos

- suscetíveis a processos erosivos severos

- Práticas de manejo para conservação do solo e controle da erosão:

- as citadas nas Classes I, II, III e IV, porém, com restriç̃es no uso e na implementação de determinadas técnicas, visando intensificar técnicas eficientes, associando-as de forma adequada que, integradas, contribuem para a conservação do ambiente. 
CLASSE VII - Terras somente aproveitáveis para pastagens ou florestas, porém com severas restrições ao uso. A produtividade pode ser boa, porém, no geral com declividades muito íngremes (acima de 47\%), ou muito erodida, ou ainda muito pedregosa ou com solos rasos e, ainda, com deficiência muito grande de água.

Os cuidados necessários são semelhantes aos citados anteriormente, porém, com maior associação de práticas conservacionistas, ou que estas sejam mais intensivas, a fim de prevenir, diminuir ou recuperar os danos por erosão. O uso com pastagens exige muito cuidado; recomenda-se silvicultura, mas sempre com cuidados especiais. São áreas impróprias para agricultura, não sendo permitida a derrubada de floresta, "só sendo nelas toleradas a extração de toros quando em regime de utilização racional que vise a rendimentos permanentes" (Código Florestal, 1965).

CLASSE VIII - Solos impróprios para qualquer exploração agrícola, servindo apenas de abrigo para vida silvestre, ou recreação.

Servem somente para abrigo da vida silvestre ou recreação e turismo. São terras de afloramentos de rocha, brejos, pântanos, declives excessivamente íngremes, ou severamente erodidos.

Para o enquadramento das terras em classes de capacidade de uso, consideram-se os efeitos das características individuais da terra, hierarquizando os parâmetros de acordo com prioridades estabelecidas de acordo com as análises dos mapas geomorfológico, clinográfico e de uso e cobertura da terra. 


\section{1 - Fatores limitantes}

Os solos presentes no Município impossibilitam o enquadramento nas classes I e II de capacidade de uso, por terem problemas de fertilidade, serem suscetíveis a erosão e necessitarem de práticas complexas de controle. Dessa forma, os Latossolos foram enquadrados na classe III de capacidade de uso da terra.

A presença de processos erosivos (classe de uso e cobertura vegetal de erosão em ravinas e solo exposto) é um fator limitante que implica na adoção de práticas de conservação dos solos para possibilitar o uso de forma econômica. Essa situação classifica a área na classe VII de capacidade de uso da terra.

A pedregosidade do solo indica maior ou menor facilidade para o trabalho das máquinas agrícolas, sendo a análise baseada na descrição do tipo de solo e das observações de campo, definindo a porcentagem de pedras na área. No Município, os Argissolos presentes na área da Serra do Lopes estão sujeitos a problemas de pedregosidade.

As áreas de campo antrópico não são consideradas produtivas por serem locais onde a vegetação secundária está em desenvolvimento e por serem áreas onde as condições antrópicas impossibilitam o uso de forma exploratória para fins comerciais. Eventualmente são utilizados como pastagem, porém, de baixa produtividade.

A análise desse mapa demostra claramente a existência dos dois ambientes geomorfológicos:

- a Depressão Periférica, com áreas classificadas prioritariamente na classe III, com ocorrência de classe IV nos setores de maior declividade;

- o Planalto Atlântico, onde predominam as áreas de classe VI com setores de classe VII em decorrência da alta declividade do relevo e, ainda, alguns pequenos setores de classes IV e III, associados a áreas de menor declividade.

O Mapa de Classes de Capacidade de Uso da Terra é apresentado na Figura 33. 


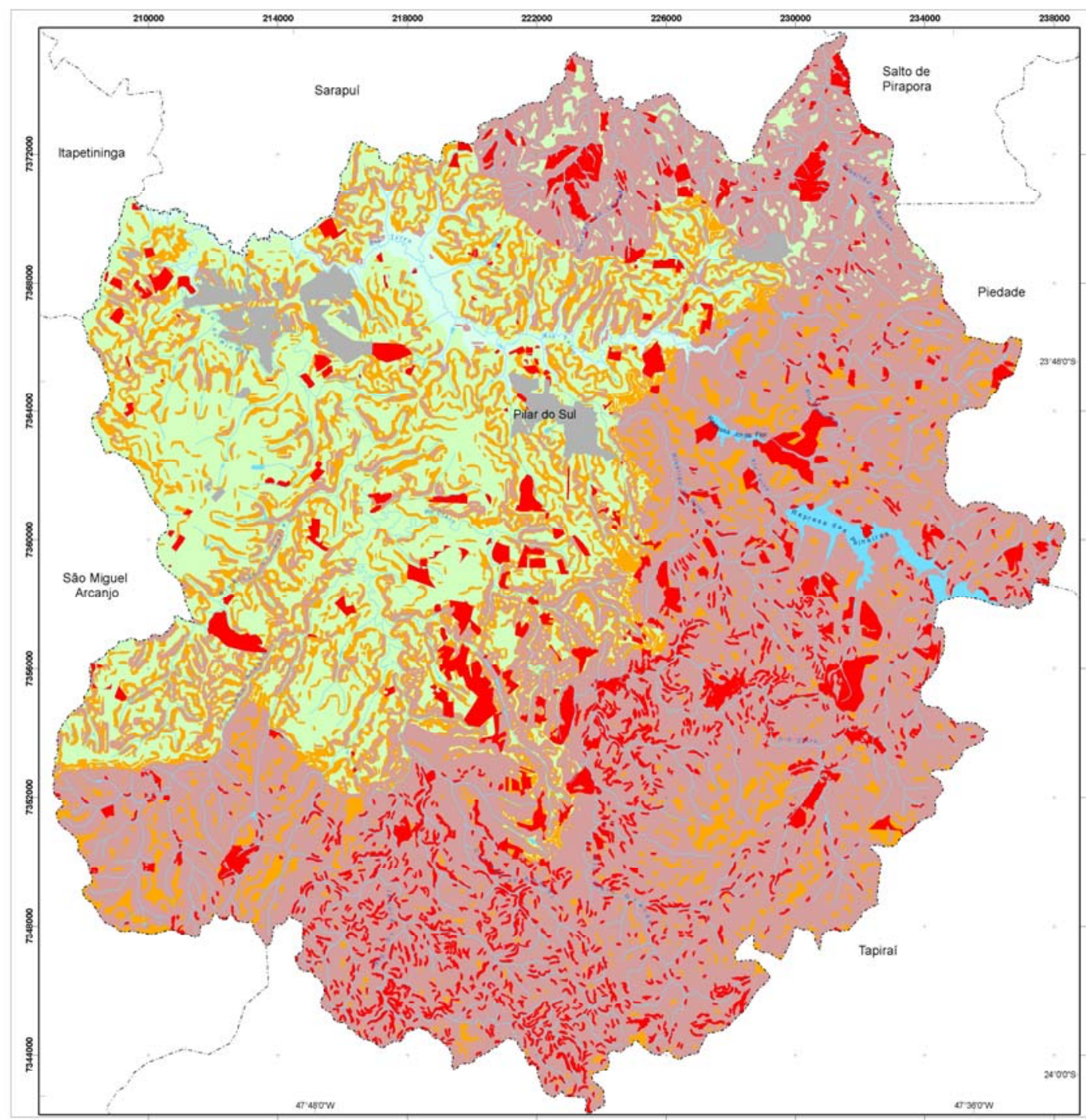

Figura 33

Mapa Capacidade de Uso da Terra

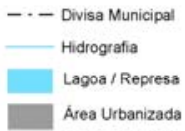

Classes de Capacidade de Uso da Terra

Classe III - Terras passiveis de serem utilizadas com culturas anuais, perenes, pastagens, sivicultura e vida silvestre
Problemas complexos de conservaça do solo, principalmente no caso de culturas anuais
Declividade $<12 \%$ sem restriç̧es à mecanizaçăo

Classe IV - Terras passiveis de serem utilizadas com culturas anuais, Limitacces permanentes muto severas quando usadas para culturas an porém a adoçấo de cuidados muito especiais permitem a prática de cultivos ocasionais
Declividades de $12 \%$ a $20 \%$ com restriçbes à mecanizaçăo

Classe $\mathrm{V}$ - Terras impróprios para cultivos intensivos, mas ainda adaptados a culturas anuais ocasionais, para casos de algumas culturas permanentes em casos especiais, sendo proprios para pastagens e forestas Areas planas

Classe VI - Solos impróprios para cultivos intensivos, mas ainda adaptados para casos de algumas culturas permanentes quando adotando práticas especiais de conservaçáo e proteçåo do solo e aptos a pastagens com restriçes moderadas ao us

Classe VII - Solos somente aproveitáveis para pastagens ou florestas, porém com severas restricoes a uso. A produtvidade pode ser bos. porem, no get com dedividades muito ingremes (acima de $47 \%$ ), ou muito erodida, ou ainda muito pedregosa ou com solos rasos

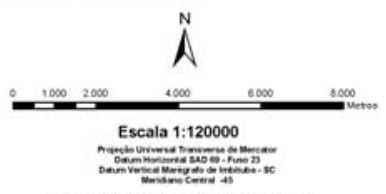

Localizaça do Municipio de Plar do Sul

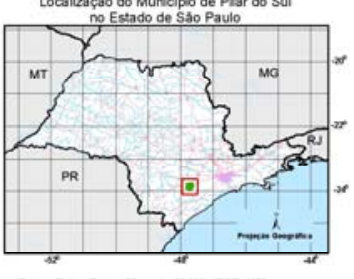

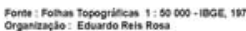




\section{Zoneamento Agroecológico}

Para a elaboração do Zoneamento Agroecológico é fundamental o estabelecimento de normas de uso e preservação dos mananciais e dos recursos naturais que ainda restam no Município.

A definição de normas rígidas corre o risco de não serem cumpridas e de rapidamente se tornarem obsoletas em face à dinâmica da ocupação (Becker 1997). Dessa forma, a participação social contribui para a consolidação da legislação ambiental, na medida em que a população e principalmente os setores mais envolvidos da comunidade, discutem as propostas e se conscientizam da necessidade de se adotarem medidas de conservação e de proteção do solo.

O Mapa de Zoneamento Agroecológico foi o resultado da integração das seguintes informações anteriormente levantadas: mapas clinográfico, hipsométrico, geomorfológico, uso e cobertura da terra, potencial de degradação ambiental e de capacidade de uso das terras. A tabela 2 mostra a chave de classificação para o estabelecimento do Zoneamento Agroecológico. 


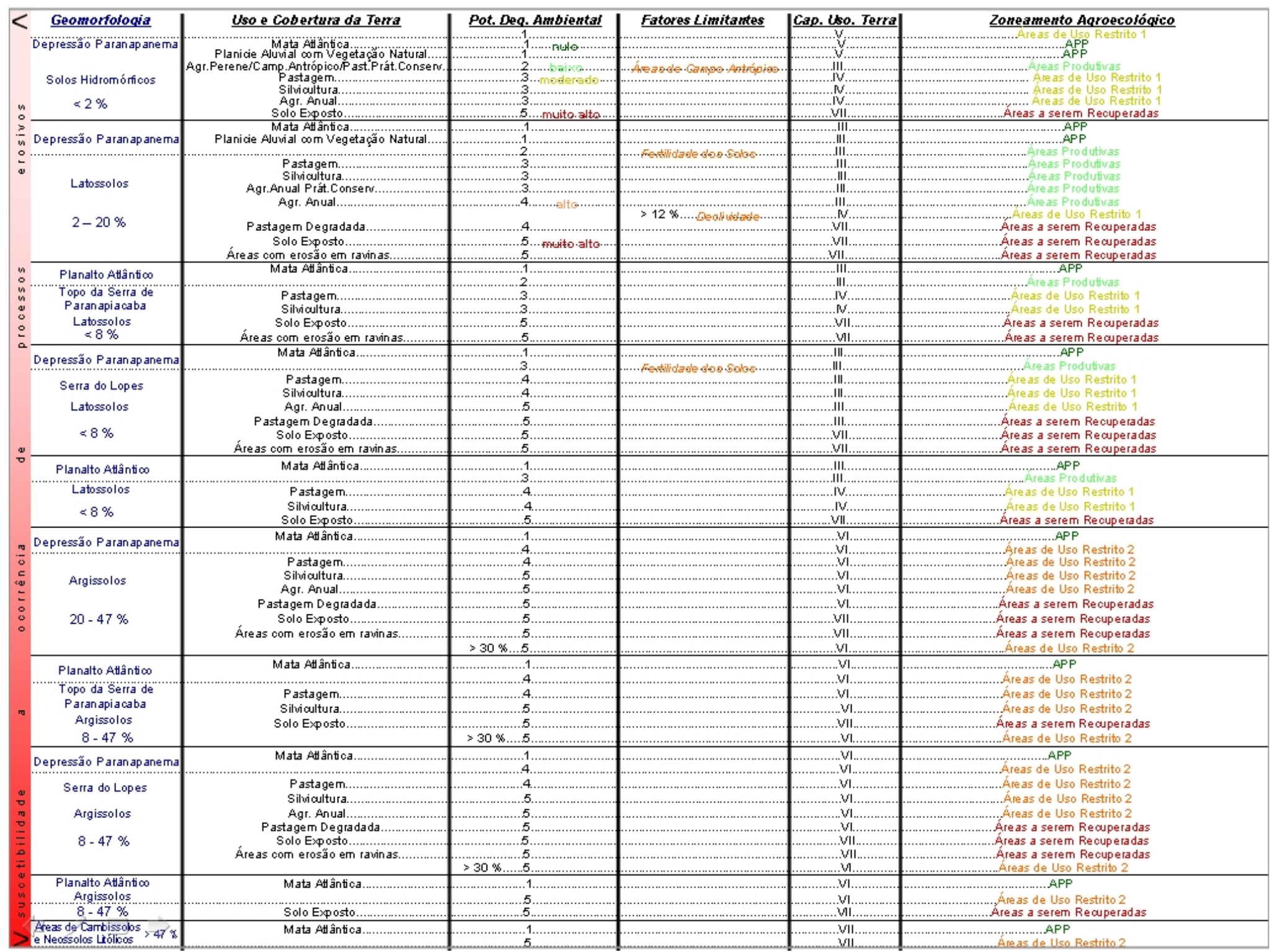


A Figura 34, ilustra uma aproximação do mapa de Zoneamento Agroecológico estabelecido para o município de Pilar do Sul.

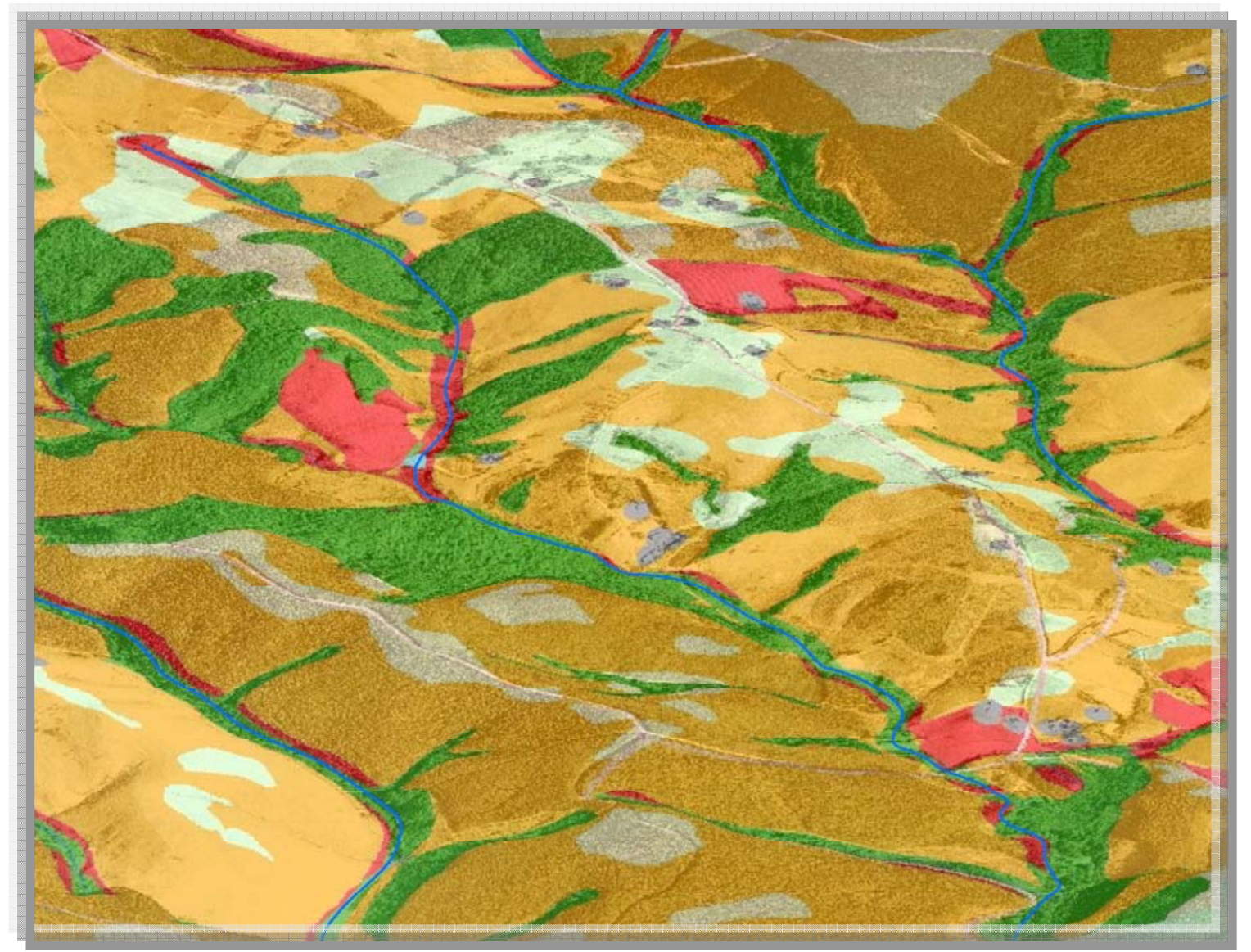

Figura 34 - Visualização tridimensional do mapa de Zoneamento

A espacialização das classes de Zoneamento mostra em laranja (Uso Restrito 2) as áreas cultiváveis apenas em casos especiais de algumas culturas permanentes e adaptadas, próprias para pastagem e silvicultura. Nestas áreas, é necessário o emprego intensivo de práticas de conservação dos solos de acordo com as recomendadas na Classe VI de Capacidade de Uso da Terra; são áreas com declividades $>20 \%$, sendo muito suscetíveis à ocorrência de processos erosivos.

As áreas em bege claro (Uso Restrito 1) são áreas aptas a atividades agropecuárias com restrições a culturas anuais, podendo ser cultivadas com a adoção de cuidados muito especiais, com a prática de cultivos ocasionais, com o 
emprego de práticas de conservação dos solos complexas de acordo com as recomendadas na Classe IV de Capacidade de Uso da Terra.

As áreas em verde claro são áreas aptas à atividade agropecuária sem restrições de uso, sendo, no entanto, indispensável o emprego de práticas de conservação dos solos de acordo com as recomendadas na Classe III de Capacidade de Uso da Terra.

Em vermelho, são áreas a serem recuperadas, identificando áreas com a presença de processos erosivos ou ainda áreas de pastagem, áreas agrícolas, áreas de silvicultura, de solo exposto, de pastagem degradada e áreas de erosão em ravinas dentro de Áreas de Preservação Permanente.

Em verde, destacam-se as áreas de Mata Atlântica e, em cinza, as áreas antropizadas.

Além das áreas urbanizadas que são definidas e disciplinadas pelo Plano Diretor de Uso e Ocupação do Solo, o Zoneamento Agroecológico (Figura 35), como resultado do presente trabalho, aponta para a existência de dois grandes blocos de áreas destinadas a atividades agropecuárias;

- setores da Depressão Periférica com declividades inferiores a 12\%, que não oferecem restrições ao uso agropecuário e que foram classificados na classe III de capacidade de uso da terra;

- setores do Planalto Atlântico com declividades maiores de 20\%, próprios para pastagem e silvicultura, com restrições para culturas, classificados na classe VI de capacidade de uso da terra;

Ambos setores apresentam trechos que escapam a essa classificação genérica em função das variações de inclinação do terreno:

- na Depressão Periférica, ocorrem estreitas faixas, geralmente paralelas à drenagem, com declividade acima de $12 \%$, que oferecem restrições às culturas anuais: correspondem à Classe IV e Classe VI no mapa de Classes de Capacidade de Uso da Terra; 


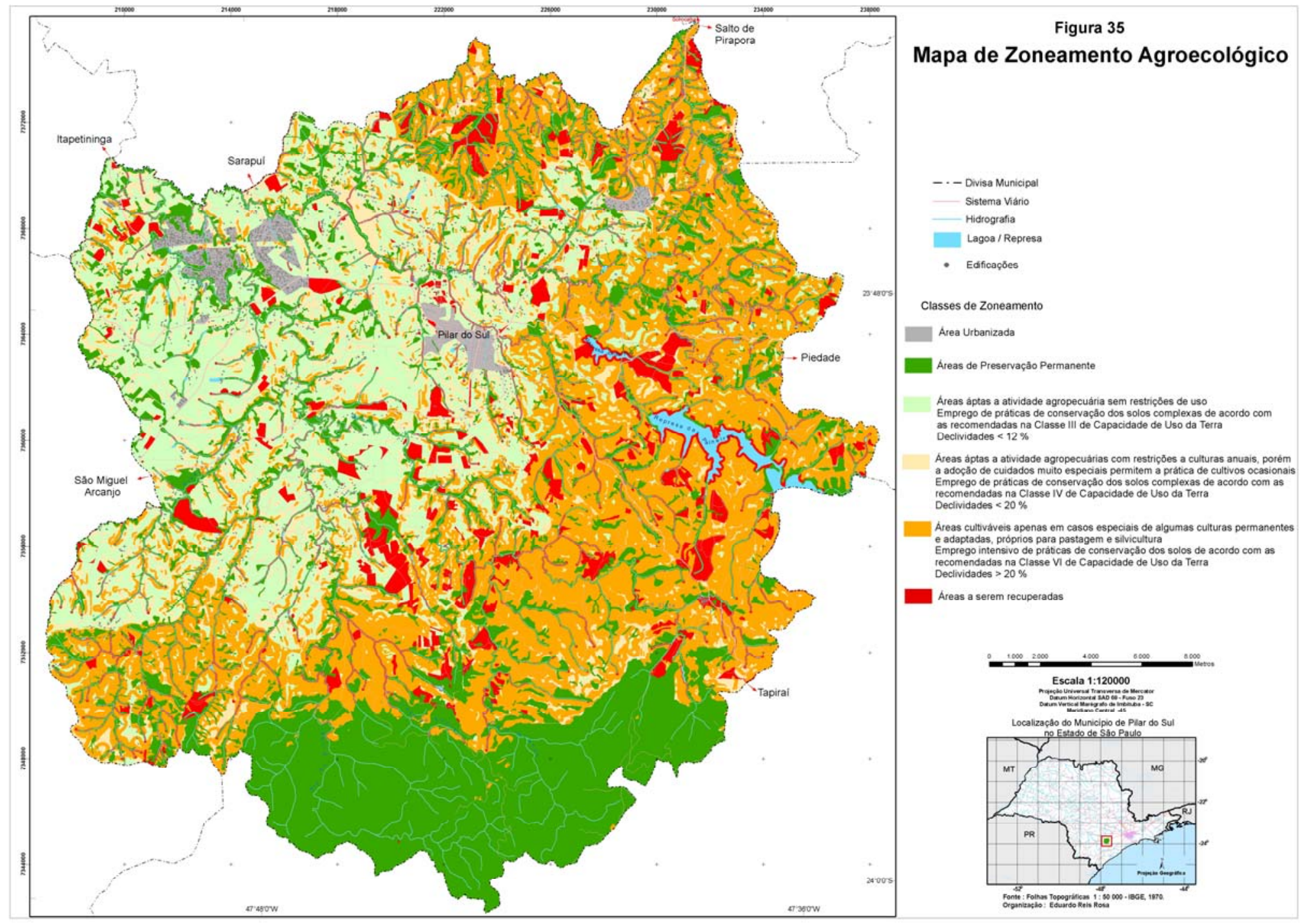


- no Planalto Atlântico, ocorrem pequenos trechos de declividades menores que 20\%, que se enquadram nessa mesma condição (Classe IV) e restritas áreas de Classe III.

As áreas de preservação permanente são aquelas definidas pela legislação federal, Código Florestal e Resolução número 4 do CONAMA - Conselho Nacional do Meio Ambiente, que através de dispositivos legais, visa à conservação dos recursos naturais, através da orientação do uso do solo, da água e do ar.

O apoio legal de preservar as áreas de Mata Atlântica que ainda restam no Município, é o DECRETO no 750 de 10 de fevereiro de 1993, que dispõe sobre a proibição do corte, exploração e a supressão de vegetação primária ou nos estágios avançado e médio de regeneração da Mata Atlântica, a não ser em situação autorizada mediante decisão motivada do órgão estadual competente, com anuência prévia do Instituto Brasileiro do Meio Ambiente e dos Recursos Naturais Renováveis - IBAMA, informando-se ao Conselho Nacional do Meio Ambiente CONAMA e mediante aprovação de estudo e relatório de impacto ambiental.

O decreto $n^{\circ} 750$, não se mostra suficiente para combater as ações predatórias em relação à Mata Atlântica, pois deixa lacunas no que diz respeito a questões relacionadas ao uso, proteção e recuperação do bioma. É necessário o estabelecimento de restrições, que compatibilizem a presença do homem com a proteção do recurso natural, através da regulamentação do uso.

O movimento ambientalista vem insistindo na aprovação do Projeto de Lei da Mata Atlântica (PL 285/99), que cria novas restrições à supressão e utilização da vegetação e em uma série de mecanismos de incentivo à preservação e recuperação do bioma.

O Código Florestal (Lei $n^{0} 4.771$ ) incide de forma generalizada sobre todas as florestas brasileiras, deixando margem para que o processo de desmatamento não seja freado. Estas áreas são destinadas à preservação da vegetação, das nascentes e margens fluviais, protegendo os recursos hídricos, a paisagem e a estabilidade geológica, protegendo o solo de aspectos erosivos e conservando a biodiversidade, o fluxo gênico de fauna e flora e o bem estar das populações 
humanas. A Resolução número 4, do CONAMA, de 18/09/1985 transformou estas áreas em reservas ou estações ecológicas pela Lei Federal número 6.938, de 31 de agosto de 1981.

Entre outras atribuições do Código Florestal, destacam-se:

Art. $\mathbf{2}^{\circ}$ - Consideram-se de preservação permanente, pelo só efeito desta Lei, as florestas e demais formas de vegetação natural situadas:

- de 30 metros para os cursos d'água de menos de 10 metros de largura;

- de 100 metros ao redor das lagoas, lagos ou reservatórios d'água naturais ou artificiais;

- nas nascentes, ainda que intermitentes e nos chamados "olhos d'água", qualquer que seja a sua situação topográfica, num raio mínimo de 50 metros de largura.

O Município de Pilar do Sul se enquadra dentre os municípios que possuem uma Área Natural Tombada que pertence à Área de Proteção Ambiental - APA Estadual da Serra do Mar (IPT - 1992), decreto $n^{0} 22717$ de 21/09/84, que tem como objeto de preservação a Mata Atlântica. No entanto, analisando o memorial descritivo contidos nos decretos de sua criação que definem seus limites e cujas referências encontram-se na base cartográfica do IBGE, o Parque, tem o município de Pilar do Sul, justamente como referencia do limite do Parque, que passa pela divisa intermunicipal de São Miguel Arcanjo / Pilar do Sul / Tapiraí e segue pela divisa municipal de Pilar do Sul / Tapiraí, excluindo o Município de Pilar do Sul. 


\section{Considerações Finais}

Um plano de ação para a conservação da biodiversidade deve levar em conta não somente os aspectos naturais da região, como as espécies, os recursos hídricos, os ciclos naturais da floresta, e os aspectos sócio-econômicos que têm grande influência sobre o ecossistema, determinando, assim, as pressões ambientais presentes.

A pesquisa apresenta mapeamentos que auxiliam na execução de projetos que tratam das questões ambientais, mostrando que com a análise das diferentes características atribuídas a uma determinada área, é possível estabelecer áreas a serem priorizadas.

A Prefeitura de Pilar do Sul, através da Casa de Agricultura e em parceria com o Instituto ECOAR, desenvolve o projeto "Floresta da Família", onde estimula-se a incorporação do conceito de desenvolvimento sustentável, através de técnicas de produção Agro-Pastoril-Florestal. Com o incentivo, estímulo e capacitação de instituições e agricultores objetiva-se criar condições de implantação, condução, manejo e desenvolvimento dos projetos florestais, para fins de produção e conservação (Diretoria de Agropecuária e Meio Ambiente de Pilar do Sul - 2005).

Práticas agrícolas de conservação do solo, assim como a adoção de medidas preventivas de controle da erosão, devem fazer parte do processo de planejamento e implantação dos campos de produção. O objetivo do estabelecimento de práticas e medidas de controle da erosão é garantir que a água das chuvas ou da irrigação não se torne um problema e siga o seu curso normal, ou seja, infiltrando ao máximo no solo, abastecendo o lençol freático e, por conseqüência, os cursos d'água. O controle da erosão deve ser efetuado através de uma ação efetiva de caráter corretivo, seguido de outra, de caráter preventivo.

As medidas de controle e prevenção da erosão dos solos podem ser de caráter vegetativo, edáficas ou mecânicas. As medidas de controle devem se adequar à capacidade de uso das terras, adaptando-se às características físicas e químicas dos solos, assim como à declividade, comprimento de rampa, tipo de cultivo e demais informações das potencialidades e limitações dos recursos. 
Nas atividades agrícolas, o controle da erosão é uma medida básica e prioritária a ser tomada. Medidas subseqüentes e identificadas em Pilar do Sul como, escolha de sementes melhoradas, utilização de mudas fiscalizadas, técnicas de plasticultura, adubações mineral, orgânica e verde, pouco adiantam se os processos erosivos estão presentes na área.

O levantamento de dados e os mapeamentos conduziram ao mapa Zoneamento Agroecológico que diferencia áreas de acordo com suas condições de uso e existência e manutenção dos recursos naturais. As áreas com alto potencial de degradação são sujeitas a maior influência dos processos erosivos e, dessa forma, é preciso compatibilizar as atividades econômicas para cada área em específico. Planos de recuperação ambiental de áreas degradadas devem ser contemplados, assim como o uso de técnicas de conservação dos solos.

"As áreas de preservação permanente, vertentes fortemente inclinadas, margens fluviais e áreas de mananciais exigem soluções estratégicas de mais amplo espectro, privilegiando a solução de problemas de processos erosivos, assoreamento, mineração, caça e pesca, turismo, qualidade da água, agricultura, pecuária, desmatamentos, expansão de fronteira agrícola, atividades industriais diversas, seneamento básico, reciclagem dos resíduos e líquidos, entre inúmeros outros" (ROSS, 1993).

A adoção das práticas de manejo citadas (Mapa de Classes de Capacidade de Uso da Terra) com maior intensidade, em maior número e associadas, ajudam na prevenção de danos ao meio ambiente causados pelos processos erosivos. Em áreas de silvicultura, a possibilidade de cultivos entre linhas deve ser levada em consideração, especialmente nas épocas de corte, quando a exposição do solo acontece. O estabelecimento de pastagem com práticas mínimas de conservação, como curvas de nível, garante uma boa condição de proteção do solo. O controle do pastoreio e a divisão dos pastos são medidas de manejo que, adotadas, garantem a boa manutenção na implantação das pastagens. As áreas de cultura anual na Depressão Periférica são áreas onde a renovação das plantações implica em revolvimento do solo, tornando-o exposto e suscetível à ocorrência dos processos erosivos. $\mathrm{Na}$ interpretação das fotografias aéreas, as áreas de solo exposto, onde 
era evidente o fato de ser uma operação de preparação do solo para cultivo, foram mapeadas como agricultura anual. O cultivo anual, no entanto, sem a adoção de práticas de manejo adequadas causam prejuízos aos solos, muitas vezes irreversíveis. A conseqüência é a existência de áreas degradadas nas quais o emprego de práticas simples de conservação poderia garantir a continuidade da exploração agrícola.

O Zoneamento Agroecológico é um importante instrumento de planejamento que auxilia no processo de gestão territorial, na medida em que recomenda o uso e ocupação racionais da terra, com base nas suas características físico-naturais e sócio-econômicas, identificando, inclusive as áreas que devem ser recuperadas em função dos processos de degradação já instalados e as áreas que devem ser preservadas.

Através da integração das informações com as técnicas de geoprocessamento é possível ter uma visão geográfica do ambiente. A utilização dos sistemas de informações geográficas no gerenciamento do território não é só viável como recomendável, representando maior agilidade e precisão na tomada de decisões e, ainda, um aumento nas possibilidades de controle e integração de ações para o desenvolvimento social e para a conservação ambiental.

As escalas de análise em SIG variam de acordo com o interesse e a necessidade. O projeto de pesquisa utilizou base topográfica de 1:50000 e os mapas finais apresentados em 1:120000. Em alguns casos, foi necessária a generalização cartográfica, eliminando polígonos muito pequenos que causam ruídos nos mapas e dificultam a leitura. No entanto, o fato de ser um projeto em SIG, a análise em ambiente digital (microcomputadores) da área mapeada permite visualizações e análises em escalas maiores. Com as fotografias aéreas, por exemplo, é possível chegar a detalhes de delimitação de propriedades em áreas urbanas, podendo contribuir na atualização, manutenção e controle do cadastro imobiliário urbano. Esse grau de detalhe não foi abordado, por ser este, um projeto de caráter ambiental, mas o aprofundamento e até mesmo a geração de uma base topográfica em maior escala são procedimentos que adicionarão informações ao SIG e possibilitarão análises mais detalhadas. 
Como alternativa tecnológica à disposição dos municípios, os softwares de domínio público possibilitam trabalhar com as informações organizadas neste projeto de pesquisa e atualizar os fatores dinâmicos, o que é fundamental para que as análises e interpretações permaneçam consistentes ao longo do tempo. Os Sistemas de Informações Geográficas constituem uma tecnologia indispensável para a integração de aspectos multidisciplinares de estudos ambientais e um instrumento de suma importância para as atividades de planejamento, pois a sua utilização pode conferir agilidade e eficiência no processo de gestão territorial. 


\section{Referências bibliográficas}

- AB'SABER, Aziz N. - Geografia e Planejamento - no 2 Instituto de Gegrafia FFLCH / USP - São Paulo - 1969.

- AB'SÁBER, Aziz N. - A Depressão Periférica Paulista: um setor das áreas de circundesnudação pós-cretácica na Bacia do Paraná. Geomorfologia - n⿳ํㅡ 15 Instituto de Geografia Universidade de São Paulo - 1969.

- AB'SÁBER, Aziz N. - Um Conceito de Geomorfologia a Serviço das Pesquisas sobre o Quaternário. Geomorfologia - nº 18 - Instituto de Geografia Universidade de São Paulo - 1969.

- AB'SABER, Aziz N. - Províncias Geológicas e Domínios Morfoclimáticos no Brasil - Geomorfologia - nº 20 Instituto de Geografia - FFLCH / USP. São Paulo - 1970.

- AB'SABER, Aziz N. - A Organização Natural das Paisagens Inter e Subtropicais Brasileiras - Geomorfologia - nº 41 Instituto de Gegrafia. FFLCH / USP - São Paulo 1973.

- AB'SABER, Aziz N. - Os Domínios de Natureza no Brasil - Potencialidades Paisagísticas - Ateliê Editorial - São Paulo - 2003.

- ALMEIDA, Fernando Flávio M. - Fundamentos Geológicos do Relevo Paulista Geologia do Estão de São Paulo - Boletim no 41 Instituto Geográfico e Geológico São Paulo - 1964.

- ANDERSON, J. R. et al. - Trad Harold Strang - Sistema de Classificação do Uso da Terra e do Revestimento do Solo para Utilização com Dados de Sensores Remotos - Rio de Janeiro - IBGE - 1979.

- ASSAD, E. D. e SANO, E. E. - Sistemas de Informações Geográficas - Aplicados na Agricultura - EMBRAPA/CPAC - Brasília - 1998.

- AUDI, Raul - Classificação de solos em "Classes de Capacidade de Uso". Universidade de São Paulo - Instituto de Geografia - 1970. 
- AZEVEDO, Aroldo - Brasil a Terra e o Homem - Vol. I e II - Companhia Editora Nacional - São Paulo - 1968.

- BERNARDES, Nilo - A Geografia e o Planejamento Regional - Geografia e Planejamento nํ2 Instituto de Geografia - FFLCH / USP - São Paulo - 1969.

- BERTIN, J. - Sémiologie Graphique: lês diagrames, lês réseaux, lês cartes.- Paris $-1967$.

- BERTONI, J \& LONBARDI NETO, F. - Conservação do Solo - Piracicaba - SP Ícone - 1990.

- BIGARELLA, J. J. - Estrutura e origem das paisagens tropicais e subtropicais. Florianópolis - Editora da UFSC - vol. II - 1996p - 456-477.

- BIgARELLA, J. J. - Visão Integrada da Problemática da Erosão - Curitiba/Pr 1985.

- BITAR, Omar Yazbek - Curso de Geologia Aplicada ao Meio Ambiente. ABCGE IPT - Série Meio Ambiente - 1995 - 247p.

- BOULET, R. - Uma evolução recente da pedologia e suas implicações no conhecimento da gênese do relevo - In: Congresso ABEQUA 3 - Associação Brasileira de Estudos do Quaternário - Belo Horizonte - 1992 - p. 43-48.

- BRITO, Jorge L. S. - Adequação das Potencialidades do Uso da Terra na Bacia do Ribeirão Bom Jardim no Triângulo Mineiro/MG: Ensaio de Geoprocessamento Tese de Doutorado. Departamento de Geografia / FFLCH/ USP - São Paulo - 2001.

- CÂmara, G.; CASANOVA, M. A.; Hemerly, A. S.; MAgalhães, G. C. ; MEDEIROS, C. A. A. - Anatomia de Sistemas de Informação Geográfica CAMPINAS: UNICAMP/Instituto de Computação, 1996.

- CAMARGO, A. P., CHIARINI, J. V., DONZELI, P. L., SICHMANN, W. - Instituto Privado para Fomento de Oleaginosas Secretaria da Agricultura de Estado de São Paulo - 1971.

- CINTRA, J.P. - Automação da topografia: do campo ao projeto. São Paulo - 1993 120p. 
- CINTRA, J.P. - Informatização da carta de base do IGC - Rio de Janeiro: Sociedade Brasileira de Cartografia - 1995.

- CHIARINI, J.V. \& DONZELI, P.L. - Levantamento, por Fotointerpretação, das Classes de Capacidade de Uso das Terras do Estado de São Paulo - Secretaria da Agricultura - Instituto Agronômico do Estado de São Paulo - Campinas - 1973.

- CHRISTOFOLETTI, A. - Análise de Sistemas em Geografia - Hucitec - São Paulo $-1979-106$ pp.

- CHRISTOFOLETTI, A. - Introdução aos Sistemas de Informação Geográfica Edição do Autor - São Paulo - 1992 - 82 pp.

- COELHO, F. - Fertilidade do Solo -Instituto Campineiro de Ensino Agrícola Campinas - 1973.

- COELHO, A. G. de S. - Fotografias Aéreas Verticais na Classificação de Terras Agricultáveis - AEROFOTOGEOGRAFIA - oํ 6 Instituto de Geografia - FFLCH / USP. São Paulo - 1971.

- COMISSÃO DE SOLOS - Levantamento de Reconhecimento de Solos do Estado de São Paulo - Centro Nacional de Pesquisas Agronômicas - Boletim nº12 - Rio de Janeiro 1960.

- COMISSÃO DE ZONEAMENTO AGRÍCOLA - Zoneamento Agrícola do Estado de São Paulo - Vol. I. - Secretaria da Agricultura - São Paulo - 1974.

- CRÓSTA, A. P. - Processamento Digital de Imagens de Sensoriamento Remoto Campinas: UNICAMP/IG - 1992.

- DAEE - Secretaria de Recursos Hídricos Saneamento e Obras - Banco de Dados Pluviométricos do Estado de São Paulo - Atualizados até 1997 - Convênio DAEE I USP - São Paulo - 1997.

- DAEE - Secretaria de Recursos Hídricos Saneamento e Obras - Banco de Dados Fluviométricos do Estado de São Paulo - Atualizados até 1997 - Convênio DAEE I USP - São Paulo - 1997. 
- DE BIASE, Mário - Carta de Declividade de Vertentes - Confecção e Utilização Geomorfologia - no 21 Instituto de Geografia / USP. São Paulo - 1970.

- DE BIASI, Mário - A Carta Clinográfica - Revista do Dep. De Geografia da FFLCH-USP $n^{0} 6-1992$.

- DIRETORIA DE AGROPECUÁRIA E MEIO AMBIENTE DE PILAR DO SUL Informativo "O Agronegócio" - 2005.

- EMBRAPA - EPAMIG. - Levantamento de reconhecimento de média intensidade de solos e avaliação da aptidão agrícola das terras no Triangulo Mineiro. Boletim de Pesquisa nํ1 - Rio de Janeiro: EMBRAPA/SNLCS - 1982.

- EMBRAPA, SERVIÇO NACIONAL DE LEVANTAMENTO E CONSERVAÇÃO DE SOLOS - SNLCS - Manual de Métodos de Análise de Solo - Série miscelânea $n^{\circ} 4$ Rio de Janeiro: EMBRAPAVSLCS -1981.

- EMBRAPA, SERVIÇO NACIONAL DE LEVANTAMENTO E CONSERVAÇÃO DE SOLOS - SNLCS. Bases para Leitura de mapas de solos - Rio de Janeiro: EMBRAPA/SNLCS - 1979.

- EMBRAPA, SERVIÇO NACIONAL DE LEVANTAMENTO E CONSERVAÇÃO DE SOLOS - SNLCS - Critérios para distinção de classes de solos e fases de unidades de mapeamento: Normas de uso pelo SNLCS - Rio de Janeiro: EMBRAPA/SNLCS 1988.

- EMBRAPA - Sistema brasileiro de classificação de solos. Brasília: Produção de informação - 1999.

- FAHL, Joel Irinel et allii - Instruções Agrícolas para as Principais Culturas Econômicas - Instituto Agronômico - Boletim no 200 - 6 ${ }^{\mathrm{a}}$ Edição revisada e atualizada - Campinas - 1998.

- GALETI, P. - A Conservação de Solo Reflorestamento - Clima - Campinas, Instituto Campineiro Agrícola - 1989.

- GALIPI, D.B. - Metodologias para manutenção atualizada de bases cartográficas urbanas - São Paulo - 2002 - 140p. 
- GEORGE, P. - O meio ambiente - Saber Atual - Difusão Européia do Livro - São Paulo - 1973.

- GONÇALVES, Carlos Valter Porto. - Os (des)caminhos do meio ambiente. Contexto. São Paulo - 1989.

- GOVERNO FEDERAL - LEI nº 4771 - Código Florestal. Brasília, 15 de setembro de 1965.

- GOVERNO FEDERAL - Decreto Federal nº 22717 de 21/09/1984 - Área Tombada da Serra do Mar.

- INPE. SPRING: Manual do Usuário. São José dos Campos: INPE.

- INSTITUTO AGRONôMICO, Campinas - Boletim 200 - Instruções Agrícolas para as Principais Culturas Econômicas - Campinas - SP - 1998.

- INSTITUTO GEOGRÁFICO E CARTOGRÄFICO - Carta de Utilização da Terra do Estado de São Paulo - Plano Cartográfico do Estado de São Paulo - Escala 1:250.000 - 1981.

- IBGE - Atlas Nacional do Brasil - Rio de Janeiro: IBGE - 1996.

- IBGE - Diretoria de Geociências - Mapas de Solos do Brasil - Rio de Janeiro: Instituto Brasileiro de Geografia e Estatística - 2001.

- IBGE - Recursos Naturais e Meio Ambiente: Uma Visão do Brasil - Rio de janeiro 1993.

- JOLY, F.- A Cartografia - Tradução Pellegrini, T. - Campinas, SP: Papirus-1990.

- JOLY, F. - La Cartografia. Ariel, Barcelona - 1982.

- KELLER, Elza Coelho de Souza - Aerogeografia nํㅜ 3 - Instituto de Geografia USP -1969.

- LA CORTE, Judith de - Contribuição ao Estudo do Abastecimento da Cidade de São Paulo em Produtos Hortifrutícolas - Tese de Doutorado. Instituto de Geografia USP, Série Teses e Monografias nํㅜ 31 - São Paulo - 1985. 
- LEPSCH, I. F.;BELLINAZZI JR.,R. ;BERTOLINI, D. ; ESPÍNDOLA, C. R. - Manual para Levantamento Utilitário do Meio Físico e Classificação de Terras no Sistema de Capacidade de Uso ( $4^{\mathrm{a}}$. aproximação ). Campinas : Sociedade Brasileira de Ciência do Solo - 1983.

- LEPSCH, I. F. - Formação e Conservação dos Solos - São Paulo: Oficina de Textos - 2002.

- LIBAULT, Charles O. A. - Os Quatro Níveis da Pesquisa Geográfica. Métodos em questão. São Paulo. Instituto de Geografia / USP - São Paulo - 1971.

- MANZATTO, C. V.; BHERING, S. B. \& SIMÕES, M. - Agricultura de Precisão: Propostas e Ações da EMBRAPA Solos.

- MARTINELLI, M. - Curso de Cartografia Temática - São Paulo: Contexto -1991.

- MARQUES MOACYR - Geografia e Planejamento - ํํ 20 Instituto de Geografia USP - 1975.

- MAURO, Claudio Antonio de; Leal Antonio Cezar - Meio Ambiente e Urbanização na Microbacia do Areia Branca. - Campinas - SP. Mestrado Rio Claro - Unesp 1995.

- MEZZALIRA, Sérgio (organ) - Léxico Estratigráfico do Estado de São Paulo. Instituto Geológico. Boletim nº 5 - São Paulo - 1981.

- MERLIN, P. - A Topografia - Tradução de Sousa, G.G. - São Paulo - 1965.

- MONTEIRO, Carlos Augusto de Figueiredo - A Dinâmica Climática e as Chuvas no Estado de São Paulo - Instituto de Geografia / USP -São Paulo - 1973.

- NOVO, Evlyn M. L. de Moraes - Sensoriamento Remoto - Princípios e Aplicações

- Edgard Blücher - São Paulo - 1988.

- OLIVEIRA Gabriel Mauro de Araujo - Caderno de Ciências da Terra - ํㅡ 46 Instituto de Geografia - USP - 1974.

- PRIMACK, R. B. - Biologia da Conservação - E. Rodrigues - 2001.

- RAISZ, E. - Cartografia General - Barcelona - 1974. 
- PINTO, H. S; ORTOLANI, A.A. \& ALFONSI, R.R. - Estimativa das Temperaturas Médias Mensais do Estado de São Paulo em Função da Altitude e Latitude. Caderno de Ciências da Terra - no 23 Instituto de Geografia - FFLCH / USP - São Paulo - 1972.

- PROJETO RADAMBRASIL - Mapa Geomorfológico - Folha Rio de Janeiro / Vitória - Escala 1:1000000 / Vol. 32 - Ministério de Minas e Energia - 1983.

- QUIEROZ NETO, J. P. de - Departamento de Geografia, USP - Ánálise Estrutural da Cobertura Pedológica Aplicada à Elaboração de Cartas Geotécnicas e de Capacidade de Uso das Terras.

- QUEIROZ NETO, J. P. - Pedogênese no Planalto Atlântico: contribuição a interpretação paleogeográfica dos solos da Mantiqueira Ocidental - São Paulo FFLCH - Dep. Geogr. (tese de Livre Docência).

- QUEIROZ NETO, J. P. - Análise estrutural da cobertura pedológica no Brasil - In: Congresso Brasileiro de Ciências do Solo, XXI - Campinas - Sociedade Brasileira de Ciência do Solo - 1987 - p. 415-429.

- ROSA, F.S. - Metrópole e Representação Cartográfica: O Sistema Cartográfico Metropolitano de São Paulo - Tese de Doutorado - FFLCH - USP - 1989.

- ROSA, F.S. - Impactos da Informática na Cartografia - Geodigital 1996 - Anais Simpósio Internacional sobre Novas Tecnologias Digitais em Geografia e Cartografia: Aplicações no Ensino e Planejamento Ambiental. Departamento de Geografia, FFLCH - USP - 1996. pg. $34-40$.

- ROSS, J. L. S. - Geomorfologia, Ambiente e Planejamento - Editora Contexto, São Paulo - 1990.

- ROSS, J.L.S. - O Registro Cartográfico dos Fatos Geomórficos e a Questão da Taxonomia do Relevo - in rev. Depto Geografia- no 6 -FFLCH - USP - São Paulo 1992.

- ROSS, J. L. S., MORAES, P. B. L. de, SIMÕES, W. et alli - Abordagem Geográfica do Planejamento Ambiental - 1993. 
- ROSS, J.L.S. - Análise Empírica da Fragilidade dos Ambientes Naturais e Antropizados - in Rev. Depto. Geografia - no 8 - FFLCH USP - São Paulo - 1994.

- ROSS, J. L. S et al. - Geografia do Brasil - Editora da Universidade de São Paulo $-1995$.

- ROSS, J. L. S - Análises e Sínteses na Abordagem Geográfica da Pesquisa para o Planejamento Ambiental - Revista do Departamento de Geografia - USP - FFLCH $-1995$.

- ROSS, J.L.S. - Geomorfologia Aplicada aos EIAS-RIMAS - in Geomorfologia e Meio Ambiente - Bertrand - Brasil Rio de janeiro - 1995.

- ROSS, J. L. S. \& MOROZ, I. C. - Mapa Geomorfológico do Estado de São Paulo Laboratório de Geomorfologia - Departamento de Geografia - FFLCH - USP / IPT / FAPESP - 1997.

- ROSS, J.L.S. - Análises e Sínteses na Abordagem Geográfica para o Planejamento Ambiental - in Rev. do Departamento de Geografia nํ9 - FFLCH-USPSão Paulo - 1991.

- ROSSI, M. \& QUEIROZ NETO, J. P. - Relação solo/paisagem em regiões tropicais úmidas: o exemplo da Serra do Mar em São Paulo/Brasil. Revista do Departamento de Geografia nํㅜ 14 - 2001 - p.11-23.

- SAGRES - Geoprocessamento Municipal - Curitiba/Pr - 1994.

- SANTOS, Elina O. - A Industrialização de Sorocaba - Bases Geográficas - Série Teses - Humanitas - FFLCH / USP - São Paulo - 1999.

- SANTIAGO, L.A. - Proposta metodológica para digitalização de mapas cartográficos: um plano para a carta de base do IGC - São Paulo - 1999 -193p.

- SÃO PAULO Secretaria de Economia e Planejamento - Coordenadoria de Ação Regional - Atlas Regional do Estado de São Paulo - Sorocaba - São Paulo - 1978.

- SÃO PAULO Secretaria de Agricultura e Abastecimento - Instituto de Economia Agrícola - Coordenadoria de Assistência Técnica Integral - Previsões e Estimativas das Safras Agrícolas - Ano Agrícola - 2004/05. 
- SETZER, José - Os Solos do Estado de São Paulo - Instituto Brasileiro de Geografia e Estatística / CNG. Rio de Janeiro - 1949.

- SIMIELLI, M. E. R. - Variação Espacial da Capacidade de Uso da Terra - Um Ensaio metodológico de cartografia temática, aplicado ao município de Jundiaí SP.- IGEOG - USP - Série Teses e Monografias nº 41 - São Paulo - 1981.

- SILVIA, W. S., FILHO, N. F. - Unidades de Conservação Ambiental e Áreas Correlatas no Estado de São Paulo - Instituto de Pesquisas Tecnológicas - 1992. (Publicações IPT; 1978)

- STAR, J. \& ESTES, J. - Geographic Information System. An Introduction. Prentice Hall - New Jersey.

- STEIN, D. P.; DONZELI, P. L.; GIMENEZ, A. F., PONÇANO, W. L.; LOMBARDI NETO, F. - Potencial de Erosão Laminar, Natural e Antrópico na Bacia do Peixe Paranapanema.

- SUPLAN - Secretaria Nacional de Planejamento Agrícola - Aptidão Agrícola das Terras. Estado de São Paulo - Escala 1:1.000.000 - 1979.

- TeIXEIRA, A.L.A., MORETTI, E., CHRISTOfOletTI A. - Introdução aos Sistemas de Informações Geográficas - Rio Claro - 1992.

- TEIXEIRA, A. L. A. \& CHRISTOFOletTI, A. - Sistemas de Informação Geográfica. Dicionário llustrado - Hucitec - São Paulo, 1997.

- TEIXEIRA GUERRA, A. J. et al. - Erosão e Conservação dos Solos: Conceitos, Temas e Aplicações - Rio de Janeiro - Bertrand Brasil - 1999.

- TEIXEIRA GUERRA, A. J. et al. - Geomorfologia e Meio Ambiente - Rio de Janeiro: Bertrand Brasil - 2003.

- TOSÍ, Francisco de A. - Sistemas de Informações Geográficas na Agricultura.

- TOledo, M. C. M.; OliVEIRA, S. M. B. de; MELFI, A. J. \& CARVALHO, A. Intemperismo e Formação do Solo - In: Teixeira, W. (Org.). Decifrando a Terra. São Paulo: Oficina de textos - 2000 - p. 140-166.

- TRICART, J. - O conceito Ecológico in Ecodinâmica. FIBGE- Rio de Janeiro -1977. 
- TRICART, J. - Classificação Ecodinâmica do meio ambiente, in ecodinâmica FIBGE - Rio de Janeiro - 1977.

- TROPPMAIR, Helmut - Regiões Ecológicas do Estado de São Paulo Biogeografia - nº 10 Instituto de Geografia FFLCH / USP. São Paulo - 1975.

- VIDAL TORRADO, P.; LePSCH, I. F.; CASTRO, S. S.; \& COOPER, M. Pedogênese em uma seqüência Latossolo-Podzólico na borda de um platô na Depressão Periférica Paulista - Revista Brasileira de Ciência do Solo ${ }^{0} 23(4)$ 1999 - p. 909-921.

- WERLANG, Mauro K. - Capacidade de Uso da Terra na Bacia Hidrográfica do Rio Arareau - Rondonópolis - MT - Dissertação de Mestrado - Departamento de Geografia / FFLCH / USP - São Paulo - 1997.

- ZACHARIAS, A. A. - Metodologias Convencionais e Digitais para a Elaboração de Cartas Morfométricas do Relevo - Dissertação de Mestrado - Instituto de Geociências e Ciências Exatas - UNESP. Rio Claro - 2001.

- Zingg, R. W. - Degree and length of land slope as it affects soil loss in runoff Agricultural Engineering - nํㅜ 21 - 1940 - p.59-64. 